\title{
SUPRESSÃO DA INFESTAÇÃO DE PLANTAS DANINHAS PELO SISTEMA DE PRODUÇÃO DE INTEGRAÇÃO LAVOURA-PECUÁRIA
}

\section{FRANCISCO JOSÉ SEVERINO}

Tese apresentada à Escola Superior de Agricultura "Luiz de Queiroz", Universidade de São Paulo para obtenção do título de Doutor em Agronomia, Área de Concentração: Fitotecnia.

P I R A C I C A B A

Estado de São Paulo - Brasil

Maio - 2005 


\section{SUPRESSÃO DA INFESTAÇÃO DE PLANTAS DANINHAS PELO SISTEMA DE PRODUÇÃO DE INTEGRAÇÃO LAVOURA-PECUÁRIA}

\section{FRANCISCO JOSÉ SEVERINO}

Engenheiro Agrônomo

Orientador: Prof. Dr. PEDRO JACOB CHRISTOFFOLETI

Tese apresentada à Escola Superior de Agricultura "Luiz de Queiroz", Universidade de São Paulo para obtenção do título de Doutor em Agronomia, Área de Concentração: Fitotecnia.

P I R A C I C A B A

Estado de São Paulo - Brasil

Maio - 2005 
Dados Internacionais de Catalogação na Publicação (CIP) DIVISÃO DE BIBLIOTECA E DOCUMENTAÇÃO - ESALQ/USP

\section{Severino, Francisco José}

Supressão da infestação de plantas daninhas pelo sistema de produção de integração lavoura-pecuária / Francisco José Severino. - - Piracicaba, 2005. $113 \mathrm{p}$.

Tese (doutorado) - - Escola Superior de Agricultura Luiz de Queiroz, 2005. Bibliografia.

1. Consorciação de cultura 2. Lavoura 3. Manejo integrado 4. Milho 5. Pastagem cultivada 6. Pecuária 7. Planta daninha 8. Planta forrageira 9. Recuperação do solo I. Título

CDD 633.2

\section{"Permitida a cópia total ou parcial deste documento, desde que citada a fonte - 0 autor"}




\section{Dedico,}

À minha esposa Sandra, pelo amor e companheirismo;

Aos meus filhos, Gabriel e Lucas, pela nobreza de corações;

Ao meu orientador, Prof. Dr. Pedro Jacob Christoffoleti, pela amizade e por acreditar na minha proposta de trabalho.

\section{Ofereço,}

Às futuras gerações, desejando que respeitem os interesses de todos e protejam a integridade do sistema global de ecologia e desenvolvimento. 


\section{AGRADECIMENTOS}

À Deus, pela vida;

Ao Prof. Dr. Pedro Jacob Christoffoleti pela amizade e dedicação;

À Comissão do Programa de Pós-graduação em Fitotecnia da ESALQ-USP, pela oportunidade de realização do Curso;

Aos Professores Dr. Ricardo Victoria Filho e Dr. Durval Dourado Neto pelo apoio e amizade constantes;

Aos funcionários da Área de Biologia e Manejo de Plantas Daninhas, Luiz Ferrari e Aparecido Mendes, pelo auxílio e amizade durante todo o desenvolvimento dos trabalhos;

Às secretárias do Departamento de Produção Vegetal da USP/ESALQ, Luciane, Elizabete e Célia e à Helena, pela amizade e dedicação;

À CAPES pelo suporte financeiro;

E, a todos que contribuíram direta ou indiretamente para a realização desse trabalho.

"Nossa busca de descobertas alimenta nossa criatividade em todos os campos, não apenas na ciência. Se chegássemos ao fim da linha, o espírito humano definharia e morreria. Mas não creio que um dia sossegaremos: aumentaremos em complexidade, se não em profundidade, e seremos sempre o centro de um horizonte de possibilidades em expansão".

(Stephen Hawking, 2001) 


\section{SUMÁRIO}

Página

LISTA DE FIGURAS...................................................................................... vii

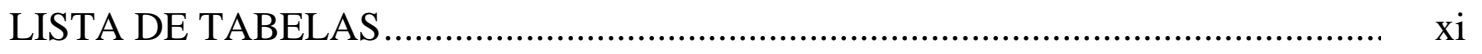

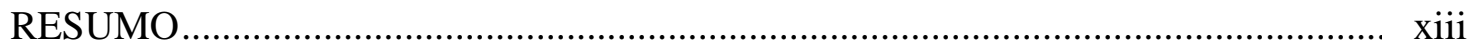

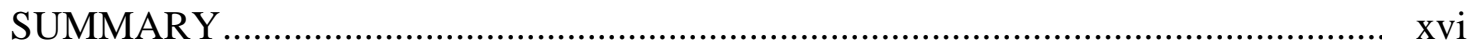

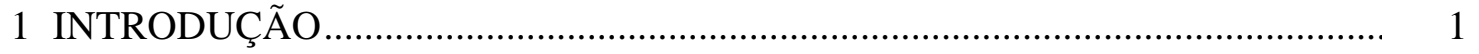

2 REVISÃO DE LITERATURA …………........................................................ 4

2.1 Cobertura vegetal do solo: considerações gerais ................................................... 4

2.2 Cobertura vegetal do solo na cultura de milho ..................................................... 8

2.3 Controle de plantas daninhas pela cobertura vegetal do solo na cultura de milho

2.4 Controle do crescimento das plantas utilizadas como cobertura vegetal do solo.

2.5 Dinâmica do banco de sementes de plantas daninhas na cultura de milho........... 14

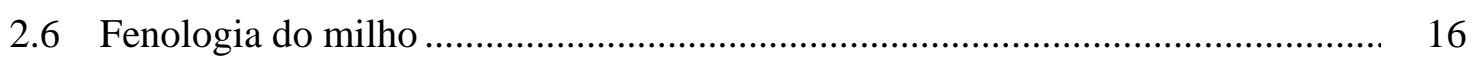

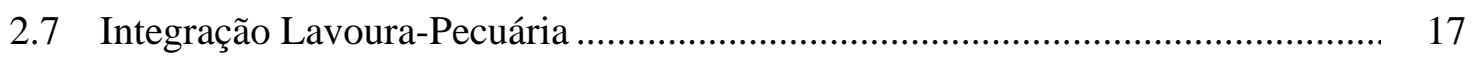

2.8 Medidas de interferências de plantas forrageiras consorciadas com a cultura

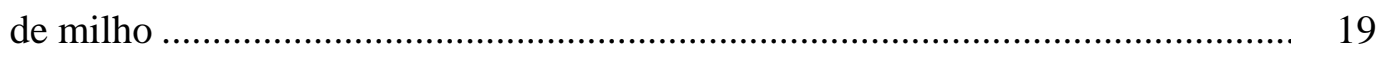

2.8.1 Competição ............................................................................................... 19

2.8.1.1 Competição por água ............................................................................ 21

2.8.1.2 Competição por luz..................................................................................... 22

2.8.1.3 Competição por nutrientes ........................................................................... 25

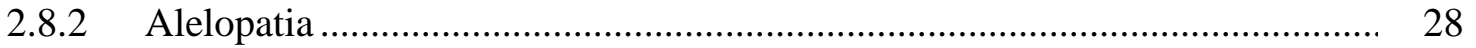


2.8.2.1 Efeitos da alelopatia na consorciação

2.9 Importância, histórico e descrição das plantas forrageiras utilizadas na experimentação 30

2.9.1 Importância e histórico de gramíneas e leguminosas........................................ 30

2.9.2 Brachiaria brizantha (Hochst. ex A. Rich.) Stapf. .......................................... 31

2.9.3 Brachiaria decumbens Stapf. Prain.............................................................. 32

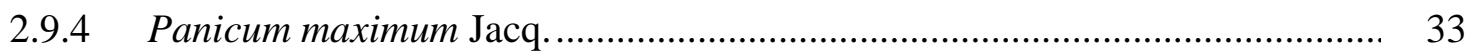

2.10 Importância, histórico e descrição das plantas daninhas utilizadas na experimentação............................................................................................ 35

2.10.1 Ipomoea grandifolia (Dammer) O’Don .......................................................... 35

2.10.2 Amaranthus hybridus L........................................................................... 37

2.10.3 Digitaria horizontalis Willd................................................................... 38

3 MATERIAL E MÉTODOS .............................................................................. 40

3.1 Experimento de campo ..................................................................................... 40

3.2 Experimento em casa-de-vegetação.................................................................. 46

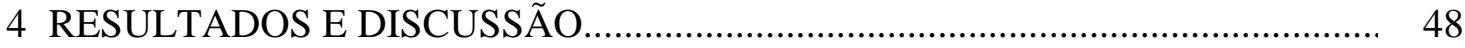

4.1 Experimento de campo ................................................................................ 48

4.2 Experimento em casa-de-vegetação................................................................ 76

4.3 Considerações gerais sobre a pesquisa …..................................................... 88

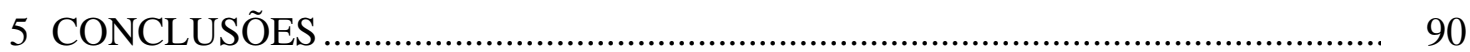

REFERÊNCIAS BIBLIOGRÁFICAS ……………............................................ 92 


\section{LISTA DE FIGURAS}

Página

1 Acúmulo de massa seca (g) por planta da planta daninha corda-de-viola (Ipomoea grandifolia - IAQGR) quando na presença da cultura do milho e de diferentes culturas forrageiras e IAQGR - sem a presença das culturas (testemunha D).

2 Acúmulo de massa seca (g) por planta da planta daninha caruru (Amaranthus hybridus - AMACH) quando na presença da cultura do milho e de diferentes culturas forrageiras e AMACH - sem a presença das culturas (testemunha D)... 59

3 Acúmulo de massa seca (g) por planta da planta daninha capim-colchão (Digitaria horizontalis - DIGHO) quando na presença da cultura do milho e de diferentes culturas forrageiras e DIGHO - sem a presença das culturas (testemunha D)

4 Acúmulo de área foliar $\left(\mathrm{cm}^{2}\right)$ por planta da planta daninha corda-de-viola (Ipomoea grandifolia - IAQGR) quando na presença da cultura do milho e de diferentes culturas forrageiras e IAQGR - sem a presença das culturas (testemunha D).

5 Acúmulo de área foliar $\left(\mathrm{cm}^{2}\right)$ por planta da planta daninha caruru (Amaranthus hybridus - AMACH) quando na presença da cultura do milho e de diferentes culturas forrageiras e AMACH - sem a presença das culturas (testemunha D)

6 Acúmulo de área foliar $\left(\mathrm{cm}^{2}\right)$ por planta da planta daninha capim-colchão Digitaria horizontalis - DIGHO) quando na presença da cultura do milho e de diferentes culturas forrageiras e DIGHO - sem a presença das culturas 
(testemunha D)

65

7 Acúmulo de massa seca (g) por perfilho da planta forrageira $B$. decumbens quando na presença da cultura do milho e de diferentes plantas daninhas e BRADC - sem a presença da cultura do milho e das plantas daninhas (testemunha C)

8 Acúmulo de massa seca (g) por perfilho da planta forrageira B. brizantha quando na presença da cultura do milho e de diferentes plantas daninhas e BRABR - sem a presença da cultura do milho e das plantas daninhas (testemunha C)

9 Acúmulo de massa seca (g) por perfilho da planta forrageira P. maximum quando na presença da cultura do milho e de diferentes plantas daninhas e PANMA - sem a presença da cultura do milho e das plantas daninhas (testemunha C)

10 Acúmulo de área foliar $\left(\mathrm{cm}^{2}\right)$ por perfilho da planta forrageira B. decumbens quando na presença da cultura do milho e de diferentes plantas daninhas e BRADC - sem a presença da cultura do milho e das plantas daninhas (testemunha C)

11 Acúmulo de área foliar $\left(\mathrm{cm}^{2}\right)$ por perfilho da planta forrageira $B$. brizantha quando na presença da cultura do milho e de diferentes plantas daninhas e BRABR - sem a presença da cultura do milho e das plantas daninhas (testemunha C)

12 Acúmulo de área foliar $\left(\mathrm{cm}^{2}\right)$ por perfilho da planta forrageira P. maximum quando na presença da cultura do milho e de diferentes plantas daninhas e PANMA - sem a presença da cultura do milho e das plantas daninhas (testemunha C)

13 Acúmulo da massa seca (g) por planta da cultura do milho quando na presença da planta daninha I. grandifolia e de diferentes culturas forrageiras e IAQGR - com a presença somente da planta daninha e testemunha A do 
milho solteiro e capinado

14 Acúmulo da massa seca (g) por planta da cultura do milho quando na presença da planta daninha $A$. hybridus e de diferentes culturas forrageiras e AMACH - com a presença somente da planta daninha e testemunha A do milho solteiro e capinado

15 Acúmulo da massa seca (g) por planta da cultura do milho quando na presença da planta daninha $D$. horizontalis e de diferentes culturas forrageiras e DIGHO - com a presença somente da planta daninha e testemunha A do milho solteiro e capinado.

16 Acúmulo da massa seca (g) por planta da cultura do milho quando na presença da planta forrageira $B$. decumbens e de diferentes plantas daninhas e sem a presença das culturas forrageiras e das plantas daninhas (testemunha A)..

17 Acúmulo da massa seca (g) por planta da cultura do milho quando na presença da planta forrageira $B$. brizantha e de diferentes plantas daninhas e sem a presença das culturas forrageiras e das plantas daninhas (testemunha A).. 78

18 Acúmulo da massa seca (g) por planta da cultura do milho quando na presença da planta forrageira P. maximum e de diferentes plantas daninhas e sem a presença das culturas forrageiras e das plantas daninhas (testemunha A).. 79

19 Acúmulo da massa seca (g) por planta da cultura do milho solteiro (sem as culturas forrageiras, porém na presença das diferentes plantas daninhas e testemunha A onde a cultura do milho foi cultivada sem competição (capinada)

20 Acúmulo de área foliar $\left(\mathrm{cm}^{2}\right)$ por planta da cultura do milho quando na presença da planta daninha I. grandifolia e de diferentes culturas forrageiras e IAQGR - sem a presença das culturas forrageiras e testemunha A do milho solteiro

21 Acúmulo de área foliar $\left(\mathrm{cm}^{2}\right)$ por planta da cultura do milho quando na presença da planta daninha $A$. hybridus e de diferentes culturas forrageiras e 
AMACH - sem a presença das culturas forrageiras e testemunha A do milho solteiro

22 Acúmulo de área foliar $\left(\mathrm{cm}^{2}\right)$ por planta da cultura do milho quando na presença da planta daninha $D$. horizontalis e de diferentes culturas forrageiras e DIGHO - sem a presença das culturas forrageiras e testemunha A do milho solteiro

23 Acúmulo de área foliar $\left(\mathrm{cm}^{2}\right)$ por planta da cultura do milho quando na presença da planta forrageira $B$. decumbens e de diferentes plantas daninhas e sem a presença da cultura forrageira (testemunha A).

24 Acúmulo de área foliar $\left(\mathrm{cm}^{2}\right)$ por planta da cultura do milho quando na presença da planta forrageira B. brizantha e de diferentes plantas daninhas e

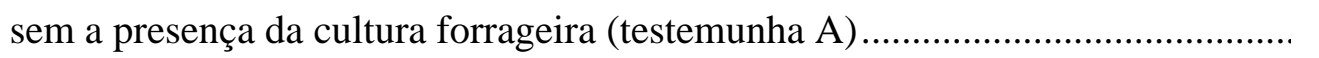

25 Acúmulo de área foliar $\left(\mathrm{cm}^{2}\right)$ por planta da cultura do milho quando na presença da planta forrageira $P$. maximum e de diferentes plantas daninhas e sem a presença da cultura forrageira (testemunha A).

26 Acúmulo de área foliar $\left(\mathrm{cm}^{2}\right)$ por planta da cultura do milho solteiro (sem as culturas forrageiras), porém na presença das plantas daninhas e testemunha A onde a cultura do milho foi cultivada sem competição (capinada) 


\section{LISTA DE TABELAS}

Página

1 Resultados da análise química do solo da área experimental do experimento de campo, Piracicaba, SP

2 Dados climatológicos relativos ao período de condução do experimento de campo (dezembro de 2003 a maio de 2004), Piracicaba, SP

3 Rendimento do milho em grãos (ton.ha ${ }^{-1}$ ) na interação de tratamentos com culturas forrageiras e plantas daninhas, aos 150 dias após a instalação do experimento. Piracicaba, ESALQ/USP, maio de 2004.

4 Produção de massa verde das plantas forrageiras (ton.ha-1) na interação de tratamentos com culturas forrageiras e plantas daninhas, aos 160 dias após a instalação do experimento. Piracicaba, ESALQ/USP, maio de 2004.

5 Infestação de plantas daninhas (plantas $/ \mathrm{m}^{-2}$ ) na interação de tratamentos com culturas forrageiras e plantas daninhas, aos 30 dias após a instalação do experimento. Piracicaba, ESALQ/USP, maio de 2004.

6 Infestação de plantas daninhas (plantas $/ \mathrm{m}^{-2}$ ) na interação de tratamentos com culturas forrageiras e plantas daninhas, aos 60 dias após a instalação do experimento. Piracicaba, ESALQ/USP, maio de 2004.

7 Parâmetros do modelo logístico para a variável acúmulo de massa seca (g) durante o crescimento das plantas daninhas na presença da cultura do milho e das diferentes culturas forrageiras utilizadas no experimento e na testemunha ... 56 
8 Parâmetros do modelo logístico para a variável acúmulo de área foliar $\left(\mathrm{cm}^{2}\right)$ durante o crescimento das plantas daninhas na presença da cultura do milho e das diferentes culturas forrageiras utilizadas no experimento e na testemunha ...

9 Parâmetros do modelo logístico para a variável acúmulo de massa seca (g) por perfilho das culturas forrageiras na presença da cultura do milho e das diferentes plantas daninhas utilizadas no experimento e sem a presença da cultura de milho e das plantas daninhas (testemunha)

10 Parâmetros do modelo logístico para a variável acúmulo de área foliar $\left(\mathrm{cm}^{2}\right)$ por perfilho das culturas forrageiras na presença da cultura do milho e das diferentes plantas daninhas utilizadas no experimento e sem a presença da cultura de milho e das plantas daninhas (testemunha)

11 Parâmetros do modelo logístico para a variável acúmulo de massa seca (g) durante o crescimento das plantas de milho quando na presença de diferentes culturas forrageiras e plantas daninhas, com a presença somente das plantas daninhas e milho solteiro (testemunhas).

12 Parâmetros do modelo logístico para a variável acúmulo de área foliar $\left(\mathrm{cm}^{2}\right)$ durante o crescimento das plantas de milho quando na presença de diferentes culturas forrageiras e plantas daninhas, com a presença somente das plantas daninhas e milho solteiro (testemunhas).

13 Número de plantas daninhas emergidas (plantas/bandeja ${ }^{-1}$ ) em solo cultivado com culturas forrageiras consorciadas com a cultura de milho, aos 30 dias após a instalação do experimento em casa-de-vegetação. Piracicaba, ESALQ/USP, junho e julho de 2004 ....

14 Número de plantas daninhas emergidas (plantas/bandeja ${ }^{-1}$ ) em solo cultivado com culturas forrageiras consorciadas com a cultura de milho, aos 60 dias após a instalação do experimento em casa-de-vegetação. Piracicaba, ESALQ/USP, junho e julho de 2004 


\title{
SUPRESSÃO DA INFESTAÇÃO DE PLANTAS DANINHAS PELO SISTEMA DE PRODUÇÃO DE INTEGRAÇÃO LAVOURA-PECUÁRIA
}

\author{
Autor: FRANCISCO JOSÉ SEVERINO
}

Orientador: Prof. Dr. PEDRO JACOB CHRISTOFFOLETI

\section{RESUMO}

A consorciação de cultivos com diferentes espécies vegetais tem se constituído em uma prática agrícola usual em sistemas de produção conservacionistas, que dentre as vantagens de sua utilização destaca-se o manejo integrado de plantas daninhas. Entretanto, a ampla utilização destes sistemas de produção na atualidade tem exigido o desenvolvimento de pesquisas relativas ao crescimento e desenvolvimento das plantas cultivadas em convivência, bem como seus efeitos na comunidade infestante do local. A integração entre culturas anuais e pastagens cultivadas simultaneamente em uma área tem surgido como um sistema de produção alternativo para a recuperação de solos degradados pela atividade agropecuária intensiva; no entanto, existem ainda alguns questionamentos científicos e práticos sobre o manejo das plantas daninhas no sistema, e a relação com a produtividade das culturas em convivência simultânea. Desta forma, o objetivo desta pesquisa foi de avaliar a influência de três culturas forrageiras (Brachiaria 
decumbens, Brachiaria brizantha e Panicum maximum) consorciadas à cultura do milho (Zea mays), através do sistema de produção de integração lavoura-pecuária sobre: (i) infestação e banco de sementes de três espécies de plantas daninhas (Ipomoea grandifolia, Amaranthus hybridus e Digitaria horizontalis) em convivência; (ii) produção final de matéria verde das culturas forrageiras; (iii) rendimento de grãos da cultura do milho; (iv) curvas de crescimento das plantas de milho e perfilhos das forrageiras e das plantas daninhas estudadas. Os experimentos foram desenvolvidos em área experimental do Departamento de Produção Vegetal da Escola Superior de Agricultura “Luiz de Queiroz”, Universidade de São Paulo, no município de PiracicabaSP. O delineamento experimental utilizado no ensaio de campo foi o de blocos casualizados, em parcelas subdivididas, e o experimento realizado em casa-de-vegetação foi em esquema fatorial. Os parâmetros avaliados no experimento de campo foram os seguintes: densidade plantas daninhas (plantas. $\mathrm{m}^{-2}$ ); área foliar por planta ou perfilho $\left(\mathrm{cm}^{2}\right)$ e biomassa seca por planta ou perfilho (g) das culturas de milho e forrageiras e das plantas daninhas; biomassa verde das culturas forrageiras (ton.ha ${ }^{-1}$ ) e rendimento de grãos da cultura do milho (ton.ha ${ }^{-1}$ ). Em casa-de-vegetação foi avaliada a emergência do banco de sementes, à partir de amostras de solo coletadas nas áreas respectivas dos tratamentos implantados no experimento de campo. Os resultados permitiram concluir que o emprego do sistema de produção lavoura-pecuária contribui, significativamente, para a redução da infestação das plantas daninhas testadas, auxiliando de maneira sustentável, no manejo integrado de plantas daninhas, sendo que as infestações são suprimidas de forma diferenciada pelas plantas forrageiras. Conclui-se ainda que, houve redução diferenciada do banco de sementes das plantas daninhas pelas forrageiras, bem como redução no rendimento de grãos da cultura do milho e das culturas forrageiras neste sistema de produção, quando comparado com os monocultivos. Entretanto, como conclusão geral, a pesquisa demonstrou a viabilidade técnica da utilização do sistema de produção que integra lavoura e pecuária, cujo manejo de plantas daninhas é realizado de forma cultural, sem a utilização de herbicidas, contribuindo assim para a redução de 
possíveis impactos ambientais causados pela utilização de produtos químicos na agricultura. 


\title{
WEED INFESTATIONS SUPPRESSION BY THE CROPPING SYSTEM OF INTEGRATION OF CROP-CATTLE PRODUCTION
}

\author{
Author: FRANCISCO JOSÉ SEVERINO \\ Adviser: Prof. Dr. PEDRO JACOB CHRISTOFFOLLETI
}

\section{SUMMARY}

The intercropping system with different vegetable species has become a common agricultural practice in conservationist production systems, that among the advantages of its use, it can be obtained the integrated weed management. However, the wide use of these cropping systems nowadays has required the development of researches related to growth and development of cultivated plants in coexistence, as well as to the local weed community infestation. The integration among annual crops and pastures grown simultaneously in an area has become as an alternative cropping system for the recovery of degraded soils by the intensive use for cattle grazing; however, there are still some scientific and practical questioning about this cropping system about weed management in the system, and the relation with crop yields grown in coexistence. Therefore, this research had the objective of evaluating the influence of integration of three grass forage crops (Brachiaria decumbens, Brachiaria brizantha and Panicum maximum) intercropped with corn (Zea mays) crop on: (i) infestation and seed bank of three weed 
species (Ipomoea grandifolia, Amaranthus hybridus and Digitaria horizontalis); (ii) final biomass of the forage crops; (iii) corn grain yields; (iv) growth curves of corn plants, forage tillers and weed plants studied. The experiments were developed in the experimental area of the Crop Production Department of Escola Superior de Agricultura “Luiz de Queiroz”, University of São Paulo - Brazil. The experimental design used in the field experiment was randomized complete blocks, with split plots, and the experiment in the greenhouse was in a factorial design. The evaluated parameters for the field experiment were: weed density (plants. $\left.\mathrm{m}^{-2}\right)$; leaf area per plant or tillers $\left(\mathrm{cm}^{2}\right)$ and dry biomass yield per plant or tillers (g) of corn and forage crops and weeds, and green biomass of the forage crops (ton.ha ${ }^{-1}$ ) and corn grain yield (ton.ha ${ }^{-1}$ ). In the greenhouse it was evaluated the weed emergence of the soil seed bank, from samples collected of the plots in the field experiment. The results allowed concluding that the use of the system crop - cattle production contributes significantly in the reduction of the infestation of the studied weeds, helping in a sustainable way the integrated weed management, being the weed infestations suppressed in different intensities by the forage crops tested. Furthermore, it also can be concluded that there was as reduction in the weed soil seed bank in different intensity by the forage crops, as well as, the reduction in the corn grain yield and forage green biomass in the system, when compared with the monocrops. However, the general conclusion is that the research showed technical viability of integration crop and forage production systems, which weed management is done a cultural way, without the use of herbicide, therefore contributing for the reduction in the possible environmental impacts caused by the utilization of chemical products in the agriculture. 


\section{INTRODUÇÃO}

A cultura do milho (Zea mays L.) é uma das principais cultivadas no mundo, fornecendo produtos amplamente utilizados para a alimentação humana e de animais e matérias-primas para a indústria, notadamente em função da quantidade e da natureza das reservas acumuladas nos grãos (Bastos, 1987; Cavalcanti, 1987; Andrade, 2000; Fancelli \& Dourado Neto, 2000 e 2001).

Cultivo dos mais tradicionais, assumindo importante papel sócio-econômico, encontra-se em posições de relevância no que se refere ao valor da produção agropecuária, área plantada e volume produzido, em especial nas regiões Sul, Sudeste e Centro-Oeste do Brasil. Entretanto, apesar da evolução gradativa ocorrida nas quantidades produzidas, a produção de grãos por unidade de área ainda não expressa o potencial genético dos materiais recomendados pela pesquisa (Andrade, 2000; Fancelli \& Dourado Neto, 2000 e 2001).

Desta forma, em função dos diferentes níveis tecnológicos empregados nesta cultura e da diversidade de condições edafoclimáticas encontradas no Brasil, os rendimentos médios de grãos têm sido relativamente baixos nos últimos anos (Ferreira, 1996). Por outro lado, essa defasagem entre os rendimentos potenciais e os observados em condições de campo, pode ser atribuída a vários fatores, inclusive os de ordem econômica, sendo que, seguramente, os diversos níveis de tecnologia adotados por boa parte dos produtores não correspondem às exigências dos cultivares selecionados para a semeadura.

Assim sendo, dentre os fatores bióticos responsáveis pela redução de rendimento das culturas encontram-se as interferências negativas causadas pela infestação de plantas 
daninhas, que podem afetar a produção econômica, em função, principalmente, da competição por água, nutrientes, luz e possíveis efeitos alelopáticos, bem como por serem hospedeiras de pragas, agentes causadores de doenças e nematóides, dificultar a operação de colheita ou mesmo depreciar a qualidade final do produto (Durigan, 1988; Christoffoleti, 1988). Desta maneira, a interferência das plantas daninhas em coexistência com as culturas é importante fator que afeta a economia agrícola, em caráter permanente. Portanto, se por um lado a sua presença na cultura ocasiona prejuízos inquestionáveis devido às diversas formas de interferência, por outro o seu controle ainda acarreta, na maioria das vezes, um aumento significativo no custo de produção (Christoffoleti, 1988).

Atualmente, o controle de plantas daninhas tem sido feito principalmente através de métodos culturais, manuais, mecânicos e predominantemente pelo método químico, através da aplicação de herbicidas. Porém, estas medidas utilizadas isoladamente não são suficientes para eliminar toda a interferência das plantas daninhas na cultura, exigindo medidas integradas de controle. Para a execução de um programa integrado de manejo de plantas daninhas, (Christoffoleti, 1988; Christoffoleti \& Passini, 1999) ressaltam que geralmente, são necessárias quatro etapas, ou seja, diagnóstico do problema, escolha dos métodos, implementação e avaliação do programa integrado de controle.

Atualmente na agricultura brasileira o sistema de produção que integra lavoura e pecuária tem sido utilizado de forma intensa no país. Este sistema pode trazer benefícios como a reciclagem de nutrientes, controle de erosão, proteção e melhoria das propriedades físicas, químicas e biológicas do solo, inibição da infestação de pragas, nematóides e outros agentes patogênicos, a supressão da infestação de plantas daninhas e ainda, propiciar alimentação para o gado após a colheita da cultura (Cobucci, 2001; Vilela et al., 2003). A supressão da infestação de plantas daninhas é um aspecto relevante, pois com isso é possível utilizar medidas integradas de manejo de forma mais sustentável e menos dependente de produtos químicos. 
A coexistência entre plantas de diferentes espécies ocupando nichos mais abrangentes no agroecossitema é o princípio básico para o manejo de plantas daninhas na integração lavoura-pecuária, pois com isso o nicho ecológico maior ocupado pelas culturas impede a infestação generalizada de plantas daninhas que ocorre em sistemas de monocultivo. Sendo assim, as plantas daninhas infestantes da área têm menores oportunidades de captura dos recursos do meio e consequentemente infestação e crescimento, reduzindo sua interferência e necessidade de controle. Esta redução deve ser criteriosamente estudada como medida cultural de manejo de plantas daninhas no sentido de racionalizar as práticas agronômicas neste sistema de produção. No entanto, a maioria dos produtores que adotam este sistema de produção necessitam de mais informações sobre os efeitos da integração lavoura-pecuária na infestação das comunidades de plantas daninhas adaptadas ao agroecossistema que consorcia a produção de milho e forrageiras do sistema de integração lavoura-pecuária.

Até o presente momento, no Brasil, existem poucos trabalhos de pesquisa que estudaram a prática da consorciação de gramíneas forrageiras na cultura do milho com o objetivo de avaliar o efeito na supressão e dinâmica da infestação de plantas daninhas e sobre o rendimento do milho e das forrageiras, com vistas à integração lavoura-pecuária. Desta forma, o objetivo desta pesquisa foi de avaliar a influência de três culturas forrageiras (Brachiaria decumbens, Brachiaria brizantha e Panicum maximum) consorciadas à cultura de milho (Zea mays), por meio do sistema de produção de integração lavoura-pecuária sobre: (i) infestação e banco de sementes de três espécies de plantas daninhas (Ipomoea grandifolia, Amaranthus hybridus e Digitaria horizontalis) em convivência; (ii) produção final de matéria verde das culturas forrageiras; (iii) rendimento de grãos da cultura do milho e (iv) curvas de crescimento das plantas de milho, perfilhos das forrageiras e plantas daninhas estudadas. 


\section{REVISÃO DE LITERATURA}

\subsection{Cobertura vegetal do solo: considerações gerais}

A cobertura vegetal do solo, incluindo-se a utilização de adubos verdes e de plantas forrageiras, ou seja, leguminosas e gramíneas, é uma prática conhecida desde a antiguidade, podendo ser definida como a incorporação ao solo de material vegetal não decomposto, produzido ou não no local. Desta operação, resultam alterações desejáveis no solo, em seus atributos químicos, físicos e biológicos, propiciando à cultura subseqüente diversos benefícios por meio destas mudanças, refletindo normalmente em maiores rendimentos das culturas econômicas (Primavesi, 1986; Mascarenhas et al., 1986; Cáceres \& Alcarde, 1995; Severino, 2000; Ambrosano, 2001).

Em áreas com sistema de produção conservacionista, em que se adota o sistema de plantio direto, deixando uma fitomassa na superfície do solo, a infestação de plantas daninhas é afetada por fatores físicos, químicos e biológicos. Dentre os fatores físicos destacam-se a dificuldade da emergência das plantas daninhas, que apresentam pequenas quantidades de reservas em suas sementes para atravessar a camada de fitomassa, e as sementes dormentes que necessitam de luz para quebra de dormência e subseqüente germinação (sementes fotoblásticas positivas). A liberação de inibidores bioquímicos que afetam a germinação e/ou crescimento e desenvolvimento das plantas, produzidos diretamente pelos restos vegetais, ou pelos microorganismos que se desenvolvem durante seu processo de decomposição pode também inibir a germinação e emergência de algumas espécies. A condição de microambiente, ocasionada por esta fitomassa, na superfície do solo, aumenta a biocenose praticada pelos microrganismos habitantes do 
solo, nos primeiros centímetros do perfil, de tal forma que diversas sementes e seedlings de plantas daninhas podem ser deterioradas ou predadas (Severino, 2000).

Muitas vezes, principalmente nas condições de clima tropical, o manejo inadequado do solo pode trazer, por meio dos cultivos, conseqüências drásticas, exaurindo-o de suas reservas orgânicas e minerais, transformando-o em solo de baixa fertilidade, tornando-se necessário o emprego constante de práticas agrícolas, que visam amenizar essas conseqüências (Mello \& Brasil Sobrinho, 1960; Primavesi, 1986).

Com a prática da utilização de plantas como cobertura vegetal do solo, é possível recuperar a fertilidade dos solos, proporcionando aumento do teor de matéria orgânica, da capacidade de troca de cátions e da disponibilidade de macro e micro nutrientes; formação e estabilização de agregados; melhoria da infiltração de água e aeração; diminuição diuturna da amplitude da variação térmica; controle de nematóides e, no caso das leguminosas, incorporação ao solo de nitrogênio, obtido através da fixação biológica (Igue, 1984; Calegari et al., 1993; Cáceres \& Alcarde, 1995; Oliveira, 1996).

Esta é uma das práticas agrícolas, que nos agroecossistemas recicla, de forma semelhante, a uma floresta, maior quantidade de energia. É importante ressaltar que, em solos degradados, estas plantas cumprem o papel que um aporte de matéria orgânica não cumpriria integralmente (Piamonte, 1996). Ainda, segundo esse autor, as adubações, incluindo-se aqui a adubação verde, devem ser entendidas como a prática de vitalização do solo, ou seja, conferir a ele elementos que permitam o estímulo crescente de seu complexo biótipo.

O emprego de plantas como cobertura vegetal do solo diz respeito a um cultivo de plantas com o objetivo de adubação, a intensificação da biota do solo, resultando no seu melhoramento para uso agrícola. Com isto, a meta deste tipo de procedimento é claramente traçada: assegurar e melhorar a fertilidade do solo nos agroecossistemas (Vogtmann \& Wagner, 1987). Assim, segundo esses autores, esta prática fornece: abastecimento do solo com material orgânico, enriquecimento do solo com nutrientes (macro e micro elementos), melhora da estrutura do solo, intensificação da atividade 
biológica do solo, diminuição da lixiviação de nutrientes e, diminuição da incidência de pragas, patógenos e plantas daninhas nas culturas.

França \& Moreira (1988), citaram que um dos sistemas de produção bastante propagado na agricultura é a o emprego de plantas como cobertura vegetal viva, geralmente usando-se leguminosas. As leguminosas seriam cultivadas e, atingindo o ponto de florescimento, cortadas e incorporadas mecanicamente ao solo, ou seriam mantidas como cobertura viva no solo até pouco antes da maturação das sementes, quando seriam incorporadas ou preferencialmente cortadas e mantidas como cobertura morta. Segundo os autores, a matéria orgânica conseguida neste período é mais lignificada e, portanto, resiste mais a decomposição e também, quando possível, as sementes podem ser colhidas e usadas para novos cultivos, ou vendidas, acrescentando uma renda extra à unidade produtiva. Por outro lado, nas últimas décadas houve uma diminuição na utilização desta prática agrícola, devido à intensificação dos cultivos e aumento da disponibilidade de fertilizantes químicos (Singh et al., 1991).

Atualmente, observa-se que os produtores rurais estão em busca de um sistema de produção agrícola que seja capaz de recuperar a fertilidade do solo, incluindo a utilização de gramíneas e ou leguminosas como cobertura no outono-inverno, que tem apresentado resultados satisfatórios, na obtenção de renda extra, além dos efeitos benéficos agregados na cultura subseqüente (Bulisani et al., 1987).

De acordo com Franco \& Souto (1984), as leguminosas geralmente usadas em adubação verde, fixam em média, $188 \mathrm{~kg}$ de N.ha ${ }^{-1}$.ano ${ }^{-1}$, sendo este adicionado ao solo, podendo assim racionalizar a aplicação de nitrogênio. Kohl et al. (1971), mencionaram que com esta prática pode-se recuperar a fertilidade do solo perdida devido ao manejo inadequado e a adoção de monocultivo, obter $\mathrm{N}$ para a cultura seguinte e evitar, desta forma, adubos altamente solúveis que podem causar impacto ambiental desfavorável. Resultados positivos quanto ao fornecimento de $\mathrm{N}$ para as culturas de milho, cultivado após soja, foram observados por Mascarenhas et al. (1986). Por outro lado, Alcântara \& Bufarah (1999), verificaram que as gramíneas, de forma geral, podem incorporar até 180 
kg de N.ha ${ }^{-1}$.ano ${ }^{-1}$. No Brasil, a prática da adubação verde vem sendo utilizada há mais de trinta anos com excelentes resultados sob as mais diversas condições de produção (Miyasaka, 1984). Porém, embora sejam encontrados dados de pesquisa obtidos nas mais diversas instituições do país, indicando o efeito favorável na produção agrícola, esta prática ainda continua restrita a um número reduzido de agricultores (Freitas et al., 1984).

Na utilização de plantas como cobertura verde, emprega-se tanto gramíneas como leguminosas. Entretanto, a razão da preferência pelas leguminosas é principalmente pelo fato destas, em simbiose com bactérias do gênero Rhizobium e Bradyrhizobium, fixarem $\mathrm{N}$ do ar em quantidade suficiente para satisfazer suas necessidades e gerar excedentes para a cultura que a sucede. Sua composição química e relação Carbono/Nitrogênio (C/N) são outras importantes características. Por outro lado, somente este procedimento não supre o solo em relação as suas deficiências minerais totais, havendo necessidade, em solos deficientes de P, K, Ca, Mg, de se aplicar os referidos elementos (Azcón et al., 1991; Ambrosano et al., 1999; Ambrosano, 2001).

Ainda, segundo estes autores, o sistema radicular das leguminosas pode alcançar elevadas profundidades com capacidade de absorver água e extrair elementos minerais destas camadas do solo, proporcionando assim, uma reciclagem e redistribuição de nutrientes. Contudo, o efeito das raízes na adubação verde é pouco estudado devido às dificuldades em se obter os dados.

A recomendação da cobertura vegetal nos agroecossistemas está relacionada ao sistema de produção vigente em uma situação agrícola específica, devendo-se considerar, entretanto, a não interferência com as atividades agropecuárias principais da propriedade; o custo dessa prática; a disponibilidade de sementes e, também, a preferência do agricultor (Wutke, 1993 e 1998). Nestas pesquisas a autora ressalta, ainda, a importância de se considerar as características próprias de cada espécie tais como adaptação edafoclimática (termo e fotoperíodo, disponibilidade hídrica, radiação solar), ciclo (anual, bianual, ou perene), porte da planta (rasteira ou ereta, podendo o 
cultivo ser arbustivo ou arbórea), época de semeadura (verão ou inverno), produto final principal (grãos, fitomassa ou ambos), e, ainda, práticas culturais e fertilidade do solo que afetam sobremaneira a quantidade de fitomassa produzida e, conseqüentemente, o seu efeito. Este pode ainda ser obtido não só pela cobertura vegetal do solo, como também pela própria produção de grãos.

A utilização agrícola economicamente viável de solos arenosos e pobres em nutrientes, com baixo teor de matéria orgânica, em diversas regiões do mundo, apenas se tornou possível devido à introdução da prática da adubação verde (Derpsch et al., 1991).

Sendo assim, um sistema onde a prática do emprego de plantas como cobertura vegetal do solo traz, além dos benefícios citados, incremento na produtividade, economia de adubo nitrogenado na cultura que a sucede no esquema de rotação ou de sucessão e pode fazer parte, como uma valiosa ferramenta, de um sistema de manejo integrado de plantas daninhas (Severino, 2000). Por outro lado, estas plantas, assim como as outras, têm limitações quanto ao clima, solo e disponibilidade de água e que para a implantação deste sistema de produção, independentemente da sua finalidade, não existem regras pré-estabelecidas e a experimentação local é de fundamental importância (Wutke, 1998; Severino, 2000).

\subsection{Cobertura vegetal do solo na cultura do milho}

O cultivo de milho consorciado com leguminosas resulta em considerável economia de fertilizante nitrogenado para a cultura do milho, embora a expressão deste efeito seja variável entre os experimentos conduzidos. Esta condição reforça a recomendação de Muzilli et al. (1989), que citam que para fazer parte de um determinado sistema de produção, uma espécie de planta destinada ao consórcio, necessita ser criteriosamente avaliada de forma regional, tanto em relação ao seu crescimento e desenvolvimento quanto em seus diferentes potenciais de aproveitamento.

Medeiros et al., (1990), estudaram que o efeito residual da rotação de culturas com aveia ou tremoço, semeados individualmente ou consorciados, sobre o rendimento das culturas de milho e algodão. Verificaram que os tratamentos com tremoço solteiro 
em densidades normais de semeadura ou em alta densidade proporcionaram rendimentos para a cultura do milho e algodão, semeados a seguir, superiores aos da rotação com aveia, provavelmente em função do nitrogênio adicionado pela leguminosa ao sistema.

Mitchell \& Teel (1977), pesquisaram o consórcio entre Avena sativa L. (aveia) e Vicia vilosa Roth (ervilhaca peluda) e notaram que a produção de fitomassa seca da

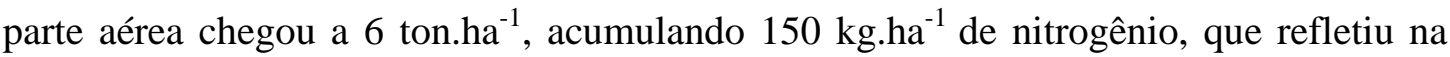
produção de grãos de milho semeado a seguir na ordem de 6 ton.ha ${ }^{-1}$.

Também Sarrantonio \& Scott (1988), estudaram os sistemas de cultivo apropriados para Vicia pilosa Roth e observaram que esta leguminosa teve efeito favorável na produção de milho, tanto em sistema convencional ou de semeadura direta. Entretanto, em condições de déficit hídrico, o sistema de semeadura direta do milho apresentou rendimento superior. Por outro lado, estudando coberturas verde de inverno, Derpsch et al. (1985), verificaram que a aveia-preta produziu maiores quantidades de matéria seca, sendo que a cultura do milho em sucessão a este adubo verde apresentou um rendimento de grãos muito baixo, se igualando aos tratamentos com centeio e girassol. Estas espécies apresentaram a mais elevada relação $\mathrm{C} / \mathrm{N}$ das espécies pesquisadas.

A proteção da superfície do solo com resíduos vegetais é um dos meios mais efetivos para reduzir as perdas de solo por erosão em função, principalmente, por impedir o impacto direto das gotas de chuva sobre o solo, redução no selamento dos poros, na velocidade de escorrimento da enxurrada e aumento na infiltração de água (Mannering \& Meyer, 1963; Primavesi, 1986).

A ervilhaca comum, devido à sua significativa produção de fitomassa verde, protege a superfície do solo contra o impacto direto das gotas da chuva e possibilita a

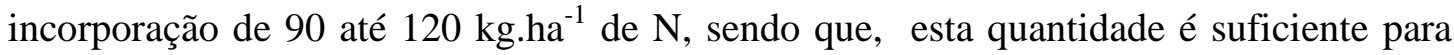
suprir parcialmente a demanda desse nutriente para a cultura subseqüente do milho (Power et al., 1983). 
Pesquisa de Reicoski (1994), confirma que a importância da interação do complexo solo, clima e colheita no resultado de produção de grãos, resíduos e controle da erosão requer um nível de tecnologia elevada. Com a cobertura vegetal, aumenta a infiltração de água no solo e minimiza-se a evaporação, tornando-a disponível para as plantas, além de reduzir o escorrimento superficial.

Triplett (1986) menciona que o resíduo do centeio e trigo para cobertura é bastante eficiente em função de sua alta concentração de celulose e lignina e alta relação $\mathrm{C} / \mathrm{N}$, que resulta em maior resistência à decomposição. Por outro lado, as leguminosas anuais de inverno apresentam boa cobertura e suprem parte do nitrogênio que as culturas de verão, como o milho e sorgo, necessitam (Ebelhar et al., 1984; Frye et al., 1988).

Também Muzilli (1983), verificou que a maior demanda de $\mathrm{N}$ está ligada à relação $\mathrm{C} / \mathrm{N}$ e a atividade biológica em que a mineralização é mais lenta devido ao menor contato entre o material orgânico e a população microbiana do solo. Bruce et al. (1991), salientam o efeito positivo deste procedimento, mencionando que a cobertura verde mantém ou aumenta o potencial produtivo dos solos, pois é uma fonte de biomassa que contribui para aumentar a matéria orgânica do solo.

Por ocasião da semeadura do milho, o solo deverá apresentar-se com temperatura superior a $10^{\circ} \mathrm{C}$, aliado a umidade próxima à capacidade de campo, para possibilitar o desenvolvimento dos processos de germinação e emergência (Fancelli \& Dourado Neto, 1996). Desta maneira, a densidade e a distribuição da cobertura vegetal é o princípio fundamental para a preservação do solo contra os efeitos climáticos. Quanto menor forem os efeitos, tanto mais densa será a vegetação que o recobre e protege. Nas regiões tropicais, o solo descoberto, submetido à ação direta do sol e da água da chuva, fica exposto a inúmeros prejuízos. Assim, com uma boa produção de fitomassa, consegue-se o estabelecimento da proteção sobre o solo, amenizando o efeito prejudicial dos fatores meteorológicos (Primavesi, 1986). 


\subsection{Controle de plantas daninhas pela cobertura vegetal do solo na cultura do milho}

A cobertura vegetal viva de culturas consorciadas que permanece no solo durante toda a estação de crescimento da cultura principal pode ocasionar a competição direta por recursos essenciais de crescimento, fato que, possivelmente, será a principal forma de supressão das plantas daninhas pela cobertura vegetal (Severino, 2000). De maneira geral, as plantas daninhas interferem no desenvolvimento das plantas de milho com variável intensidade em função da época de ocorrência, da população e das espécies presentes no local (Zagonel et al., 2000).

Nos dias atuais, as inovações tecnológicas para o controle de plantas daninhas na cultura do milho contemplam: o conhecimento da dinâmica do banco de sementes que sustenta o recrutamento da população de plantas daninhas; a aplicação de herbicidas em condições de pós-emergência; a utilização de herbicidas juntamente com outros pesticidas; a integração da cultura do milho com a produção de forrageiras destinadas à pecuária e a necessidade do produtor estar devidamente informado sobre todas as possibilidades e alternativas das medidas de controle das plantas daninhas. (Christoffoleti \& Mendonça, 2001).

Assim sendo, a cobertura vegetal do solo pode potencialmente inibir a germinação e o estabelecimento de plantas daninhas com muito mais eficiência do que resíduos dessecados de culturas. Teasdale (1998), verificou que a clorofila, em uma vegetação viva intercepta a luz vermelha $(660 \mathrm{~nm})$ e em menor quantidade a luz vermelha distante $(710 \mathrm{~nm})$, de tal forma que a luz difusa que atinge a semente da planta daninha, localizada abaixo da folhagem da cobertura vegetal viva do solo, é induzida a dormência, pois o fitocromo é convertido para a forma inativa. A transmitância da luz e a amplitude térmica foram também reduzidas em maior intensidades pelas plantas empregadas como cobertura vegetal, quando comparado com palhada dessecada. Não obstante, as plântulas que eventualmente emergem, debaixo da folhagem da cobertura 
vegetal do solo, estão em desvantagem competitiva quando em competição o adubo verde ou a cultura principal.

As pesquisas realizadas com leguminosas usadas como cobertura vegetal viva, têm mostrado uma redução nas populações de plantas daninhas em alguns sistemas de produção. Hartwig (1989) mostrou que Coronilla varia L., usada como cobertura viva de solo, na cultura do milho, reduziu a população da planta daninha dente-de-leão (Taraxacum officinale) em 74\% quando comparada com áreas onde a palhada foi deixada na superfície para a realização da semeadura direta.

Enache \& Ilnicki (1990), verificaram melhor controle das plantas daninhas na cultura do milho, foi obtido quando foi usada a cobertura viva de plantas de Trifolium subterraneum L., a qual produz sementes subterrâneas. Esta conclusão foi tirada comparando o tratamento de cobertura viva com outros tratamentos com e sem o uso de herbicidas.

White \& Scott (1991), mostraram que várias leguminosas perenes, depois de estabelecidas em culturas de cereais, reduziram a biomassa de plantas daninhas na área, quando comparada com a testemunha, sem a presença de cobertura. DeHaan et al. (1994), verificaram que em Brassica hirta, cultivada como cobertura vegetal viva do solo na cultura do milho, durante seis a oito semanas, reduziu, em média, $82 \%$ da biomassa das plantas daninhas infestantes na área, quando comparado com outros tratamentos.

Embora estas espécies possam ter um potencial para a supressão do desenvolvimento de certas espécies de plantas daninhas, a experiência sugere que o controle total das plantas infestantes, na natureza, dificilmente ocorre pela supressão causada por uma única espécie, mas sim existe sempre a necessidade de uma combinação de espécies de plantas para suprimir totalmente a planta daninha. Por outro lado, mesmo a melhor das espécies perenes desenvolve falhas no seu crescimento ou na ocupação de todos os nichos ecológicos, de tal maneira que alguma diversidade de espécies sempre ocorre, sendo que espécies de plantas daninhas com uma fenologia e 
morfologia compatíveis com a espécie utilizada como cobertura vegetal podem tornar-se infestante da área (Severino, 2000).

Wilkinson et al. (1987), relataram que a infestação de plantas daninhas constituiu na principal limitação no estabelecimento de Festuca arundinacea, usada como adubo verde na cultura do milho após três anos de estabelecimento. Por outro lado, Mohler (1991), verificou o estabelecimento de uma população de plantas daninhas em Trifolium repens L., usado como adubo verde perene na cultura de milho doce, de tal maneira que reduziu a produção da cultura de milho, depois de quatro anos do estabelecimento deste adubo verde perene.

Desta maneira, embora estas plantas, possam ser ferramentas efetivas para o controle de plantas daninhas, eles requerem um manejo compatível destas, particularmente para prevenir a infestação e estabelecimento de espécies de plantas daninhas com o tempo (Severino, 2000).

\subsection{Controle do crescimento das plantas utilizadas como cobertura vegetal do solo}

Essas espécies de plantas, que tem a capacidade de suprimir de forma significativa o crescimento e desenvolvimento das plantas daninhas, pode também afetar a produção da cultura principal. A comparação entre várias gramíneas e leguminosas, usadas como cobertura vegetal viva, mostrou que as culturas que foram mais supressivas para as plantas daninhas, foram também supressivas para a produção da cultura de milho (Echtenkamp \& Moomaw, 1989).

Em um outro trabalho de pesquisa foi verificado que práticas de manejo que permitiram Brassica hirta suprimir o desenvolvimento de plantas daninhas teve como conseqüência, também a redução do desenvolvimento da cultura de milho (De Haan et al., 1994). A intensidade da redução da infestação das plantas daninhas e da cultura principal está diretamente relacionada com a quantidade de biomassa produzida pela cobertura vegetal utilizada.

Elkins et al. (1983) e Nicholson \& Wien (1983), mostraram que existe uma alta correlação entre a biomassa de plantas empregadas em cobertura vegetal do solo e 
redução da produção da cultura principal. Desta maneira, o manejo do crescimento dessas espécies é, portanto, essencial para o desenvolvimento e estabelecimento destes em sistemas de produção.

\subsection{Dinâmica do Banco de Sementes de plantas daninhas na cultura do milho}

O banco de sementes de um solo pode ser entendido como sendo a reserva de sementes e propágulos vegetativos em profundidade e na superfície do solo (Roberts, 1981). Segundo Fernández-Quintanilla et al. (1991), esta reserva constitui-se a origem do ciclo da vida das espécies vegetais. Por outro lado, ela é também, um arquivo de informações das condições ambientais e práticas culturais passadas, sendo um fator importante de avaliação do potencial de infestação da comunidade infestante no presente e futuro (Templeton \& Levin, 1979).

O banco de sementes do solo é utilizado para estudar as relações quantitativas entre a sua população e a da flora infestante (Dessaint et al., 1990). Essas informações permitem elaborar índices de predição e modelos de emergência, permitindo a previsão de futuras infestações e definição de medidas adequadas de manejo (Barralis \& Chadoeuf, 1987; Fernández-Quintanilla, 1988).

A composição e densidade do banco de sementes expressam grandes variações, tendo relação direta com o histórico da área e com o sistema de produção adotado. O sistema de preparo de solo afeta diretamente a produção de sementes de planta daninha na área, bem como o distúrbio causado no solo determina a distribuição vertical quantitativa do banco de sementes. Desta forma, a densidade da população de plantas daninhas na área é afetada diretamente pelas práticas culturais adotadas (Buhler, 1995).

Estudos da influência do tipo de preparo de solo sobre o banco de sementes indicam que mais de $70 \%$ das sementes se encontram na camada de $0-5 \mathrm{~cm}$, para parcelas sem preparo, e 33\% para locais onde foi feita escarificação superficial do solo (Clements et al., 1996; Cardina \& Sparrow, 1996).

O revolvimento do solo estimula a germinação das sementes por expô-las a luz e por possibilitar uma maior temperatura e umidade. Entretanto, o efeito das práticas de 
preparo de solo sobre a quebra de dormência das sementes é função também da distribuição vertical das sementes no perfil, antes e depois do cultivo (Cavers \& Benoit, 1989).

A dormência de sementes é o fenômeno pelo qual sementes de uma determinada espécie, mesmo sendo viáveis e tendo todas as condições ambientais favoráveis, deixam de germinar (Carvalho \& Nakagawa, 1983). Sementes não dormentes germinam com facilidade em condições ideais de umidade, temperatura e oxigênio. Quando não há germinação ou quando esta ocorre com dificuldade, mesmo favorecida por fatores ambientais, elas são ditas dormentes (Côme, 1982). A dormência é a principal causa da sobrevivência das sementes de plantas daninhas no solo, causando infestações prolongadas nas aéreas de cultivo, distribuindo a germinação ao longo do tempo (Chadoeuf-Hannel, 1985).

A dinâmica de um banco de sementes é influenciada diretamente pela sucessão de eventos de entrada e saída de sementes do banco em relação ao tempo (Simpson et al., 1989) e determina em que densidade será encontrada uma espécie na comunidade, tanto como reservas de sementes, quanto como plantas, mesmo que a correlação entre essas duas seja baixa (Rice, 1989).

A cobertura vegetal do solo pode ser considerada uma prática eficiente no controle de plantas daninhas por diversificar a pressão de seleção, alterando os padrões de distúrbios. Buhler et al., (1997), citam que a rotação de culturas, incluindo o emprego de espécies como cobertura vegetal do solo, reduz o tamanho do banco, pois a seqüência de cultivos, propicia diferentes modelos de competição, alelopatia, distúrbios do solo em cada uma das culturas seqüenciadas, reduzindo assim a pressão de seleção para plantas daninhas específicas. Em sistemas de rotação, quando comparado com monocultivo, foi encontrada menor quantidade de sementes no solo (Ball \& Miller, 1990; Schreiber, 1992; Val, 1996; Voll \& Gazziero, 1997).

Skora Neto (2001) pesquisou as alterações populacionais das plantas daninhas em função das medidas de controle adotadas em longo prazo na cultura do milho, 
observando que as estratégias utilizadas na cultura são determinantes na composição quantitativa e qualitativa da comunidade infestante. Ainda esta pesquisa, evidenciou que o controle de plantas daninhas durante todo o ciclo da cultura evitando desta forma a produção de sementes por um período de dez anos, reduziu expressivamente a densidade da planta daninha Brachiaria plantaginea (capim-marmelada).

Sendo assim, o tamanho, composição do banco de sementes e a vegetação presente na superfície do solo, são indicadores de todo o sistema de manejo do solo e plantas daninhas que foi empregado nos últimos anos (Caetano, 2000).

Nos agroecossistemas, a redução do tamanho do banco de sementes, através de estratégias de manejo, tem sido objeto de pesquisas, que possam contribuir nos sistemas de manejo integrado de plantas daninhas, sendo que utilização de plantas como cobertura vegetal é, sem dúvida, uma destas estratégias.

\subsection{Fenologia da cultura de milho}

De acordo com Fancelli (1986), o conceito de fenologia envolve o conhecimento de todas as etapas de crescimento e desenvolvimento da vida vegetal, uma vez que a reunião destes conhecimentos, de maneira ordenada e concisa, possibilita a determinação das relações e do grau de influência dos fatores envolvidos no processo produtivo, favorecendo o estabelecimento de estratégias de manejo e de tomada de decisão.

O ciclo da cultura do milho, segundo Fancelli (1994), compreende diferentes etapas de desenvolvimento, tais como: i) emergência (cerca de 7 a 10 dias): período da semeadura até o aparecimento da plântula; ii) crescimento vegetativo (com extensão variável, dependendo da precocidade do material): da emissão da segunda folha até o início do florescimento; iii) florescimento (cerca de 8 a 10 dias): período desde o início da polinização até o início da frutificação; iv) frutificação (cerca de 50 a 60 dias): etapa compreendida entre o início do enchimento dos grãos até o início da maturação; v) maturação (cerca de 25 a 30 dias): etapa desde o final da maturação até o ponto de maturidade fisiológica. 
A divisão considerada das etapas de desenvolvimento em estádios facilita o manejo (referência exata) e o estudo da cultura, bem como objetiva a possibilidade do estabelecimento de correlações entre elementos fisiológicos, bioquímicos, climatológicos, fitogenéticos, entomológicos, fitopatológicos e fitotécnicos com o desempenho da planta e ao atributo de interesse (Fancelli, 1986). O mesmo autor destaca, ainda, que o manejo fundamentado em simples escala de tempo pode ocasionar equívocos, dependendo das condições que a cultura for submetida.

O conhecimento da fenologia da cultura do milho pode ser útil no estabelecimento das estratégias de manejo das plantas daninhas na cultura. Existe uma correlação direta entre o estádio fenológico das culturas e o período de convivência com as plantas daninhas, destacando-se que a interferência negativa ocasionada pela presença das plantas daninhas é função do estádio fenológico das culturas e do crescimento simultâneo da planta daninha durante os estádios fenológicos da cultura do milho. Assim, é evidente que as culturas consorciadas com o milho suprimem o crescimento e desenvolvimento das plantas daninhas e da mesma forma podem interferir na cultura, portanto medidas estratégicas devem ser adotadas para minimizar esta interferência.

\subsection{Integração lavoura-pecuária}

A integração entre lavouras anuais e pastagens tem surgido como uma alternativa para a recuperação dos solos degradados pela atividade agropecuária. Bons resultados na produtividade da soja e no ganho de peso dos animais têm sido alcançados em sistema integrados propostos pelo Instituto de Pesquisa do estado do Paraná (IAPAR). Neste sistema, manejam-se duas áreas, uma destinada a piquetes e outra a cultivos anuais, como soja, milho, etc. O gado permanece em piquetes e no inverno é transferido para as áreas de cultivos anuais (Colozzi Filho et al., 2000).

Os efeitos das práticas agrícolas sobre a comunidade infestante e microbiana do solo são variados e podem atuar diretamente sobre grupos microbianos específicos, seus processos e sua diversidade. Como a sustentabilidade da agricultura nos trópicos depende da reciclagem de nutrientes, da matéria orgânica, sendo que a comunidade 
microbiana tem papel fundamental neste processo, pode-se concluir que a criação de condições favoráveis para a comunidade microbiana e sua atividade biológica devem ser consideradas em programas de manejo da fertilidade dos solos (Colozzi Filho et al., 2001).

Também, a integração entre a produção animal e vegetal constitui-se num dos pilares da Agricultura Biodinâmica, preconizada por Rudolf Steiner, a qual deixa claramente explícito que "cada propriedade é como um organismo que deve buscar sua individualidade, reduzindo, assim, a sua dependência de insumos externos” (Carvalho, 1999).

Na integração lavoura-pecuária, torna-se mais fácil a produção de forragem na época mais crítica do ano, isto é, no período de seca tanto sob pastejo quanto como suplemento de feno e silagem (Broch et al., 1997). Ainda, de acordo com os autores, a integração lavoura-pecuária, além de viabilizar o desenvolvimento de duas atividades, promove a rotação de culturas, a qual além de contribuir para a produtividade do solo, é essencial na viabilização da semeadura direta.

A rotação de culturas consiste em alternar espécies vegetais no decorrer do tempo, em uma mesma área. A rotação de culturas quando bem conduzida preserva ou melhora as características físicas, químicas e biológicas do solo; contribui no controle e redução da infestação de plantas daninhas, patógenos, pragas e erosão; aumenta o teor de matéria orgânica do solo, protegendo-o dos fatores climáticos adversos; contribui na viabilização da semeadura direta e na diversificação da produção agropecuária (Broch et al., 1997). Os autores citam também que para se obter aumento de produtividade, tanto nas lavouras como na pecuária, o caminho mais curto e seguro é por meio da integração lavoura-pecuária.

Assim, existe a necessidade urgente da realização de pesquisas gerando tecnologias para aprimorar os sistemas produtivos baseados na integração lavourapecuária e ao mesmo tempo fornecer suporte tecnológico para sua expansão. 


\subsection{Medidas de interferência de plantas forrageiras consorciadas com a cultura do milho}

Interferência é o efeito combinado de pressões ambientais diretas e indiretas que ocorrem em plantas, isto é, o conjunto de ações que incide numa determinada cultura em decorrência da presença de uma outra comunidade vegetal presente num determinado local (Pitelli, 1985).

São conhecidas interações positivas e negativas, sendo a competição pelos recursos do ambiente a mais importante interação negativa identificada em um sistema biológico (Wilson, 1988; Radosevich, 1996). O conhecimento da forma como a forrageira e a cultura são afetadas em um consórcio é de fundamental importância para haja êxito na formação e/ou na recuperação de pastagens e produção satisfatória da cultura. Dentre os fatores relacionados às ações de interferência podem ser citados a competição por água, luz, nutrientes e os efeitos alelopáticos.

\subsubsection{Competição}

Entende-se por competição a distribuição dos recursos limitantes do crescimento como água, dióxido de carbono, nutrientes e luz, entre as espécies no agroecossistema e a eficiência de cada uma delas em utilizar esses recursos para a produção de biomassa sendo que além desses recursos, pode-se citar ainda o espaço (Victoria Filho, 2000; Rohrig \& Stulzel, 2001). Desta forma, a disposição das plantas no consórcio, época e forma de estabelecimento da forrageira e níveis de adubação, influem acentuadamente na competição entre plantas (Souza Neto, 1993). Neste contexto, a resposta das plantas à disponibilidade de recursos segue uma curva padrão, sendo a resposta pequena se o recurso é limitado e máxima quando o ponto de saturação é atingido, podendo até declinar quando em excesso (Radosevich, 1996). A competição por água, nutrientes e luz é difícil de ser separada, uma vez que esses recursos estão interligados, pois a deficiência de um deles afeta a capacidade competitiva das espécies cultivadas pelos demais (Fleck, 1992). 
As condições edáficas, como pH, densidade do solo e outros fatores, influenciam diretamente na utilização dos recursos pelas plantas, podendo limitar a resposta da planta tanto pela carência quanto pela abundância, até que seja atingido um nível ideal. No entanto, a competição apenas é constatada quando os competidores utilizam recursos de sobrevivência em intensidade superior à capacidade do meio em fornecer estes recursos. Esta situação pode ser evidenciada em condições de sombreamento, onde um dos competidores impede o acesso do outro (Pitelli, 1985).

Os fatores que determinam a maior competitividade entre as espécies são: o porte e a arquitetura da planta; a maior velocidade do crescimento e maior extensão do sistema radicular; a menor suscetibilidade da espécie às intempéries climáticas (como geadas e veranicos); o maior índice de área foliar e, a maior capacidade de produção e liberação de substâncias químicas com propriedades alelopáticas (Silva et al., 2004).

Uma planta é considerada competidora eficaz quando utiliza rapidamente um determinado recurso ou quando é capaz de continuar seu desenvolvimento mesmo com níveis escassos desses recursos no ambiente (Radosevich, 1996). O milho é considerado um exímio competidor quando combinado com plantas de menor porte, como é o caso das plantas forrageiras do gênero Brachiaria.

De acordo com Silva (1997), as espécies do gênero Brachiaria apresentam rápido crescimento inicial do sistema radicular e também da parte aérea, em condições de verão. Conseqüentemente, essas espécies apresentam acentuada competição por água, luz e nutrientes com as culturas, principalmente quando presentes no início do seu desenvolvimento.

A forrageira quando estabelecida em consórcio mantém seu crescimento sob o sombreamento ocasionado pelo milho. Esse comportamento também foi notado por Dias Filho (2000), que verificou em espécies de braquiária, particularmente, Brachiaria brizantha sob sombreamento artificial, plasticidade fenotípica quanto à captura de radiação em resposta ao sombreamento, e como conseqüência, a capacidade de manter o crescimento mesmo com restrição de luz. 
Segundo Fleck et al. (2004), os efeitos negativos da competição sobre o rendimento das culturas geralmente decrescem com o aumento do intervalo de tempo entre a emergência da cultura e das espécies concorrentes.

A B. brizanta empregada em monocultivo, apresentou, a partir dos 45 dias após a emergência (DAE), um aumento na taxa de acúmulo de biomassa seca, sendo que a taxa de acúmulo de massa seca do milho nestas mesmas condições foi superior à da forrageira, especialmente quando este se beneficiou da adubação nitrogenada aplicada em cobertura (Cobucci, 2003).

Outras pesquisas realizadas em argissolos argilosos na Universidade Federal de Viçosa, MG - demonstraram a ocorrência de um certo atraso no estabelecimento da forrageira, beneficiando a produção de grãos de milho em razão da taxa de crescimento da forrageira coincidir com o final do período crítico de competição com a cultura. Entretanto, este comportamento além de estar relacionado ao ambiente edáfico, representado pela textura e drenagem, também pode ser influenciado pelas condições climáticas (precipitação, insolação e temperatura) e pelas características das espécies utilizadas (Silva et al., 2004).

O princípio da competição se baseia no fato de que as primeiras plantas que surgem no solo se estabelecem efetivamente e dificultam o desenvolvimento das demais. Portanto, é imprescindível fornecer as condições necessárias adequadas para a cultura se estabelecer antes do surgimento da vegetação espontânea ou no caso da integração lavoura-pecuária é importante que a cultura de grãos se estabeleça mais rapidamente que a cultura forrageira.

\subsubsection{Competição por água}

A competição por água é o fator mais limitante da distribuição e produtividade de espécies vegetais pelo mundo (McWilliam, 1986). As plantas desenvolveram várias respostas ou mecanismos fisiológicos e morfológicos para suportar períodos de estresse hídrico, desenvolvendo adaptações tanto na parte aérea quanto no sistema radicular (Jefferies, 1993). 
As espécies tolerantes a seca, como a Brachiaria brizantha, apresentam uma tolerância plasmática em baixo potencial de água e, freqüentemente, em baixo potencial osmótico. Desta forma, segundo estudos realizados por Silva (1997), maiores teores de água no solo propiciam maior índice de consumo de água que, por sua vez, está diretamente relacionado com o maior acúmulo de biomassa seca pela $B$. brizantha.

O efeito do estresse hídrico em milho é função do estádio de desenvolvimento da cultura, da duração e severidade do estresse e da eficiência no uso da água pelas plantas (Lorens et al., 1987). De maneira geral, a competição por água induz a planta a competir ao mesmo tempo por luz e nutrientes, notadamente nitrogênio e potássio.

Entende-se por uso eficiente da água (UEA) a relação existente entre a biomassa seca produzida e a unidade de massa de água absorvida. O milho, por apresentar rota fotossintética $\mathrm{C}_{4}$, tem melhor UEA que as espécies com rota fotossintética $\mathrm{C}_{3}$, porém não apresenta vantagem sobre aquelas que possuem rota fotossintética semelhante, como o capim-braquiária e o capim-colonião. Segundo Morris \& Garrity (1993), em cultivos consorciados, há um melhor UEA comparado aos cultivos solteiros, desde que as espécies consorciadas não estejam sob severa deficiência hídrica. A espécie dominante dentro de um consórcio eleva seu UEA por meio da absorção de parte da água disponível no período de convivência, reduzindo a água disponível às plantas dominadas (Chastain \& Grabe, 1989).

Macedo \& Zimmer (1990), visando a implantação de pastagens com semeadura simultânea de milho e B. brizantha, realizada em janeiro e outubro de 1989, no estado de Mato Grosso do Sul, constataram interferência significativa no rendimento de grãos de milho quando a semeadura de ambas as espécies foi realizada em janeiro, época desfavorável ao desenvolvimento desse cereal. No entanto, na semeadura realizada em outubro, a produção de grãos foi mais elevada e menos afetada pela forrageira, devido às condições favoráveis de precipitação e temperatura. 


\subsubsection{Competição por luz}

A radiação luminosa é um recurso vital para a fotossíntese e o crescimento das plantas, exercendo um papel importante na habilidade competitiva entre espécies. A competição pela luz é complexa e sua magnitude é influenciada pela espécie e rota fotossintética das espécies envolvidas.

No sistema de produção consorciado, o balanço de energia proporcionado pela luminosidade no interior do dossel torna-se mais complexo quando comparado ao dossel homogêneo de monoculturas, devido às diferenças entre espécies, como altura, arquitetura do dossel, taxa fotossintética e partição de fotoassimilados (Keating \& Carberry, 1993). Assim, quando as plantas consorciadas apresentam diferentes estruturas de crescimento ou diferentes distribuições da área foliar, ocorre um maior aproveitamento da luz. Para Willey (1979), uma outra forma de se aumentar a eficiência no aproveitamento da luz, poderia ser obtida com a utilização de diferentes níveis de exigências.

Segundo Rajcan \& Swanton (2001), a quantidade e a qualidade são os componentes da radiação que afetam o resultado da competição entre plantas. A intensidade da radiação interceptada pela planta - componente quantitativo - determina a fotossíntese no dossel, enquanto a qualidade da radiação é a variável que regula a morfologia da planta. Ambos os componentes são modificados numa situação de competição no consórcio, em comparação ao monocultivo e, como conseqüência, alterase a acumulação de biomassa, a produção de grãos e a morfologia das espécies consorciadas (Baumann et al. 2001). Nos cultivos consorciados as espécies normalmente diferem em altura e em distribuição das folhas no espaço, entre outras características morfológicas que podem levar as plantas a competir pela radiação fotossinteticamente ativa (RFA), isto é, a radiação utilizada pelas plantas.

Plantas que crescem sob ou dentro do dossel de outras culturas são expostas à reduzida quantidade de RFA e também recebem radiação de qualidade diferente daquela recebida pelas que crescem em pleno sol. A radiação no interior do dossel, 
especialmente nas camadas mais baixas, é enriquecida pela radiação vermelho-distante (700-740 nm), que segundo Holt (1995), é a radiação resultante da absorção seletiva da radiação encontrada no espectro vermelho (660-670 nm) dos pigmentos fotossintéticos e da reflexão e transmissão da radiação vermelho-distante pelas folhas verdes. Dessa maneira, a relação vermelho-distante - vermelho (VD/V) da radiação nas camadas inferiores do dossel é superior àquela encontrada sobre o dossel das culturas consorciadas.

A maior relação VD/V nas plantas, é um indicativo de competição, pois induz a maior alocação de fotoassimilados para o desenvolvimento das folhas e dos ramos em detrimento do sistema radicular (Salisbury \& Ross, 1991).

De acordo com Wallace et al. (1991), uma importante característica da cultura do milho refere-se a maior parte da RFA ser capturada na camada superior do dossel, pelas folhas mais jovens e eficientes, e menos de $10 \%$ da RFA incidente chega a atingir as camadas inferiores do dossel abaixo de 1,0m. Assim, a competição direta pela RFA incidente é desfavorável às culturas dominadas no dossel do milho. Além disso, o milho possui habilidade competitiva devido aos diferentes materiais genéticos disponíveis quanto a altura, IAF, ângulo foliar e taxas de crescimento (Begna, 2001).

O índice de área foliar (IAF) representa a quantidade de área foliar por unidade de área de solo, sendo a característica mais utilizada na descrição das relações entre a radiação e o dossel das culturas. O IAF também define a habilidade do dossel de determinada cultura em interceptar a RFA incidente, sendo um importante fator na determinação do acúmulo de biomassa pelas plantas. O IAF das espécies cultivadas também pode ser reduzido pela alta pressão de competição exercida pelas plantas daninhas, notadamente gramíneas $\mathrm{C}_{4}$, afetando diretamente a produção e comprometendo a integridade deste sistema.

Silva et al. (2004), avaliando a evolução do IAF de milho e B. brizantha, em consórcio e monocultivo, notaram rápido desenvolvimento foliar da cultura em comparação à forrageira. A B. brizantha quando consorciada, apresentou menor IAF do 
que em monocultivo, onde o IAF máximo foi de 5,6 aos 133 DAE, enquanto o milho consorciado ou solteiro, apresentou IAF máximo de $4,38 \mathrm{~m}^{2}$ de folhas por $\mathrm{m}^{2}$ de solo, aos 83 DAE.

Segundo Dias Filho (2000 e 2002), a B. brizantha apresenta determinada plasticidade fenotípica e tolerância em resposta ao sombreamento, porém reduz sua capacidade fotossintética. Em ambiente sombreado, essa mesma espécie apresenta maior área foliar específica, maior razão de área foliar e menor relação entre clorofila a e b, economizando o nitrogênio necessário à captura de luz, bem como baixo ponto de compensação luminoso, promovendo um balanço positivo de carbono para manutenção do seu crescimento. Assim, a produtividade do milho é favorecida e viabilizada pela baixa competição exercida pela $B$. brizantha no consórcio. Além disso, uma das condições necessárias para se obter vantagens potenciais na associação de gramíneas forrageiras cultivadas com culturas anuais, visando a formação de pastagens, é a utilização de forrageiras com tolerância ao sombreamento.

\subsubsection{Competição por nutrientes}

A interferência das forrageiras no estado nutricional e rendimento de grãos da cultura principal dependem das condições edáficas e climáticas dos cultivares utilizados e do manejo empregado (Silva et al., 2004).

O tipo e a disponibilidade do nutriente influenciam a competição por este fator, assim como a eficiência de uso da água pelas plantas e a quantidade de chuva afetam a competitividade das culturas. A disponibilidade do nitrogênio $(\mathrm{N})$ no solo e sua distribuição na planta podem ser alteradas pela presença do competidor durante o crescimento e desenvolvimento do milho (Rajcan \& Swanton, 2001). Desta maneira, segundo Tollenaar et al. (1994), sob alta competição ocorre a diminuição da concentração de clorofila nas folhas, reduzindo a taxa fotossintética, o acúmulo de biomassa e a produção de grãos.

Para Machado (2001), o N é o nutriente que mais limita o crescimento da pastagem, sendo que a falta deste nutriente é considerada um dos principais fatores que 
levam a degradação do sistema. $\mathrm{O} \mathrm{N}$, além de atuar sobre a sustentabilidade da comunidade de plantas, torna-se também o principal modulador da produtividade agrícola, em sistema de produção. Assim, quando o suprimento de $\mathrm{N}$ no solo não é adequado para atender às exigências da planta, a produção de forragem é substancialmente reduzida (Boddey, 1996).

A adição de nitrogênio a partir da atmosfera (geralmente em quantidades inferiores a 10 kg N.ha-1), juntamente com o N disponibilizado a partir da mineralização da matéria orgânica e da decomposição de resíduos de origem animal e vegetal, pouco auxiliam no atendimento das exigências de N da planta forrageira. Boddey et al. (1996), estimaram que pastagens solteiras nos Cerrados apresentariam um déficit de nitrogênio, considerando apenas a ciclagem de nutrientes, da ordem de $58 \mathrm{~kg} \mathrm{~N} \mathrm{ha}^{-1}$. ano ${ }^{-1}$.

Alvim et al., (1990), avaliando a produção de matéria seca (MS) de 5 acessos (amostra de germoplasma representativa de um ou vários indivíduos de uma população) de capim-braquiária e diferentes doses de $\mathrm{N}$, verificaram que a produção anual de matéria seca de todos os acessos responderam aos níveis de N aplicado (0; 75 e $150 \mathrm{~kg}$. $\mathrm{ha}^{-1}$ ), sendo a $B$. brizantha a espécie que mostrou maior potencial de produção de matéria seca e a maior eficiência relativa em relação as demais gramíneas, para as doses de N utilizadas. Entretanto, na ausência deste elemento, esta espécie foi a que produziu menor quantidade de matéria seca, enquanto que a espécie $B$. decumbens foi a mais produtiva. B. ruziziensis e $B$. humidicola mostraram-se mais sensíveis às condições climáticas adversas ao crescimento da planta.

O teor de fósforo (P) no solo é um dos fatores mais limitantes da produção forrageira em pastagens, especialmente naquelas onde não são realizadas adubações de manutenção. Isto é em função de sua baixa biodisponibilidade, tanto pelo seu nível de reserva como pela elevada capacidade de retenção de fosfatos pelo solo. Deste modo, o fósforo é responsável pela rápida queda da capacidade produtiva das pastagens cultivadas, comprometendo a sustentabilidade do sistema. 
Martinez (1980) testou níveis críticos de fósforo em sete espécies de gramíneas tropicais e concluiu que a Brachiaria humidicola e a Hyparrhenia rufa foram as espécies mais eficientes na absorção e utilização desse nutriente. Em ordem decrescente, seguiram-se as espécies Pennisetum purpureum, Panicum maximum, Digitaria decumbens, Brachiaria decumbens e Melinis minutiflora.

Em trabalho semelhante Nunes et al. (1985), constataram que o P. maximum, cultivar Marandu, tem boa resposta a adubação fosfatada, aumentando a produção de matéria seca, de 8,6 para $20 \mathrm{t} \mathrm{ha}^{-1}$, com a aplicação de $400 \mathrm{~kg} \mathrm{P} \mathrm{ha}{ }^{-1}$. O mesmo cultivar apresenta ainda boa tolerância a altos níveis de alumínio e manganês no solo, não respondendo significativamente a calagem. A aplicação de calcário, no entanto, não deve ser descartada, devido ao fornecimento de cálcio e magnésio ao solo.

Sanchez \& Salinas (1987), concluíram que existem diferenças entre espécies cultivadas e variedades dentro da mesma espécie na tolerância a baixos níveis de $\mathrm{P}$ disponível no solo. A informação levantada sugere que as espécies ou variedades mais tolerantes a baixos níveis de $\mathrm{P}$ disponível têm rendimentos mais altos em baixos níveis de P aplicado do que as espécies ou variedades mais sensíveis. Os níveis críticos para as espécies forrageiras tropicais são, provavelmente, mais baixos do que para as culturas anuais (Lobato et al., 1985).

Em experimento conduzido por Corrêa \& Haag (1993 a), em casa de vegetação, não foram constatadas diferenças entre $B$. brizantha e $B$. decumbens quanto à exigência de P para o estabelecimento das gramíneas. Entretanto, quando o mesmo experimento foi instalado em condições de campo (Corrêa \& Haag, 1993 b), a B. brizantha apresentou-se mais exigente em Fósforo que a variedade $B$. decumbens. Os níveis críticos de Fósforo na planta também foram variáveis entre as espécies, sendo os maiores teores verificados na B. brizantha.

Premazzi (1991), submetendo B. brizantha a níveis crescentes de saturação por bases, com a finalidade de se determinar o nível que possibilita na maior produção de matéria seca, concluiu que 43\% de saturação proporcionou a máxima produção. Em 
relação à parte aérea e raízes, os nutrientes que melhor caracterizaram o efeito do tratamento no solo foram cálcio e magnésio, cujos teores aumentaram, e manganês e zinco, cujos teores diminuíram em função dos níveis de saturação por bases. Assim, a correção da acidez e a suplementação de $\mathrm{Ca}^{2+}$ e $\mathrm{Mg}^{2+}$ para as plantas são fundamentais para a produção de grãos e forragem em solos ácidos.

Com relação aos micronutrientes, Mattos \& Colozza (1986), salientam que pastagens apresentam resposta significativa à adubação com micronutrientes somente quando são supridas as necessidades dos macronutrientes, especialmente o $\mathrm{P}$, na fase de estabelecimento e o nitrogênio, em cobertura. Assim, em sistemas consorciados com pastagens, o fornecimento de micronutrientes pode se constituir em importante fator de garantia para a obtenção de produtividades satisfatórias das espécies envolvidas.

A adubação, realizada com o objetivo de minimizar a competição por nutrientes, pode ser eficiente em alguns casos, porém pode agravar o problema se mal empregada. De acordo com Fleck (1992), adubações em grande quantidade, por aumentarem tanto o crescimento das espécies infestantes quanto da cultura, intensificam a competição, beneficiando a espécie mais eficiente no uso desse recurso.

Sistemas consorciados são viáveis quando as plantas associadas possuem período de crescimento similar, porém com picos de demandas de nutrientes em fases distintas, atendendo as exigências das plantas, não excedendo a taxa pela qual os nutrientes podem ser supridos pelo solo (Willey, 1979).

\subsubsection{Alelopatia}

Entre plantas, a competição por elementos vitais como água, luz, nutrientes e dióxido de carbono $\left(\mathrm{CO}_{2}\right)$ é bastante conhecida, mas além dela, algumas plantas podem exercer uma inibição química sobre a germinação e o crescimento de outras, conhecida por alelopatia ou efeito alelopático. (Lorenzi, 1982).

Algumas espécies produzem substâncias alelopáticas que podem provocar: a) redução na germinação, b) deformação e morte de plântulas, c) diminuição na absorção e 
eficiência de nutrientes, d) redução no crescimento e no perfilhamento de plantas e e) diminuição da produtividade (Rice, 1984; Hale \& Orcutt, 1987; Rodrigues et al., 1993).

Os compostos químicos com potencial alelopático estão presentes em quase todos os tecidos da planta, incluindo folhas, caules, raízes, rizomas, flores, frutos e sementes. As plantas podem sintetizar mais de uma substância tóxica, e esta, por sua vez, pode ter mais de uma função (Almeida, 1988).

Até o momento, não se conhece, detalhadamente, todos os produtos químicos com propriedades alelopáticas, nem tampouco a forma como são sintetizados. Dentre as substâncias de maior ocorrência estão os ácidos fenólicos, terpenóides, cumarinas, flavonóides, ácido felúrico, juglona, taninos, ácido gálico, ácido vanílico, ácido cinâmico, escopoletina e vários glicosídeos (Wittaker \& Feeny, 1971; Rice, 1984; Almeida, 1988 e Rodrigues et al., 1992).

\subsubsection{Efeitos da alelopatia na consorciação}

O estudo da alelopatia em pastagens é complexo em função da natureza das interações observadas. Desta maneira, a compactação do solo pelo pisoteio, a deposição irregular de excrementos dos animais na área e do pastejo seletivo pelos animais poderia causar o aumento de espécies menos palatáveis ou o desaparecimento de espécies menos tolerantes ao pastejo, sem que efetivamente ocorra algum efeito que possa ser atribuído à alelopatia (Rodrigues et al., 1993).

Informações sobre a alelopatia em pastagens são ainda incipientes, no entanto o reconhecimento do potencial desses efeitos é extremamente importante para permitir a adoção de práticas agronômicas, que possibilitem êxito no estabelecimento de outras plantas no consórcio com plantas forrageiras.

Assim sendo, o conhecimento aprofundado dos efeitos alelopáticos em culturas consorciadas poderia ser utilizado para controlar o banco de sementes ou para estimular a germinação uniforme dessas sementes, de maneira a reduzir o uso potencial de herbicidas. 
O estabelecimento de pastagens consorciadas em diversos locais do Brasil, muitas vezes, não tem obtido sucesso e este fato tem sido atribuído às dificuldades de manejo de plantas com exigências fisiológicas e taxas de crescimento diferentes. Entretanto, nesse caso em particular, não se pode desconsiderar a hipótese de que as dificuldades de estabelecimento e a falta de persistência, de um dos componentes da pastagem consorciada estejam ligados a incompatibilidade das espécies, em função de efeitos alelopáticos. Desta forma, antes de se recomendar sistemas consorciados de produção, seria recomendável a avaliação do potencial alelopático das espécies consideradas (Rodrigues et al., 1992). Neste contexto, diversos trabalhos demonstram que espécies de capim-braquiária possuem propriedades alelopáticas, que interferem no desenvolvimento de muitas espécies consorciadas (Chou, 1977; Chou et al., 1989; Stanizio et al., 1991).

\subsection{Importância, histórico e descrição das plantas forrageiras utilizadas na experimentação}

\subsubsection{Importância e histórico de gramíneas e leguminosas}

Não pairam dúvidas de que as espécies de plantas da família botânica Poaceae (popularmente conhecidas como gramíneas) são as mais importantes espécies no aspecto científico e econômico. Elas são proeminentes no recorde absoluto de distribuição completa e constituem uma excelente fonte para estudos taxonômicos, históricos e geográficos, podendo, seus representantes, ser encontrados nas mais diversas altitudes e latitudes e seu grau de distribuição nas regiões é denso e contínuo (Alcântara \& Bufarah, 1999). Por outro lado, os mesmos autores citam ainda que, as gramíneas possuem uso tradicional e bastante difundido na atividade pecuária, e que estas são exigentes do fertilizante nitrogenado e transformam-no com rapidez em proteína de folha, que servirá ao ruminante de matéria-prima na formação de carne, leite, lã e peles.

Já as leguminosas, apesar de constituírem há tempos fonte de alimentos protéicos para o homem, somente de alguns anos para cá vêm assumindo posição de destaque na alimentação animal, sendo hoje em muitos países, consideradas por grande número de 
pesquisadores como as representantes de maior importância numa pastagem chegando, em algumas situações, a deslocar as tradicionais gramíneas para segundo plano (Alcântara \& Bufarah, 1999). Também, segundo estes autores, no Brasil, sua introdução de data recente vem ocupando pesquisadores e pecuaristas com sua experimentação, mas ainda a situação encontrada está muito aquém da solução final do complexo pastagem.

As leguminosas são plantas complexas e conseguem fixar o nitrogênio elementar que compõe a atmosfera, por meio da fixação simbiótica das bactérias dos nódulos de Rhizobium e Bradyrhizobium, unidade do conjunto simbiótico encarregado de fixar o $\mathrm{N}$ do ar. Desta forma, o sistema do pasto se enriquece, e além das leguminosas, os capins e as culturas subseqüentes também se beneficiam do N (Primavesi, 1986; Azcón, 1991; Alcântara \& Bufarah, 1999; Ambrosano, 1999 e 2001).

O histórico, as origens, descrições morfológicas e características agronômicas das forrageiras, empregadas como adubos verdes, que foram utilizadas nesta experimentação, foram descritas por Alcântara \& Bufarah (1999).

\subsubsection{Brachiaria brizantha (Hochst. ex A. Rich.) Stapf.}

Nome comum: brizanta, “palisade grass”.

Origem: África Tropical e África do Sul.

Descrição morfológica: gramínea rizomatosa, perene, com folhas eretas e largas, levemente pilosas ou glabras, de coloração verde-escura, com margens ásperas; inflorescência racemosa com 2,5 a 16 cm de comprimento e possuindo racemos de 2 a 8 cm com espiguetas pediceladas e em fila única ao longo dos mesmos. Espiguetas sem cerdas e quase glabras com duas floretas das quais só a superior é fértil.

Características agronômicas: gramínea largamente distribuída em regiões mais ou menos úmidas $(760 \mathrm{~mm})$ do nível do mar até mais de $2.000 \mathrm{~m}$ de altitude, resistente à seca, cresce bem tanto em solos secos e úmidos.

É uma espécie promissora para pastagem e fenação, sendo muito apreciada pelos animais, principalmente os brotos novos. Na Rodésia, quando madura, é atacada por 
uma doença foliar que a torna não palatável. Permite a associação com soja perene, siratro, além de outras leguminosas subarbustivas e produz cerca de 8 a 10 ton. ha ${ }^{-1}$.ano ${ }^{-1}$ de matéria seca.

Propagação: propaga-se por rizomas e por sementes provenientes de apomixia que possuem baixo poder germinativo.

\subsubsection{Brachiaria decumbens Stapf. Prain.}

Nome comum: braquiária, "signal grass”, decumbens.

Origem: Capim africano introduzido no Brasil através do IPEAN (Atual EMBRAPA). Originário do platô dos Grandes Lagos na Uganda.

Descrição morfológica: gramínea de hábito decumbente, bastante enfolhada, formando denso relvado de até $70 \mathrm{~cm}$ de altura. Folhas muito pubescentes e inflorescências racemosa contendo racemos com fila dupla de sementes também pubescentes, ráquilas em zigue-zague e finas.

Características agronômicas: gramínea de origem africana, com exigência média em solos, adaptando-se àqueles argilosos ou arenosos e de profundidade razoável. Adaptada a áreas tropicais úmidas $\left(18\right.$ a $28{ }^{\circ} \mathrm{C}$ e 1.100 a $1.400 \mathrm{~mm}$ de chuva.ano $\left.{ }^{-1}\right)$ com estação seca de 4 a 5 meses; responde visivelmente à fertilização nitrogenada.

Cresce bem no verão, porém tem sua produção afetada por baixas temperaturas, sofrendo bastante com a ocorrência de geadas.

Produz cerca de 9 a 11 ton. ha ${ }^{-1}$.ano ${ }^{-1}$ de matéria seca em 4 cortes; presta-se bem para a fenação e pastejo contínuo, sendo, porém, de difícil associação com leguminosas, devido a seu hábito prostrado de crescimento que impede o estabelecimento de outras forrageiras. Uma tentativa que poderá dar bons resultados seria o emprego de leguminosas arbustivas e subarbustivas, semeadas em linha nos pastos de B. decumbens. Para tanto poderiam ser usadas: Leucaena leucocephala, Desmanthus virgatus, Indigoflora endecaphylla e Cajanus cajan. 
Vários problemas têm surgido com relação às braquiárias, sendo que a $B$. decumbens apresentou em algumas regiões dos estados de São Paulo, Minas Gerais, Goiás e Mato Grosso fotossensibilização em bovinos que se alimentavam em pastos dessa gramínea.

Posteriormente, foi determinado o agente infeccioso que é o fungo Phytomyces chartarum, também encontrado em diversas outras gramíneas, porém só aqui causando a sintomatologia da sensibilização.

Entretanto, tomando-se os cuidados preconizados pelas instituições credenciadas para este fim, a doença pode ser evitada. Dentre tais precauções citam-se: não permitir que animais com menos de 20 meses de idade e vacas lactantes tenham acesso à pastagem de $B$. decumbens; fazer rodízio de pastagens; manter o relvado baixo; aplicar dessensibilizantes; levar os animais atacados à sombra e manter a espécie em cerca de 25 a 30\% da área total da pastagem.

Propagação: por rizomas ou por sementes que necessitam de um período aproximado de 12 meses de armazenamento antes do plantio. No entanto, a germinação de sementes recém-colhidas pode ser melhorada com tratamento químico de 15 minutos em ácido sulfúrico comercial concentrado. Após lavagem em água corrente, seu poder de germinação aumenta sensivelmente. A reprodução é apomítica e o número cromossômico $4 \mathrm{n}=36$. Apresenta aproximadamente 450.000 sementes por quilo. A produção de sementes no cultivar australiano chega a $150 \mathrm{~kg}^{-h^{-1}}$ enquanto que no cultivar comum é menor.

\subsubsection{Panicum maximum Jacq.}

Nome comum: capim-colonião.

Origem: África.

Descrição morfológica: planta perene densamente estufada, com rizomas grossos, colmos eretos atingindo até $4 \mathrm{~m}$ de altura e possuindo em geral 6 nós pilosos e exertos. 
Folhas verdes claras, lâminas lineares pontiagudas com arredondamento na base junto à bainha e comprimento de $100 \mathrm{~cm}$ em geral por 1 a 3,5cm de largura; nervuras verde-escuras; lâmina fortemente quilhada com até 7 nervuras subprincipais, brancas, colocadas de cada lado da nervura principal, acuminada e com margens serreadas e levemente pilosas.

A inflorescência é uma panícula cônica aberta com ramos principais e arranjos em espiral com até 40 x $40 \mathrm{~cm}$.

Espiguetas todas semelhantes, isoladas e associadas em pares desiguais, segundo pedúnculo, possuindo 2,5 a 4,0mm de comprimento, sendo a flor inferior masculina ou neutra e a flor superior hermafrodita com 3 anteras amadurecendo antes da flor inferior.

Características agronômicas: é uma das principais forrageiras da América Tropical cultivada em larga escala. Capim bastante agressivo de difícil associação com leguminosas possui boa resistência ao pastoreio e ao fogo. É uma gramínea muito exigente em fertilidade de solo, preferindo terras profundas, friáveis e levemente arenosas.

Vegeta bem em locais quentes onde a precipitação está acima de $900 \mathrm{~mm}$ ao ano. É muito aceito pelos animais no estado verde que constitui sua principal via de utilização, mas pode ser dado fenado ou ensilado, porém devido a grossura de seus colmos geralmente não produz bom feno. Sua produção varia muito segundo a fertilidade do solo, encontrando-se dados de 8 a 13 ton.ha ${ }^{-1}$.ano ${ }^{-1}$ de matéria seca ou de 40 a 60 ton.ha ${ }^{-1}$.ano ${ }^{-1}$ de matéria verde com cerca de 8,4\% de proteína bruta.

Possui elevada capacidade de suporte desde que se observe um manejo adequado, sendo que, em geral, a altura indicada como razoável seria manter a vegetação a 30 - 35cm em média. Pode ser associado a leguminosas agressivas, como a soja perene, siratro e kudzu tropical.

Propagação: por meio de sementes que produz abundantemente (cerca de 180 kg. ha ${ }^{-1}$ ) usando-se 3 a 5 kg. ha ${ }^{-1}$ quando o valor cultural se encontra próximo de $24 \%$ ou $16 \mathrm{~kg} \mathrm{ha}^{-1}$ quando o valor cultural das sementes estiver com $10 \%$ de valor cultural. 
Pode-se propagar por mudas enraizadas ( 1 x 1 ou 2 x 2 ) ou por estacas. Produz sementes por via apomítica embora haja presença de sexualidade (em torno de 20\%) sem que se saiba ainda se ocorre autopolinização ou fecundação cruzada. As sementes recém colhidas possuem certa dormência, necessitando, assim, um período de armazenamento para melhorar sua germinação. São freqüentemente atacadas por doenças causadas em nosso meio pelo fungo do gênero Ustilago (carvão) e pelo Claviceps paspali.

\subsection{Importância, histórico e descrição das plantas daninhas utilizadas na experimentação}

As considerações sobre as plantas daninhas utilizadas no experimento foram feitas por Kissmann (1992 e 1997).

\subsubsection{Ipomoea grandifolia (Dammer) O Don.}

\section{Código: IAQGR}

Sinônimos: Jacquemontia grandifolia Dammer; Ipomoea triloba var. genuína Meissn.

Origem do nome: grandifolia - As folhas são relativamente grandes, em relação ao tamanho das flores.

Nomes vulgares: corriola, corda-de-viola, campainha, jetirana.

Aspectos taxonômicos: Planta muito variável quanto ao formato das folhas, o que tem causado enormes dificuldades nas identificações. O especialista Daniel F. Austi (1978), considerou tratar-se de um híbrido entre Ipomoea cordato-triloba e Ipomoea batatas e por isso o nome foi acrescido de um X - Ipomoea X grandifolia. Em 1992, entretanto o mesmo autor voltou atrás, pois examinando as sementes concluiu não ser possível essa hibridação, uma vez que as sementes de I. grandifolia são menores que as de ambas as espécies tidas como cruzadas; sementes de híbridos conhecidos, dentro da Seção Batatas são sempre maiores. 
Origem e distribuição: Planta nativa na América do Sul, ocorrendo na Argentina, Uruguai, Paraguai e Brasil, onde tem sido a espécie de Ipomoea mais comum, como infestante em lavouras.

\section{Importância econômica:}

a) Positiva: É uma planta atraente pelo seu intenso florescimento, mas raramente é usada como ornamental.

b) Negativa: Infestante em lavouras, notadamente em culturas anuais de verão nas regiões Sul, Sudeste e Centro-Oeste do Brasil. Como o ciclo termina depois da maturação das culturas, tende a criar um problema na colheita, quando a infestação é significativa, pois seus ramos se emaranham nas plantas da cultura.

Biologia: Planta anual, reproduzida por semente. Na parte meridional do Brasil a germinação ocorre intensamente a partir do fim do inverno e o ciclo até a maturação pode ser de 150 - 180 dias nessas condições, reduzindo-se a 120 dias quando a germinação ocorre no verão. Após a maturação as sementes apresentam geralmente pronta viabilidade. Quando a planta se encontra em local úmido, como em lavoura irrigada, as sementes podem germinar enquanto ainda se encontram nos frutos, na planta. No solo a germinação ocorre até uma profundidade de $10 \mathrm{~cm}$, mas abaixo de alguns centímetros há certa demora para o início do processo germinativo.

A planta prefere solos modificados, como os de uso agrícola. Tem sido a espécie mais freqüente em lavouras de interesse comercial, ocorrendo também em áreas abandonadas.

Morfologia: Planta herbácea de caule e ramos volúveis que se emaranham em plantas vizinhas ou crescem sobre obstáculos. Indumento: pêlos simples alvotranslúcidos nos ramos, folhas e cálices, com raiz principal pivotante e dispersão via sementes. 
Caracterização da espécie: Ocorrem várias espécies de Ipomoea no Brasil, que apresentam flores muito semelhantes quanto ao formato, tamanho e coloração das corolas. As folhas, sendo geralmente muito irregulares, não são elementos importantes na separação de espécies. Uma planta morfologicamente muito semelhante é Ipomoea cordado-triloba, no entanto, as sementes são maiores.

\subsubsection{Amaranthus hybridus L.}

\section{Código: AMACH}

Sinônimos: Amaranthus clorostachys Willd.; Amaranthus quitensis H.B.K.; Amaranthus incurvatus Tim

Origem do nome: hybridus - Do latim, significando híbrido (provavelmente porque as plantas apresentam características isoladas de diversas outras espécies).

Nomes vulgares: caruru, caruru-gigante, bredo, bredo-gigante.

Aspectos taxonômicos: A. hybridus não é um híbrido, mas uma planta altamente polimorfa. Diversos autores têm subdividido essa espécie, usando principalmente características de coloração das inflorescências e tamanho relativo das brácteas e tépalas nas flores femininas.

A situação difere nas diversas regiões geográficas do mundo e mesmo no Brasil temos visto plantas em estágios intermediários, quanto à coloração das panículas e outros órgãos. Por outro lado, na região oeste do estado do Paraná, praticamente não se encontram os tipos intermediários, havendo forte presença dos dois tipos de plantas: $A$. hybridus L. var. paniculatus (L.) Thell. e A. hybridus L. var. patulus (Betol.) Thell., ambas apresentadas por Lorenzi (1982).

Origem e distribuição: Espécie encontrada nas Américas, do Canadá à Argentina. Presente também na África, Ásia e Oceania. No Brasil está presente em quase todo o território nacional, havendo, contudo maiores concentrações em certas regiões, como por exemplo, o norte e o oeste do Paraná e depressão central do Rio Grande do Sul. 
Morfologia: Plantas eretas com porte variável conforme as condições durante a fase de crescimento, podendo chegar a 1,50 ou mesmo 2,0 m de altura. Ocorre uma grande variação de tipos, especialmente com referência à coloração das inflorescências, que podem ser verdes ou vermelho arroxeadas. Também no resto da planta a presença de pigmentação avermelhada é extremamente variável. O caule geralmente é ereto, com raiz principal pivotante e bastante desenvolvida, tendo as sementes como unidades de dispersão.

Caracterização da espécie: $O$ aspecto das plantas, especialmente a coloração das espigas, mas também dos caules e folhas, é muito variável e freqüentemente induz a confusões. As plantas não têm espinhos. A coloração pode ser totalmente verde, mas pode ser preponderantemente avermelhada ou purpúrea, contudo sempre existem tecidos clorofilados, isto é, verdes. Inflorescências terminais em forma de espiga ou panícula. Frutos transversalmente deiscentes, igualando ou exercendo em altura as tépalas.

\subsubsection{Digitaria horizontalis Willd.}

Código: DIGHO

Sinônimos: Digitaria setosa Desv.; Panicum horizontalis G. Meyer

Origem e distribuição: Planta nativa nas regiões da América e da África onde, na costa ocidental, é a espécie mais freqüente de Digitaria. No Brasil é muito comum, sendo predominante na região Sudeste.

Nomes vulgares: capim-colchão, colchão.

Biologia: Planta anual reproduzida por semente, alastrando-se por enraizamento a partir de nós dos colmos em contato com o solo. Aprecia solos férteis, cultivados ou não, sendo pouco agressiva em solos pobres. É uma das primeiras infestantes a aparecer após o preparo do solo, na primavera. Encerra o ciclo antes de culturas como milho e soja.

Morfologia: Quando isolada ou em espaço aberto tende a estender os ramos sobre o solo, em todos os sentidos, a partir da base, elevando apenas a parte terminal 
com a inflorescência. A altura fica geralmente entre 30-60 cm. Indumento de pêlos curtos e alvos, distendidos sobre bainhas e, de forma escassa, sobre a face dorsal das lâminas foliares. Colmos cilíndricos e finos, geralmente com 2-3 mm de espessura. Ausência de rizomas, apresentando raízes fasciculadas a partir da base e raízes adventícias a partir de alguns nós em contato com o solo úmido. As unidades de dispersão são as cariopses, geralmente conservando as glumas.

Caracterização da espécie: Entre as espécies de Digitaria, $D$. horizontalis se distingue por apresentar nos racemos, junto à base de cada espigueta, um longo pêlo branco de base tuberculada. 


\section{MATERIAL E MÉTODOS}

A pesquisa foi conduzida em área experimental do Departamento de Produção Vegetal da Escola Superior de Agricultura "Luiz de Queiroz", campus da USP/ESALQ, em Piracicaba - SP, cujo município apresenta as seguintes coordenadas geográficas: altitude de $546 \mathrm{~m}$, latitude de $22^{\circ}$ e $42^{\prime}$ e $30^{\prime}$ ' Sul e longitude de $47^{\circ}$ e $30^{\prime} \mathrm{W}$. O clima da região é o tipo Cwa, segundo a classificação de Koeppen, isto é, trata-se de clima mesotérmico, tropical úmido, com 3 meses mais secos (junho, julho e agosto) e com concentração de chuvas no verão. De acordo com o Departamento de Ciências Exatas da USP/ESALQ, a temperatura média do mês mais quente está acima de $24^{\circ} \mathrm{C}$ e a do mês mais frio abaixo de $17^{\circ} \mathrm{C}$, apresentando uma precipitação pluvial média anual de 1200 $\mathrm{mm}$.

\subsection{Experimento de campo}

Foi conduzido no período de dezembro de 2003 a maio de 2004, em solo classificado como Nitossolo vermelho (eutroférrico chernossólico) (EMBRAPA, 1999). A análise das propriedades químicas deste solo foi realizada pelo Laboratório de Análises de Solos do Departamento de Solos e Nutrição Mineral de Plantas da Escola Superior de Agricultura “Luiz de Queiroz”, cujos resultados são apresentados na tabela 1. 
Tabela 1. Resultados da análise química de solo da área experimental do experimento de campo, Piracicaba, SP

\begin{tabular}{|c|c|c|c|c|c|c|c|c|c|c|}
\hline pH & $\begin{array}{l}\text { M.O.S. } \\
\left(\text { g.dm }^{-3}\right)\end{array}$ & $\mathbf{P}$ & $\begin{array}{c}S \\
\mathbf{d m}^{-3}\end{array}$ & $\mathbf{K}$ & Ca & $\begin{array}{r}\text { Mg } \\
\text { (mI }\end{array}$ & $\begin{array}{l}\mathbf{H}+\mathbf{A l} \\
\left.\mathbf{d m}^{-3}\right)\end{array}$ & SB & $\mathbf{T}$ & $\begin{array}{c}\mathrm{V} \\
(\%)\end{array}$ \\
\hline 5,1 & 19 & 13 & 57 & 3,8 & 40 & 12 & 28 & 55,8 & 83,7 & 67 \\
\hline
\end{tabular}

Os dados climatológicos relativos ao período experimental são apresentados na tabela 2 e foram coletados no posto meteorológico automatizado pertencente ao Departamento de Ciências Exatas da USP/ESALQ, instalado no Campus da ESALQ, em Piracicaba, SP.

Tabela 2. Dados climatológicos relativos ao período de condução do experimento (dezembro de 2003 a maio de 2004), Piracicaba, SP

\begin{tabular}{lcccccc}
\hline \multirow{2}{*}{ ANO } & MÊS & Precipitação & UR & T. máx. & T. mín. & T. média \\
& & & média & média & média & \\
\multirow{2}{*}{2003} & Dez. & 139,9 & 84 & 30,4 & 19,4 & 24,9 \\
& Jan. & 196,4 & 83 & 29,2 & 18,7 & 23,1 \\
& Fev. & 194,0 & 86 & 29,6 & 18,4 & 24,0 \\
& Mar. & 79,1 & 83 & 29,5 & 17,3 & 23,4 \\
& Abr. & 92,3 & 83 & 29,0 & 17,1 & 23,0 \\
& Mai. & 105,9 & 89 & 24,3 & 12,8 & 18,6 \\
\hline
\end{tabular}

O delineamento experimental adotado foi o de blocos casualizados com parcelas subdivididas, utilizando dois fatores de estudo, ou seja, plantas forrageiras e plantas daninhas, da seguinte forma: plantas forrageiras (quatro níveis) - Brachiaria decumbens, Brachiaria brizantha; Panicum maximum e sem planta forrageira x plantas daninhas (três fatores) - Ipomoea grandifolia, Amaranthus hybridus e Digitaria horizontalis, com 
3 repetições. No fator planta daninha $D$. horizontalis, foi utilizada a infestação natural da planta daninha existente na área, pois era a planta daninha dominante, sendo que as demais plantas daninhas foram semeadas. Além dos fatores planta forrageira e planta daninha onde a cultura do milho foi um fator constante, em todas as subparcelas foram instalados tratamentos adicionais considerados testemunhas, sem a cultura do milho, ou seja, as três espécies forrageiras sem a cultura do milho e sem plantas daninhas e testemunhas com as três espécies de plantas daninhas sem as culturas do milho e forrageiras. Também foram instaladas duas testemunhas com a cultura do milho solteiro (sem cultura forrageira) e sendo uma sem capina com a infestação natural de plantas daninhas (predominantemente capim-colchão) e outra onde foi capinada durante todo o ciclo, onde a cultura cresceu livre de qualquer interferência de plantas daninhas.

Cada subparcela constou de cinco linhas de milho espaçadas com 0,90m entre si, sendo que, cada entrelinha da cultura do milho era intercalada com 4 linhas das respectivas plantas forrageiras, sendo o comprimento da subparcela de 2,0m, portanto uma área total de 7,2 $\mathrm{m}^{2}$. Para coleta de resultados foram consideradas as duas linhas laterais da subparcela como bordadura.

O solo foi preparado com trator Massey Ferguson 275, através de uma roçagem e uma gradagem leve na profundidade de $20 \mathrm{~cm}$; uma escarificação na profundidade aproximada de $30 \mathrm{~cm}$ através de um escarificador tipo "lazer" de enxadinhas e uma gradagem niveladora na profundidade média de $10 \mathrm{~cm}$. A semeadura do milho foi realizada em linha, com semeadora tratorizada (marca Semeato), em espaçamento de 0,90m entre linhas e oito sementes/m linear. A semeadura das plantas forrageiras foi feita no mesmo dia da semeadura do milho e realizada manualmente nas entre linhas do milho, utilizando-se cerca de $10 \mathrm{~kg}$ de sementes por ha. Foi realizada uma adubação na

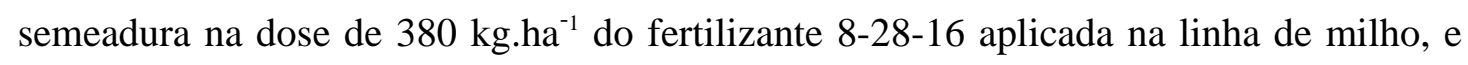
uma aplicação de nitrogênio em cobertura, na forma de sulfato de amônio, aos 40 dias

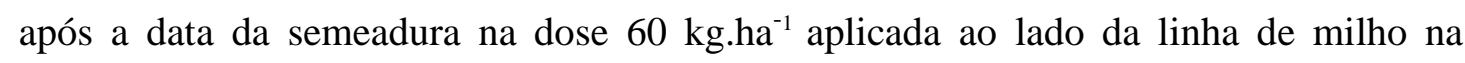
superfície. As semeaduras das plantas daninhas corda-de-viola e caruru foram feitas à lanço seguida de incorporação com enxada, enquanto que a planta daninha capim- 
colchão fazia parte da vegetação espontânea da área. Foram utilizadas $10 \mathrm{~g}$ de sementes de corda-de-viola e $10 \mathrm{~g}$ de sementes de caruru por subparcela de $7,2 \mathrm{~m}^{2}$, sendo que esta recomendação foi feita pela empresa Agrocosmos, que forneceu as sementes, baseada em testes de emergência das sementes no campo. A semeadura das plantas daninhas foi realizada também no mesmo dia da semeadura do milho.

Nas bordaduras do experimento, o mato foi controlado uma vez durante a condução do experimento, através do herbicida glyphosate $\left(480 \mathrm{~g} \cdot \mathrm{L}^{-1}\right)$ aplicado com pulverizador costal manual, com solução a $1 \%$ do herbicida e volume de calda de aproximadamente 300L.ha-1 ${ }^{-1}$ É importante mencionar também que, até o final de todas as avaliações, excetuando-se nas subparcelas dos tratamentos testemunhas da cultura do milho e das forrageiras, não ocorreu nenhum outro tipo de intervenção na área experimental.

A variedade de milho utilizada foi o cultivar CATI AL 34, com $87 \%$ de germinação, germinação mínima de $80 \%$, pureza de 99,9\%, peneira 22-C, onde se verificou um peso médio de cada 1000 sementes de 315,8g, sendo as sementes tratadas com o fungicida Ftalimida na concentração de $0,75 \mathrm{~g}$ de ingrediente ativo por kg de sementes, portanto numa concentração do ingrediente ativo nas sementes de $0,075 \%$.

As sementes das plantas daninhas corda-de-viola e caruru foram obtidas da empresa Cosmos Agrícola Produção e Serviços Rurais LTDA. (Agrocosmos), localizada no município de Artur Nogueira-SP e as sementes das plantas forrageiras foram obtidas na empresa Sementes Fortaleza, localizada no município de Campinas-SP.

As avaliações realizadas durante a condução do ensaio nas plantas daninhas foram as seguintes: (i) infestação das plantas daninhas I. grandifolia, A. hybridus e $D$. horizontalis, por meio da densidade (plantas. $\mathrm{m}^{-2}$ ), sendo que esta densidade foi avaliada através de um gabarito de madeira quadrado, medindo $0,5 \mathrm{~m}^{2}$, através de duas amostragens ao acaso nas subparcelas; (ii) massa seca em g.planta ${ }^{-1}$ e (iii) área foliar em $\mathrm{cm}^{2}$.planta ${ }^{-1}$. Estas avaliações de massa seca e área foliar foram realizadas através da colheita de três plantas em cada subparcela, manualmente e ao acaso, cortadas com o 
auxílio de uma tesoura de poda na superfícies do solo, sendo a área foliar avaliada imediatamente após o corte através do equipamento LI 7000, de acordo com a metodologia proposta por Benincasa (1988). Posteriormente, estas amostras foram colocadas em sacos de papel e secas em estufa a $50{ }^{0} \mathrm{C}$ durante 72 horas e em seguida pesadas, sendo que os resultados utilizados na discussão representam a média das três plantas avaliadas. Estas avaliações foram realizadas em intervalos de 14 dias, iniciando aos 14 dias após a semeadura da cultura do milho, num total de 12 avaliações.

As avaliações realizadas nas culturas forrageiras foram as seguintes: (i) matéria verde das plantas forrageiras (ton.ha ${ }^{-1}$ ), sendo para isso coletado todas as plantas incidentes em 1,0 metro linear, sendo este local de coleta selecionado ao acaso dentre as três linhas centrais da subparcela, desprezando-se a bordadura de $0,5 \mathrm{~m}$ no final da subparcela; (ii) massa seca em g.perfilho-1 e (iii) área foliar em $\mathrm{cm}^{2}$.perfilho ${ }^{-1}$. Estas avaliações de massa seca e área foliar foram realizadas através da colheita de três perfilhos em cada subparcela, manualmente e ao acaso, nas três linhas centrais, desprezando-se a bordadura, cortados com o auxílio de uma tesoura de poda na superfícies do solo, sendo a área foliar avaliada imediatamente após o corte através do equipamento LI 7000, de acordo com a metodologia proposta por Benincasa (1988). Posteriormente, estas amostras foram colocadas em sacos de papel e secas em estufa a $50{ }^{0} \mathrm{C}$ durante 72 horas e em seguida pesadas, sendo que os resultados utilizados na discussão representam a média das três plantas avaliadas. Estas avaliações foram realizadas em intervalos de 14 dias, iniciando aos 14 dias após a semeadura da cultura do milho, num total de 12 avaliações.

As avaliações realizadas na cultura do milho foram as seguintes: (i) rendimento em grãos da cultura (ton.ha ${ }^{-1}$ ), sendo que, para isso, após teste de umidade, foram colhidas as espigas das três linhas centrais, desprezando $0,5 \mathrm{~m}$ de bordadura no início e no final da subparcela; (ii) massa seca em g.planta ${ }^{-1}$ e (iii) área foliar em $\mathrm{cm}^{2} \cdot$ planta $^{-1}$. Estas avaliações de massa seca e área foliar foram realizadas através da colheita de uma planta em cada subparcela, manualmente e ao acaso, nas três linhas centrais, desprezando-se a bordadura, cortadas com o auxílio de uma tesoura de poda na 
superfícies do solo, sendo a área foliar avaliada imediatamente após o corte através do equipamento LI 7000, de acordo com a metodologia proposta por Benincasa (1988). Posteriormente, estas amostras foram colocadas em sacos de papel e secas em estufa a $50{ }^{0} \mathrm{C}$ durante 72 horas e pesadas, sendo que os resultados utilizados na discussão representam a média das plantas avaliadas. Estas avaliações foram realizadas em intervalos de 14 dias, iniciando aos 14 dias após a semeadura da cultura do milho, num total de 12 avaliações.

Os resultados da área foliar e biomassa seca das plantas foram analisados através de regressões não lineares, utilizando o programa estatístico TableCurve 2D (SYSTAT Software Inc., 2002) segundo o modelo logístico:

$$
y=a+\frac{b}{\left[1+\left(\frac{x}{c}\right)^{d}\right]}
$$

Onde: $y$ é a variável área foliar ou massa seca; $x$ é o coeficiente a época de avaliação; $a$ é o ponto mínimo da curva; $b$ é a diferença entre o ponto mínimo e o ponto máximo; $c$ é o tempo em dias necessário para que ocorra 50\% de resposta da variável; e $d$ é a declividade da curva (Seefeldt et al., 1995). Este tipo de equação tem sido utilizado adequadamente para representação de curvas de crescimento, pois os parâmetros da equação tem significado biológico. Segundo Benincasa (1988), a utilização de equações de regressão não só corrigem as oscilações normais, como permitem avaliar a tendência do crescimento em função dos tratamentos.

As avaliações dos outros parâmetros foram realizadas por meio de Análise de Variância com o auxílio do Programa de Análise Estatística SISVAR, sendo que as interações significativas tiveram suas médias comparadas entre si através do teste Tukey, ao nível de 5\% de probabilidade. Entretanto, os dados foram primeiramente transformados segundo $\sqrt{\mathrm{x}+0,5}$ para satisfazer a necessidade de distribuição normal dos resultados, no entanto os resultados aqui apresentados são originais, ou seja, sem transformação. 


\subsection{Experimento em casa-de-vegetação}

A partir do experimento de campo descrito no item anterior foram coletadas amostras de solo em cada uma das subparcelas (três amostras simples em cada subparcela para formar uma amostra composta), utilizando-se um trado de aço inoxidável de 4,3 cm de diâmetro e na profundidade de 0-10 cm. No momento da coleta das amostras de solo, realizada na terceira semana do mês de maio de 2004, as forrageiras estavam em pleno vigor vegetativo, bem como o milho já havia sido colhido.

Determinou-se o número de sementes viáveis não dormentes pelo método de germinação em bandejas, adotando-se o procedimento mencionado por Caetano (2000). De cada amostra composta de solo, retiraram-se quatro sub-amostras de 1,0 kg cada, que foram peneiradas (malha grossa - 0,280 mm), e colocadas em bandejas de alumínio com dimensões de 30 x 20 x 5 cm, formando uma camada de solo de aproximadamente $2 \mathrm{~cm}$ de profundidade. A partir da quarta semana de maio de 2004, as bandejas foram colocadas em casa-de-vegetação do Departamento de Produção Vegetal da Escola Superior de Agricultura "Luiz de Queiroz", campus da USP/ESALQ, em Piracicaba SP. Aos 30 e 60 dias após a instalação do experimento em casa-de-vegetação, foram realizadas avaliações das plântulas emergidas, retirando-as da bandeja, sendo feita a identificação por espécie e a contagem do seu número. O delineamento experimental utilizado foi o de blocos casualizados, com três repetições, e no esquema fatorial com dois fatores: a) forrageiras (4 fatores) Brachiaria decumbens, Brachiaria brizantha e Panicum maximum e área testemunha sem as forrageiras; b) plantas daninhas (três fatores) Ipomoea grandifolia, Amaranthus hybridus e Digitaria horizontalis num total de 36 parcelas. Não foram feitas amostragens nas testemunhas adicionais. O sistema de irrigação era composto por microaspersores, controlados por um "timer", tendo sido aplicado aproximadamente cinco mm por vez em quatro a cinco aplicações diárias. A casa-de-vegetação possuía ainda um sistema automático de controle de temperatura e umidade relativa, por meio de ventiladores, e a luminosidade foi controlada por cobertura de sombrite, automaticamente distendida conforme a luminosidade incidente. 
Os resultados obtidos foram analisados através da Análise de Variância, com o auxílio do Sistema de Análise Estatística - SISVAR, sendo que as interações significativas tiveram suas médias comparadas entre si pelo teste de Tukey, a 5\%. Para a análise estatística, os dados foram primeiramente transformados segundo $\sqrt{\mathrm{x}+0,5}$ para satisfazer a necessidade de distribuição normal dos resultados, no entanto, os resultados apresentados aqui são os originais, sem transformação. 


\section{RESULTADOS E DISCUSSÃO}

\subsection{Experimento de campo}

Na tabela 3, encontram-se os resultados obtidos de rendimento do milho em grãos (ton.ha ${ }^{-1}$ ), resultados da interação entre a infestação das três espécies de plantas daninhas e plantas forrageiras, além das testemunhas A e B capinadas e sem a capina, respectivamente, 150 dias após a instalação do experimento. Observa-se através destes resultados que o maior rendimento do milho, em comparação com a testemunha A (capinada), foi obtido no tratamento com $P$. maximum, seguido do tratamento com $B$. decumbens e B. brizantha, para as três espécies de plantas daninhas.

O fator infestação de diferentes espécies de plantas daninhas (I. grandifolia, A. hybridus e $D$. horizontalis) não afetou de forma significavamente diferente da produtividade de milho (não houve interação do fator plantas daninhas x culturas forrageiras), pois não existe diferença dentro das colunas em cada uma das forrageiras. No entanto, observa-se que o efeito das plantas daninhas foi bastante significativo na produtividade da cultura do milho, pois comparando as duas testemunhas (testemunha A e testemunha B) observam-se reduções significativas de produção, onde em média a testemunha capinada produziu 7,0 ton.ha ${ }^{-1}$ a testemunha mantida em competição com as plantas daninhas produziu em média 2,0 ton.ha ${ }^{-1}$ de milho.

Fica evidente pelos resultados da tabela 3 que as gramíneas forrageiras suprimiram a infestação de plantas daninhas, pois todos os tratamentos comparando as subparcelas com gramíneas forrageiras foram significativamente maiores que a testemunha B (testemunha sem capina). Embora ainda existe um efeito de redução de produtividade significativo entre a testemunha A (capinada) e as subparcelas com 
gramínea forrageira, denotando que ou houve um efeito de interferência competição das plantas daninhas não controladas ou das gramíneas forrageiras ou a somatória dos efeitos combinados de interferências das plantas daninhas e das gramíneas forrageiras.

Os resultados encontrados neste experimento corroboram os resultados verificados por Alvim et al. (1989); Duarte et al. (1995) e Klutchcouski \& Aidar (2003), comprovando assim a viabilidade da consorciação entre estas plantas forrageiras e a cultura do milho. De acordo com Severino (2000), a cobertura vegetal viva de culturas consorciadas que permanece no solo durante toda a estação de crescimento da cultura principal pode ocasionar competição direta por recursos essenciais de crescimento, fato que, possivelmente será a principal forma de supressão das plantas daninhas pela cobertura vegetal.

Um dos fatores que determinam a produtividade de uma cultura agrícola principal em consórcio com outras espécies vegetais é a capacidade competitiva do seu material genético utilizado. Portanto, o cultivar de milho CATI AL 34 utilizado no experimento demonstrou excelentes características de competitividade, pois apesar das reduções de rendimento observadas nos tratamentos com as forrageiras, em relação à testemunha A (capinada), os índices de produtividade da cultura de milho consorciada foram aceitáveis (tabela 3), comprovando a viabilidade deste sistema de produção.

Na tabela 4 pode ser observado que os resultados dos tratamentos com $P$. maximum apresentam maior produção de massa verde, quando comparado com os resultados das demais forrageiras, em todos os tratamentos com plantas daninhas, inclusive na testemunha $\mathrm{C}$ onde não havia infestação de plantas daninhas, seguido do tratamento com B. brizantha e B. decumbens. Dentre os subtratamentos plantas daninhas, verifica-se que a testemunha $\mathrm{C}$ teve uma produção significativamente maior daquelas onde houve incidência das plantas daninhas I. grandifolia e A. hybridus (comparação dentro das colunas da tabela) e semelhante às subparcelas com $D$. horizontalis. No entanto, quanto é analisado dentre cada planta daninha, observa-se que não houve diferença, indicando que o efeito competitivo das diferentes espécies de plantas forrageiras utilizadas no experimento foi semelhante. Ainda na tabela 4, pode-se 
verificar que os resultados das médias de produção de massa verde dos tratamentos onde se utilizou $P$. maximum, $B$. brizantha e $B$. decumbens, foram de 90,11\%, 71,25\% e 87,02\% respectivamente, quando comparados com a média dos resultados das suas respectivas testemunhas. Fica evidente através destes resultados que a $D$. horizontalis é a planta daninha menos competitiva no sistema.

Tabela 3. Rendimento do milho em grãos (ton.ha ${ }^{-1}$ ) na interação de tratamentos com culturas forrageiras e plantas daninhas, aos 150 dias após a instalação do experimento. Piracicaba, ESALQ/USP, maio de 2004

B.
decumbens
$(3)$

I. grandifolia

A. hybridus

D. horizontalis

\section{Plantas daninhas}

C.V.\%

\section{Rendimento da cultura do milho (ton.ha ${ }^{-1}$ )}

$\begin{array}{ccccc}4,04{ }^{(4)} \mathrm{aC} & 4,00 \mathrm{aC} & 5,19 \mathrm{aB} & 7,13 \mathrm{~A} & 1,98 \mathrm{D} \\ 4,10 \mathrm{aC} & 4,08 \mathrm{aC} & 5,17 \mathrm{aB} & 7,01 \mathrm{~A} & 2,35 \mathrm{D} \\ 4,18 \mathrm{aC} & 4,07 \mathrm{aC} & 5,18 \mathrm{aB} & 7,04 \mathrm{~A} & 2,31 \mathrm{D} \\ & & 11,11 & & \end{array}$

(1) Milho solteiro sem interferências das plantas daninhas (capinado); ${ }^{(2)}$ Milho solteiro com interferência da infestação natural de plantas daninhas (sem capina); ${ }^{(3)}$ milho consorciado com as plantas forrageiras; ${ }^{(4)}$ Médias seguidas pela mesma letra na linha (maiúscula) e na coluna (minúscula) não diferem estatisticamente entre si pelo teste de Tukey ao nível de 5\% de probabilidade.

A boa produtividade das plantas forrageiras no sistema pode ser explicada em função da semeadura das plantas forrageiras ter sido realizada no mesmo dia da semeadura da cultura do milho, fato que permitiu às forrageiras maior acúmulo de matéria verde devido, provavelmente, a um menor efeito da competição inter-específica. Tais resultados corroboram com os demonstrados por Shelton \& Humphreys (1972) e Souza Neto (1993).

A maior produtividade e agressividade do $P$. maximum na testemunha $\mathrm{C}$ (capinada), quando comparado com as forrageiras B. decumbens e B. brizantha (tabela 
4) não refletiu em maior competitividade com as plantas daninhas e a cultura do milho. Apesar da descrição agronômica de Alcântara \& Bufarah (1999), de que o P. maximum é uma planta forrageira agressiva e de alta produtividade, esta também sofre os efeitos da competição inter-específica.

Tabela 4. Produção de massa verde das plantas forrageiras (ton.ha ${ }^{-1}$ ) na interação de tratamentos com culturas forrageiras e plantas daninhas, aos 160 dias após a instalação do experimento. Piracicaba, ESALQ/USP, maio de 2004

Plantas daninhas

\section{I. grandifolia}

A. hybridus

D. horizontalis

Testemunha $\mathrm{C}^{(1)}$

C.V.\%

\section{Rendimento das plantas forrrageiras (ton.ha ${ }^{-1}$ - biomassa verde)}

\section{B. decumbens}

$32,96^{(2)} \mathrm{bB}$

33,01 bB

$56,07 \mathrm{aB}$

$37,47 \mathrm{~A}$

\section{B. brizantha}

$32,25 \mathrm{bB}$

$32,56 \mathrm{bB}$

$56,18 \mathrm{aB}$

45,80 A

12,50

(1) Cultura forrageira solteira sem interferência das plantas daninhas (capinada); ${ }^{(2)}$ Médias seguidas pela mesma letra na linha (maiúscula) e na coluna (minúscula) não diferem estatisticamente entre si pelo teste de Tukey ao nível de 5\% de probabilidade.

Na tabela 5, pode-se observar que as três culturas forrageiras testadas em consórcio com milho suprimiram de maneira significativa a densidade de infestação das três plantas daninhas estudadas na experimentação aos 30 dias após a instalação do experimento. Esta supressão é evidenciada quando os valores da infestação de plantas daninhas nas parcelas consorciadas são comparados com os valores das infestações da testemunha onde as plantas daninhas cresceram sem competição inter-específica das culturas.

Em relação à planta daninha capim-colchão, não houve diferença significativa entre os tratamentos em consorciação do milho e forrageiras (tabela 5). Este resultado pode ser explicado pelo fato do capim-colchão também ser uma gramínea, portanto, possui um ciclo biológico semelhante ao das plantas forrageiras, o que diminui a 
possibilidade de quebra do sincronismo do ciclo biológico e ocupação de nichos ecológicos semelhantes.

O melhor resultado na supressão das plantas daninhas foi obtido no tratamento com B. brizantha (tabela 5), fato que comprova a maior eficiência da espécie sobre o controle das plantas daninhas testadas, seguida de $P$. maximum e $B$ decumbens, sendo esta última, a que apresentou a menor eficácia na supressão das plantas daninhas.

A redução efetiva da infestação de plantas daninhas no sistema pode ser atribuída aos efeitos alelopáticos e/ou competitivos, uma vez que essas espécies forrageiras possuem características bastante favoráveis no que diz respeito à obtenção de fatores de produção, de acordo com o mencionado por Chou et al. (1989), Silva (1997), Stanizio et al. (1991) e Dias Filho (2000).

Outro aspecto que deve ser mencionado é que, possivelmente, o fato da semeadura da cultura do milho e das culturas forrageiras terem sido realizadas no mesmo dia, conferiu às plantas forrageiras uma maior capacidade de supressão das plantas daninhas, devido ao fato das plantas forrageiras rapidamente ocuparem seu nicho ecológico e, conseqüentemente, diminuírem os recursos necessários ao crescimento e desenvolvimento das plantas daninhas. Estes resultados estão de acordo com os observados por Radosevich (1996) e Silva et al. (2004).

O sucesso no estabelecimento da cultura do milho consorciada com pastagens é função do manejo adequado de espécies de plantas com exigências fisiológicas semelhantes. Na presente experimentação fica evidente que a consorciação das três espécies forrageiras estudadas com a cultura do milho é adequada. Este fato resulta em redução do nicho ecológico para estabelecimento das plantas daninhas, conforme evidenciado nos resultados da tabela 5.

Na tabela 6, pode-se verificar que as três plantas forrageiras consorciadas com milho suprimiram de maneira significativa a densidade de infestação das três plantas daninhas estudadas no experimento. Com exceção do tratamento com B. decumbens no controle de I. grandifolia, cuja infestação foi semelhante à testemunha D. 
Tabela 5. Infestação de plantas daninhas (plantas.m ${ }^{-2}$ ) na interação de tratamentos com culturas forrageiras e plantas daninhas, aos 30 dias após a instalação do experimento. Piracicaba, ESALQ/USP, maio de 2004

\begin{tabular}{lccc}
\hline \multirow{2}{*}{ Plantas forrageiras } & \multicolumn{3}{c}{ Infestação de plantas daninhas (plantas. ${ }^{-2}$ ) } \\
B. decumbens & I. grandifolia & A. hybridus & D. horizontalis \\
B. brizantha & $28,5^{(2)}$ aA & $16,9 \mathrm{bB}$ & $5,5 \mathrm{bC}$ \\
P. maximum & $2,3 \mathrm{cAB}$ & $6,6 \mathrm{cA}$ & $1,9 \mathrm{bB}$ \\
Testemunha & ${ }^{(\mathbf{1})} \mathbf{D}$ & $2,5 \mathrm{cB}$ & $4,9 \mathrm{bB}$ \\
C.V.\% & $11,2 \mathrm{bA}$ & $71,7 \mathrm{aA}$ & $32,4 \mathrm{aC}$ \\
\hline${ }^{(1)}$ Testemunha D onde as plantas daninhas foram mantidas sem a presença das culturas do milho \\
e forrageiras; ${ }^{(2)}$ Médias seguidas por letras distintas maiúsculas na linha e minúsculas na coluna \\
diferem entre si a 5\% de significância pelo teste de Tukey.
\end{tabular}

Analisando individualmente o efeito da $B$. decumbens sobre as três plantas daninhas, observa-se que a forrageira inibiu de forma mais acentuada a planta daninha $D$. horizontalis, seguido do A. hybridus, sendo que o menor efeito foi causado sobre a planta daninha I. grandifolia (tabela 6). Os resultados de redução da infestação pela $B$. brizantha, no entanto, foram semelhantes para as três plantas daninhas estudadas. Já para o P. maximum, este efeito foi mais pronunciado sobre as plantas daninhas A. hybridus e $D$. horizontalis. Fica evidente na pesquisa que dentre as plantas daninhas estudadas, a $I$. grandifolia é a que apresenta maior competitividade no sistema de integração lavourapecuária.

Willey (1979) destaca o fato de plantas em coexistência em um agroecossistema apresentar fisiologia de crescimento semelhantes condiciona relações competitivas inter-específicas mais intensas. Assim, como pode ser observado na tabela 6, a $D$. horizontalis, que apresenta fisiologia semelhante às plantas forrageiras (mesma família botânica - Poaceae), foi a planta daninha menos competitiva no sistema, e assim, de uma maneira geral foi a que sofreu maior efeito supressivo. 
Ainda, como pode ser observado na tabela 2, o fato de não ter ocorrido déficit hídrico no período da realização do experimento, permite inferir que os resultados encontrados neste ensaio concordam com os observados e mencionados por Dias Filho (2000), de que a forrageira quando estabelecida em consórcio mantém seu crescimento mesmo com o sombreamento ocasionado pelo milho. Este fato, provavelmente, contribui para a supressão da infestação das plantas daninhas devido ao efeito de competição e/ou alelopático, uma vez que essas plantas forrageiras possuem boa plasticidade fenotípica quanto à captura de radiação em resposta ao sombreamento, e como conseqüência, a capacidade de manter o crescimento mesmo com restrição de luz.

Na tabela 7 estão apresentados os parâmetros do modelo logístico de acúmulo de massa seca durante o crescimento das plantas daninhas (massa seca.planta ${ }^{-1}$ ) na presença da cultura do milho, variando os tratamentos com as culturas forrageiras. Estes parâmetros foram então utilizados para elaboração dos gráficos contidos nas figuras 1 a 3. Observa-se pela tabela 7 que todas as equações tiveram bom ajuste matemático pois os valores de $r^{2}$ foram acima de 0,9 . Verifica-se que todos os pontos de mínimo das curvas, representados pelo parâmetro $a$ são positivos e próximo de zero, exceto para a equação que representa a I. grandifolia com valores próximo de 10 e isto reflete o desenvolvimento inicial lento da planta daninha, conforme foi observado no experimento. O tempo necessário para que 50\% da resposta da variável ocorresse (c) para todas as plantas daninhas variou entre 56,9 dias para a I. grandifolia e 79,0 dias para o A. hybridus, indicando que esta última planta daninha apresenta desenvolvimento mais lento, fato este comprovado pelos valores de $d$ que indicam a declividade da curva, onde os valores menos negativos indicam menores declividades da curva, portanto crescimento mais lento.

Na figura 1 pode-se observar que a produção de biomassa seca por planta da planta daninha I. grandifolia foi suprimida de forma semelhante pelas três culturas forrageiras consorciadas com a cultura do milho, principalmente à partir dos 70 dias aproximadamente, quando comparada com a curva de crescimento da planta daninha no 
tratamento sem as culturas. Este fato pode ser explicado pelas características de alta competitividade das culturas forrageiras consorciada com a cultura do milho, sendo que os resultados indicam que a capacidade competitiva das culturas forrageiras estudadas foram semelhantes.

Tabela 6. Infestação de plantas daninhas (plantas.m ${ }^{-2}$ ) na interação de tratamentos com culturas forrageiras e plantas daninhas, aos 60 dias após a instalação do experimento. Piracicaba, ESALQ/USP, maio de 2004

Plantas forrageiras

Infestação de plantas daninhas (plantas. $\mathrm{m}^{-2}$ )

$\begin{array}{lccc} & \text { I. grandifolia } & \text { A. hybridus } & \text { D. horizonta } \\ \text { B. decumbens } & 33,5^{(2)} \mathrm{aA} & 18,8 \mathrm{bB} & 5,6 \mathrm{bC} \\ \text { B. } \text { brizantha } & 3,6 \mathrm{cA} & 4,3 \mathrm{cA} & 3,4 \mathrm{bA} \\ \text { P. } \text { maximum } & 12,4 \mathrm{bA} & 3,6 \mathrm{cB} & 4,3 \mathrm{bB} \\ \text { Testemunha }^{(\mathbf{1})} \mathbf{D} & 36,3 \mathrm{aB} & 72,2 \mathrm{aA} & 37,3 \mathrm{aB}\end{array}$

C.V.\% 13,08

${ }^{(1)}$ Testemunha D onde as plantas daninhas foram mantidas sem a presença das culturas do milho e forrageiras; ${ }^{(2)}$ Médias seguidas por letras distintas maiúsculas na linha e minúsculas na coluna diferem entre si a 5\% de significância pelo teste de Tukey.

Segundo Kissmann (1992 e 1997) a I. grandifolia apresenta um ciclo de vida que termina depois da maturação das culturas e tende a criar problemas na colheita, quando a infestação é significativa. No entanto, como as culturas forrageiras apresentavam um intenso crescimento no final do ciclo da cultura do milho, o crescimento tardio da $I$. grandifolia foi afetado pelas forrageiras, refletindo assim em menor crescimento nas subparcelas consorciadas da cultura do milho e forrageiras (figura 1).

Na Figura 2, verifica-se que a planta daninha $A$. hybridus teve sua produção de matéria seca por planta inibida pelos três tratamentos com as culturas forrageiras, quando comparada com o tratamento da planta daninha crescendo isoladamente, à partir do qüinquagésimo dia até o octogésimo dia aproximadamente. No entanto, observa-se 
pelas curvas de crescimento que houve supressão diferencial da planta daninha pelas culturas forrageiras, sendo que, o P. maximum foi o mais efetivo nesta supressão, seguido da B. decumbens. A B. brizantha proporcionou o menor efeito supressivo, tanto que no final do ciclo da planta daninha o acúmulo de massa seca por planta igualou-se com o acúmulo no tratamento onde a planta daninha cresceu isoladamente.

Tabela 7. Parâmetros do modelo logístico para a variável acúmulo de massa seca por planta (g) durante o crescimento das plantas daninhas na presença da cultura do milho e das diferentes culturas forrageiras utilizadas no experimento e na testemunha

\begin{tabular}{|c|c|c|c|c|c|c|c|}
\hline \multirow{2}{*}{\multicolumn{2}{|c|}{ Tratamentos }} & & \multicolumn{5}{|c|}{ Parâmetros } \\
\hline & & & $\mathbf{a}$ & $\mathbf{b}$ & c & d & $\mathbf{r}^{2}$ \\
\hline \multirow{12}{*}{ Milho } & \multirow{3}{*}{ B. decumbens } & IAQGR & 9,636 & $-9,289$ & 54,453 & 11,143 & 0,997 \\
\hline & & АMАСН & 0,783 & 14,971 & 68,639 & $-7,762$ & 0,980 \\
\hline & & DIGHO & 0,394 & 17,685 & 73,236 & $-8,901$ & 0,998 \\
\hline & \multirow{4}{*}{ B. brizantha } & IAQGR & 0,386 & 9,513 & 56,927 & $-16,936$ & 0,995 \\
\hline & & АМАСН & 1,242 & 18,300 & 79,006 & $-7,903$ & 0,978 \\
\hline & & DIGHO & 0,469 & 17,788 & 74,933 & $-9,493$ & 0,996 \\
\hline & & IAQGR & 0,148 & 9,726 & 54,453 & $-9,203$ & 0,998 \\
\hline & \multirow[t]{3}{*}{ P. maximum } & АМАСН & 0,536 & 12,759 & 61,811 & $-6,171$ & 0,983 \\
\hline & & DIGHO & 0,368 & 18,341 & 73,558 & $-9,164$ & 0,999 \\
\hline & & IAQGR & 0,688 & 20,630 & 71,329 & $-5,934$ & 0,986 \\
\hline & \multirow[t]{2}{*}{ Testemunha $\mathrm{D}^{(1)}$} & АМАСН & 1,115 & 18,500 & 58,025 & $-13,464$ & 0,988 \\
\hline & & DIGHO & 0,207 & 23,023 & 68,538 & $-5,764$ & 0,996 \\
\hline
\end{tabular}

${ }^{(1)}$ Testemunha D = planta daninha crescendo sem a presença da cultura do milho e das culturas forrageiras.

Segundo Dias Filho (2000 e 2002), a B. brizantha apresenta determinada plasticidade fenotípica e tolerância em resposta ao sombreamento, porém reduz sua capacidade fotossintética. Em ambiente sombreado, essa mesma espécie apresenta maior área foliar específica, maior razão de área foliar e menor relação entre clorofila a e b, economizando o nitrogênio necessário à captura de luz, bem como baixo ponto de 
compensação luminoso, promovendo um balanço positivo de carbono para seu crescimento. Assim, a B. brizantha permitiu maior crescimento da planta daninha $A$. hybridus quando comparado com as outras forrageiras (figura 2).

Os resultados da planta daninha $D$. horizontalis (figura 3) foram semelhantes aos da planta daninha I. grandifolia, onde todas as culturas forrageiras tiveram efeito supressivo semelhantes, porém de forma menos intensa. Destaca-se nestes resultados que o inicio da interferência foi mais precoce que as duas outras espécies de plantas daninhas estudadas, ou seja, aproximadamente aos 40 dias após a semeadura da cultura do milho. Provavelmente, esse fato ocorreu em função da planta daninha e das culturas forrageiras pertencerem à mesma família botânica, e consequentemente de mesmo nicho ecológico, indicando um efeito competitivo mais acentuado pelos recursos de crescimento, logo no início do ciclo de vida das plantas.

Os parâmetros do modelo logístico do parâmetro área foliar por planta das plantas daninhas, representados na tabela 8 indicam que houve valores de ponto de mínimo negativo em duas equações, indicando que a estimativa das equações tiveram dados irreais no início da curva. Por outro lado as curvas tiveram um bom ajuste aos dados originais, pois os valores de $\mathrm{r}^{2}$ foram todos superiores a 0,9 . Os valores de $b$ indicam a grande área foliar desenvolvida pelas plantas daninhas, chegando a valores acima de $1000 \mathrm{~cm}^{2}$ por planta para o caso da I. grandifolia na testemunha (tratamento com a planta daninha em crescimento sem a presença das culturas). O valor de $c$, que é o tempo em dias necessário para que ocorra 50\% de resposta da variável foi semelhante para os parâmetros massa seca (tabela 7) e área foliar (tabela 8), com valores variando de 46,8 dias após a semeadura da cultura do milho para a I. grandifolia com P. maximum até 115,1 dias após a semeadura da cultura do milho para a $D$. horizontalis com $P$. maximum.

Na Figura 4, pode-se notar que a consorciação entre a cultura do milho e as três culturas forrageira reduziu o acúmulo de área foliar da planta daninha I. grandifolia, a partir do sexagésimo dia. Quando em comparação com a testemunha D, os três 
tratamentos com gramíneas forrageiras foram semelhantemente eficientes, pois reduziram praticamente pela metade o valor acumulado de área foliar de I. grandifolia.

Tabela 8. Parâmetros do modelo logístico para a variável acúmulo de área foliar por planta $\left(\mathrm{cm}^{2}\right)$ durante o crescimento das plantas daninhas na presença da cultura do milho e das diferentes culturas forrageiras utilizadas no experimento e na testemunha

\begin{tabular}{|c|c|c|c|c|c|c|c|}
\hline \multirow{2}{*}{\multicolumn{2}{|c|}{ Tratamentos }} & & \multicolumn{5}{|c|}{ Parâmetros } \\
\hline & & & $\mathbf{a}$ & b & c & d & $\mathbf{r}^{2}$ \\
\hline \multirow{12}{*}{ Milho } & \multirow{3}{*}{ B. decumbens } & IAQGR & 1,893 & 499,137 & 49,747 & $-3,326$ & 0,991 \\
\hline & & АMACH & $-15,055$ & 539,459 & 74,214 & $-1,466$ & 0,927 \\
\hline & & DIGHO & 28,281 & 401,811 & 73,684 & $-4,703$ & 0,971 \\
\hline & \multirow{4}{*}{ B. brizantha } & IAQGR & 11,461 & 463,734 & 50,023 & $-4,703$ & 0,990 \\
\hline & & AMACH & $-6,007$ & 468,33 & 56,044 & $-2,145$ & 0,984 \\
\hline & & DIGHO & 24,257 & 423,358 & 73,904 & $-3,484$ & 0,948 \\
\hline & & IAQGR & 35,134 & 410,9581 & 46,808 & $-9,323$ & 0,986 \\
\hline & \multirow[t]{3}{*}{ P. maximum } & АМАСН & 7,124 & 458,215 & 93,133 & $-1,162$ & 0,951 \\
\hline & & DIGHO & 9,660 & 609,906 & 115,05 & $-2,319$ & 0,959 \\
\hline & & IAQGR & 17,053 & 1.093 .485 & 74,094 & $-2,675$ & 0,972 \\
\hline & \multirow[t]{2}{*}{ Testemunha D ${ }^{(1)}$} & AMACH & 12,022 & 417,156 & 47,565 & $-5,573$ & 0,983 \\
\hline & & DIGHO & 2,535 & 509,070 & 56,646 & $-2,758$ & 0,995 \\
\hline
\end{tabular}

${ }^{(1)}$ Testemunha $\mathrm{D}=$ planta daninha crescendo sem a presença da cultura do milho e das culturas forrageiras.

Silva et al. (2004), avaliando a evolução do índice de área foliar (IAF) de milho e B. brizantha, em consórcio e monocultivo, notaram rápido crescimento foliar da cultura em comparação à forrageira. A B. brizantha, quando consorciada apresentou menor IAF do que no monocultivo, onde o IAF máximo foi de 5,6 aos 133 dias após a emergência (DAE), enquanto o milho consorciado ou solteiro apresentou IAF máximo de 4,38 aos 83 DAE. Os resultados da figura 4 permitem inferir que o IAF (apesar da figura indicar a área foliar por planta) da somatória da cultura do milho e forrageiras sombreou o solo 


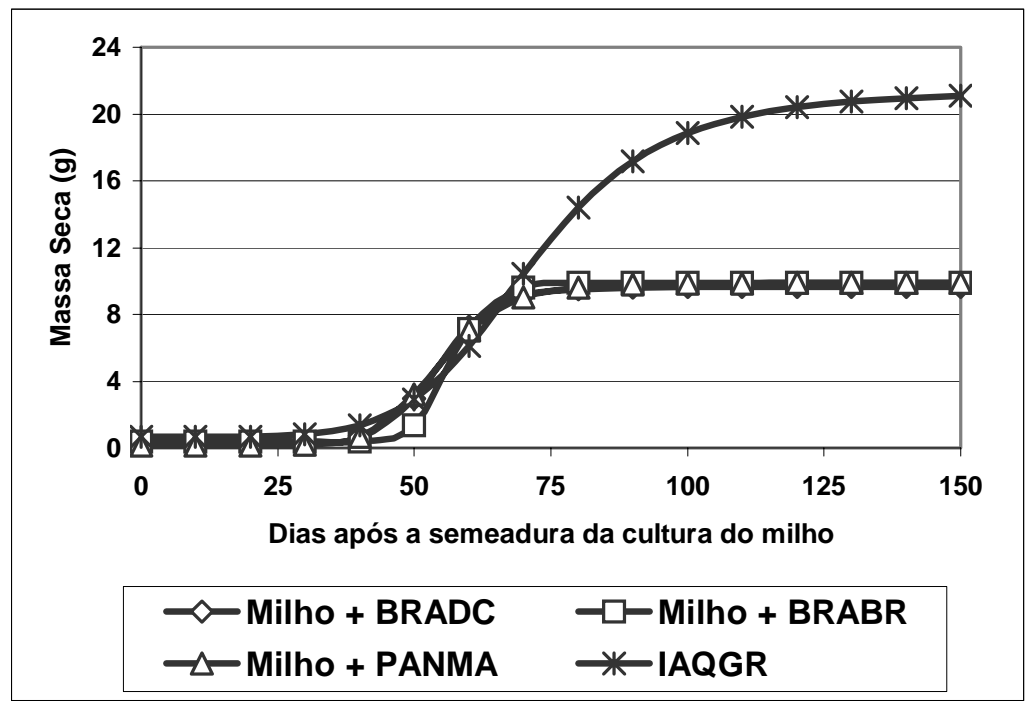

Figura 1 - Acúmulo de massa seca (g) por planta da planta daninha corda-de-viola (Ipomoea grandifolia - IAQGR) quando na presença da cultura do milho e de diferentes culturas forrageiras e IAQGR - sem a presença das culturas (testemunha D)

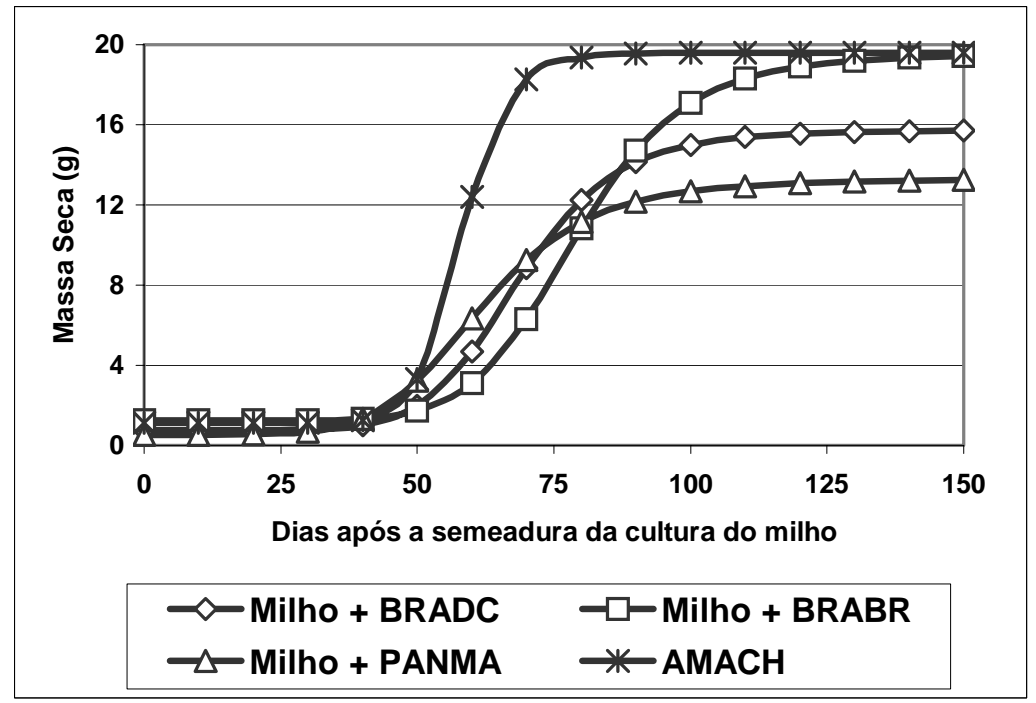

Figura 2 - Acúmulo de massa seca (g) por planta da planta daninha caruru (Amaranthus hybridus - AMACH) quando na presença da cultura do milho e de diferentes culturas forrageiras e AMACH - sem a presença das culturas (testemunha D) 


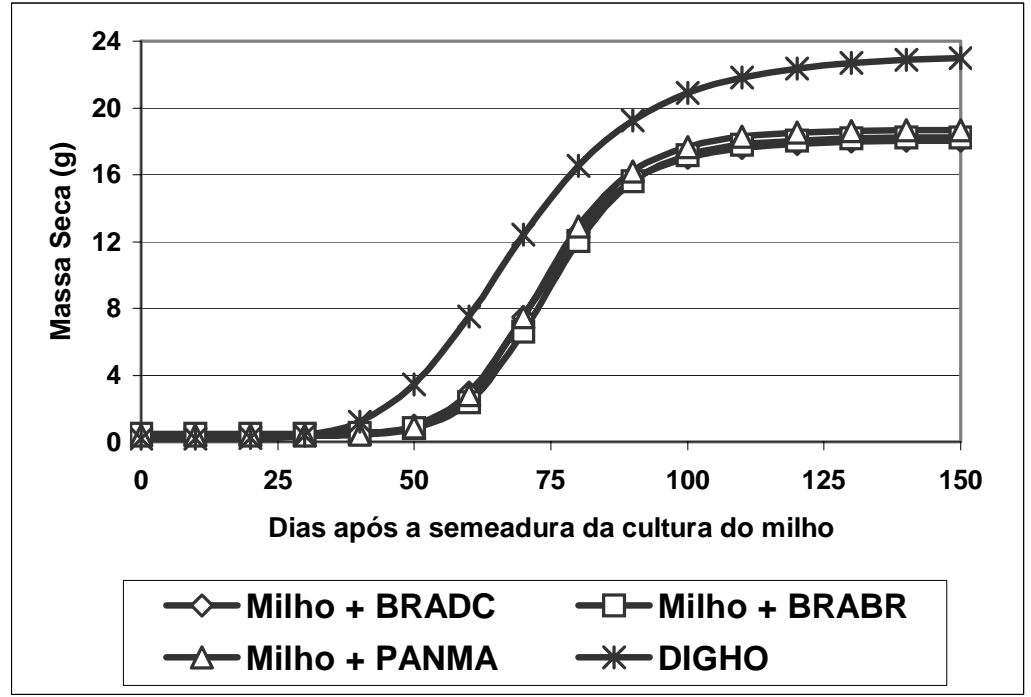

Figura 3 - Acúmulo de massa seca (g) por planta da planta daninha capim-colchão (Digitaria horizontalis - DIGHO) quando na presença da cultura do milho e de diferentes culturas forrageiras e DIGHO - sem a presença das culturas (testemunha D) 
reduzindo, portanto a captura de luz pela planta daninha e como conseqüência houve redução em sua área foliar.

Na Figura 5, pode-se verificar que houve redução do acúmulo de área foliar da planta daninha $A$. hybridus, nos três tratamentos, no entanto, de forma diferenciada, iniciando-se a partir dos 40 dias após a semeadura do milho, indicando que os três tratamentos foram eficientes no período mais crítico de competição durante o ciclo das culturas. Entretanto, o tratamento mais eficiente foi na consorciação da cultura do milho e da cultura forrageira P. maximum, seguido de B. decumbens e B. brizantha, indicando maior competitividade da primeira espécie em relação a essa planta daninha.

Na Figura 6, pode-se verificar que, para a planta daninha $D$. horizontalis, o maior efeito competitivo ocorreu no tratamento onde se realizou o consórcio entre a cultura do milho e a cultura forrageira P. maximum, sendo que, o período de interferência se iniciou por volta do vigésimo quinto dia e foi até aproximadamente o centésimo décimo. No entanto, nesse período os outros dois tratamentos tiveram efeitos semelhantes na redução do acúmulo de área foliar da planta daninha $D$. horizontalis, sendo que no final da experimentação, ou seja, nas colheitas das culturas, os resultados de acúmulo de área foliar da planta daninha $D$. horizontalis, foram semelhantes nos três tratamentos.

Em um sistema de produção consorciado, o balanço de energia proporcionado pela luminosidade no interior do dossel torna-se mais complexo quando comparado ao dossel homogêneo das monoculturas, devido às diferenças entre espécies como altura, arquitetura do dossel, taxa fotossintética e partição de fotoassimilados (Keating \& Carberry et al., 1987). Assim, os resultados obtidos nas figuras 4, 5 e 6 demonstram que as interferências inter-específicas foram varáveis em função da complexidade do balanço energético no sistema.

O parâmetro $a$ (tabela 9) utilizado para a construção das curvas do acúmulo de massa seca (g) por perfilho das culturas forrageiras (figuras 7 a 9) indica que todos os pontos mínimos das curvas são constituídos de valores positivos, mostrando bom 
ajuste das curvas nos pontos iniciais de avaliação, sendo que este bom ajuste também é evidenciado pelos valores de $\mathrm{r}^{2}$ que são todos superiores a 0,9.

Na Figura 7, pode-se verificar que a interferência do efeito somado das três espécies de plantas daninhas mais a cultura do milho foi semelhante sobre a massa seca por perfilho da cultura forrageira $B$. decumbens. Os três tratamentos tiveram efeitos semelhantes na redução do acúmulo de biomassa seca da cultura forrageira $B$. decumbens, sendo que no tratamento testemunha $C$ (B. decumbens sem a presença das plantas daninhas e da cultura do milho) o perfilho de $B$. decumbens acumulou aproximadamente o dobro de massa seca em relação aos demais tratamentos. O efeito da interferência das plantas daninhas e da cultura do milho sobre o acúmulo de massa seca da B. decumbens foi mais pronunciado à partir dos 60 DAS do milho, aproximadamente.

Os resultados do acúmulo de massa seca dos perfilhos da planta forrageira $B$. brizantha (figura 8), indicam que os efeitos competitivos da cultura do milho e plantas daninhas foram pouco pronunciados, quando comparado com a testemunha $\mathrm{C}$ (Brachiaria brizantha crescendo sem a presença de milho e plantas daninhas). Sendo assim, a $B$. brizantha pode ser considerada um cultura forrageira adequada para a integração agricultura-pecuária, devido a sua alta competitividade neste sistema de produção.

Em relação à cultura forrageira $P$. maximum, verifica-se pelos resultados apresentados na figura 9, que esta espécie possui boa competitividade neste sistema de produção, pois os resultados dos três tratamentos, onde havia a cultura do milho e plantas daninhas, tiveram efeitos semelhantes, embora na testemunha C (P. maximum crescendo sem a presença da cultura do milho e das plantas daninhas), o resultado de acúmulo de massa seca (g) por perfilho desta cultura forrageira foi maior do que o resultado dos outros três tratamentos. No entanto, pelos resultados apresentados na figura 9, pode-se inferir que P. maximum, em função de sua eficiência competitiva, pode também ser indicado para este sistema de consorciação. 
Tabela 9. Parâmetros do modelo logístico para a variável acúmulo de massa seca (g) por perfilho das culturas forrageiras na presença da cultura do milho e das diferentes plantas daninhas utilizadas no experimento e sem a presença da cultura de milho e das plantas daninhas (testemunha)

\begin{tabular}{|c|c|c|c|c|c|c|c|}
\hline & & & \multicolumn{5}{|c|}{ Parâmetros } \\
\hline \multicolumn{3}{|c|}{ Tratamentos } & $\mathbf{a}$ & b & c & d & $\mathbf{r}^{2}$ \\
\hline \multirow{3}{*}{\multicolumn{2}{|c|}{ IAQGR }} & B. decumbens & 0,305 & 21,900 & 55,550 & $-13,104$ & 0,998 \\
\hline & & B. brizantha & 2,116 & 60,882 & 81,707 & $-9,586$ & 0,984 \\
\hline & & P. maximum & 1,176 & 58,402 & 84,071 & $-8,552$ & 0,994 \\
\hline \multirow{9}{*}{ Milho } & & B. decumbens & 0,001 & 22,478 & 58,491 & $-7,253$ & 0,997 \\
\hline & АМАСН & B. brizantha & 3,284 & 59,211 & 84,417 & $-17,742$ & 0,987 \\
\hline & & P. maximum & 0,751 & 60,795 & 85,862 & $-8,031$ & 0,990 \\
\hline & & B. decumbens & 0,011 & 22,779 & 56,236 & $-7,746$ & 0,995 \\
\hline & DIGHO & B. brizantha & 2,684 & 60,953 & 83,165 & $-13,889$ & 0,990 \\
\hline & & P. maximum & 1,145 & 60,093 & 84,451 & $-10,275$ & 0,996 \\
\hline & & B. decumbens & 0,162 & 47,076 & 69,657 & $-5,765$ & 0,989 \\
\hline & Testemunha $C^{1}$ & B. brizantha & 1,807 & 65,163 & 79,680 & $-9,585$ & 0,995 \\
\hline & & P. maximum & 1,474 & 64,727 & 79,578 & $-10,491$ & 0,995 \\
\hline
\end{tabular}

Segundo Wutke (1993 e 1998), a recomendação da cobertura vegetal verde consorciada nos agroecossistemas está relacionada ao sistema de produção vigente. Os resultados de produção de biomassa seca das plantas forrageiras obtidos nesta pesquisa demonstram claramente a viabilidade do sistema de produção estudado. Entretanto, é importante considerar no estabelecimento do sistema de produção as características próprias de cada espécie tais como adaptação edafoclimática, porte da planta, época de semeadura, produção final principal, e ainda, práticas culturais e fertilidade do solo que afetam sobremaneira a quantidade de fitomassa produzida e, consequentemente, seu efeito. 


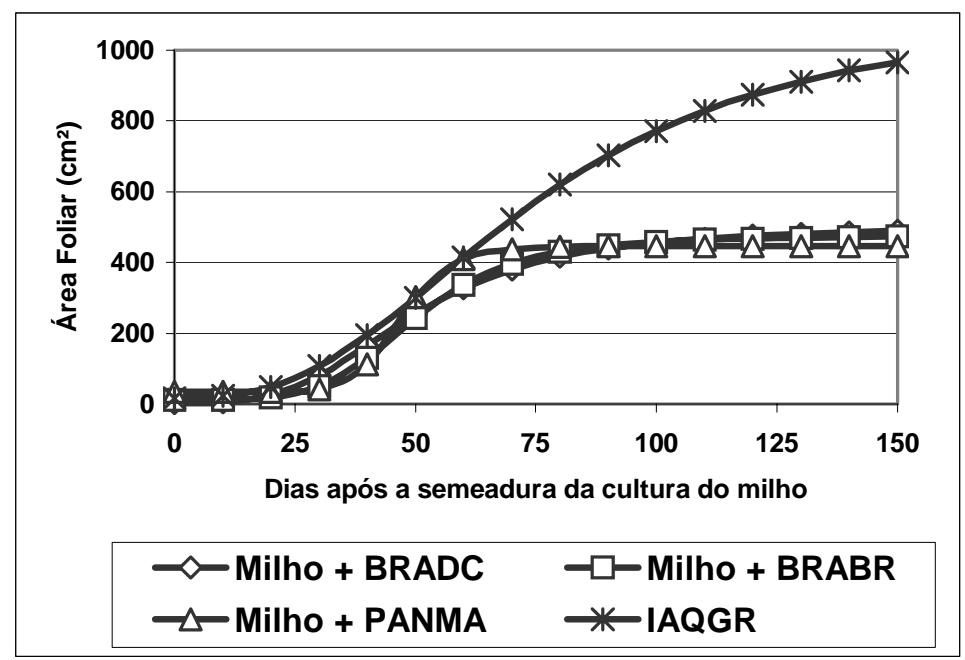

Figura 4 - Acúmulo de área foliar $\left(\mathrm{cm}^{2}\right)$ por planta da planta daninha corda-de-viola (Ipomoea grandifolia - IAQGR) quando na presença da cultura do milho e de diferentes culturas forrageiras e IAQGR - sem a presença das culturas (testemunha D)

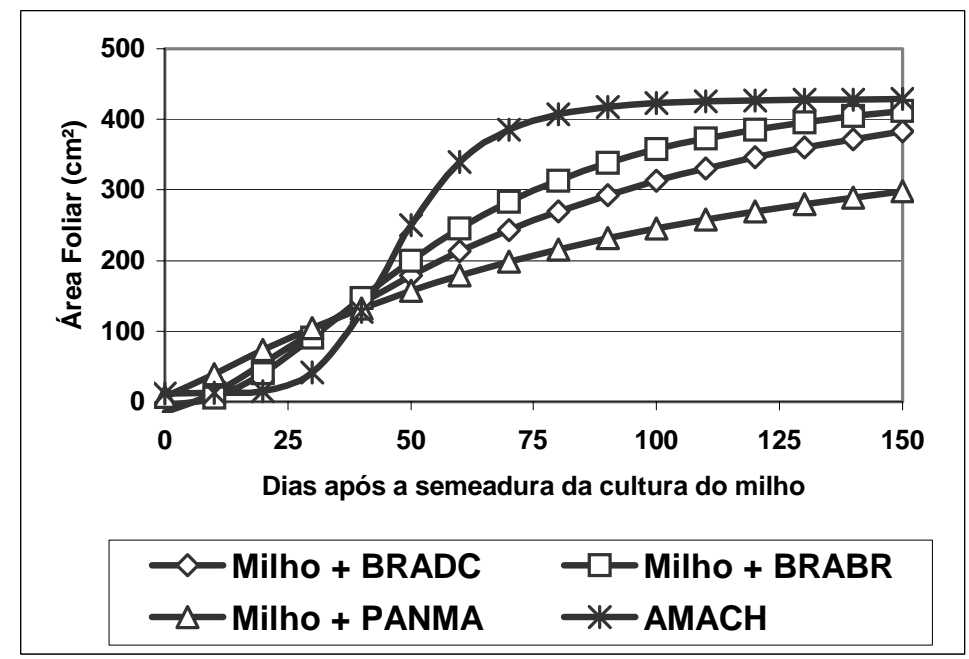

Figura 5 - Acúmulo de área foliar $\left(\mathrm{cm}^{2}\right)$ por planta da planta daninha caruru (Amaranthus hybridus - AMACH) quando na presença da cultura do milho e de diferentes culturas forrageiras e AMACH - sem a presença das culturas (testemunha D) 


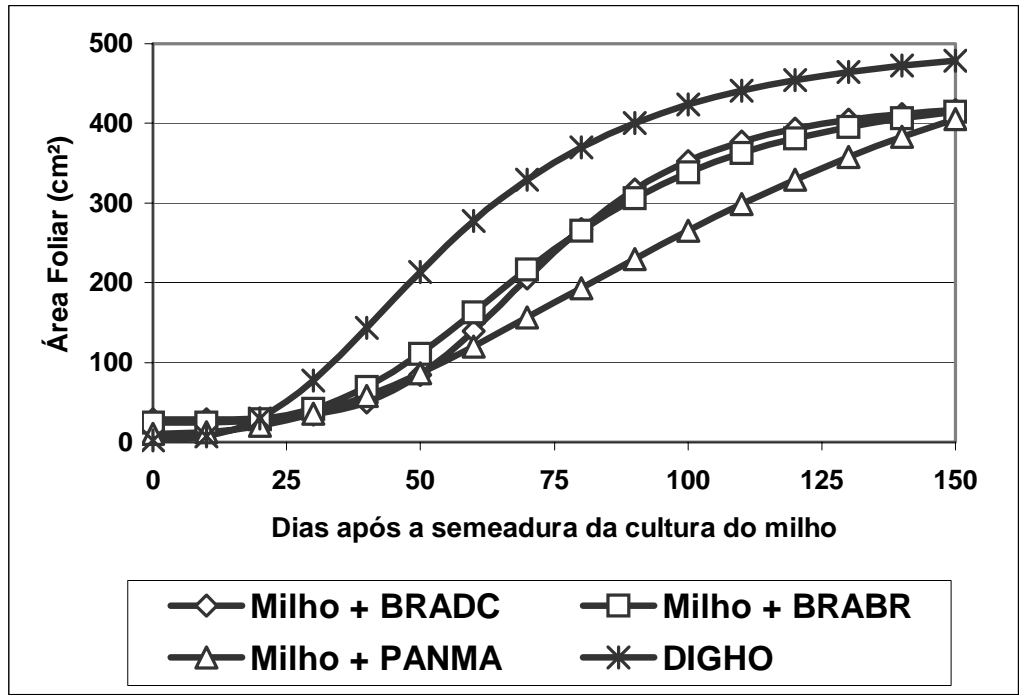

Figura 6 - Acúmulo de área foliar $\left(\mathrm{cm}^{2}\right)$ por planta da planta daninha capim-colchão (Digitaria horizontalis - DIGHO) quando na presença da cultura do milho e de diferentes culturas forrageiras e DIGHO - sem a presença das culturas (testemunha D) 
Os parâmetros das curvas de crescimento de acúmulo de área foliar em $\mathrm{cm}^{2}$ por perfilho com o tempo, em DAE do milho, das culturas forrageiras estão apresentados na tabela 10. As equações geradas representaram adequadamente os dados, devido ao $\mathrm{r}^{2}$ em valores acima de 0,9, bem como os demais parâmetros estão dentro da normalidade de equações que representam adequadamente os dados.

Tabela 10. Parâmetros do modelo logístico para a variável acúmulo de área foliar $\left(\mathrm{cm}^{2}\right)$ por perfilho das culturas forrageiras na presença da cultura do milho e das diferentes plantas daninhas utilizadas no experimento e sem a presença da cultura de milho e das plantas daninhas (testemunha)

\begin{tabular}{|c|c|c|c|c|c|c|c|}
\hline \multirow{2}{*}{\multicolumn{2}{|c|}{ Tratamentos }} & & \multicolumn{5}{|c|}{ Parâmetros } \\
\hline & & & $\mathbf{a}$ & $\mathbf{b}$ & c & d & $\mathbf{r}^{2}$ \\
\hline \multirow{12}{*}{ Milho } & \multirow{3}{*}{ IAQGR } & B. decumbens & 18,018 & 772,467 & 53,225 & $-8,125$ & 0,995 \\
\hline & & B. brizantha & 156,701 & 1371,258 & 82,297 & $-12,545$ & 0,960 \\
\hline & & P. maximum & 144,693 & 1883,264 & 83,902 & $-11,790$ & 0,974 \\
\hline & \multirow{3}{*}{ AMACH } & B. decumbens & 764,064 & $-718,065$ & 55,990 & 69,708 & 0,982 \\
\hline & & B. brizantha & 175,080 & 1421,669 & 83,842 & $-12,868$ & 0,948 \\
\hline & & P. maximum & 115,234 & 1951,255 & 81,102 & $-8,329$ & 0,968 \\
\hline & \multirow{3}{*}{ DIGHO } & B. decumbens & $-5,725$ & 886,251 & 62,801 & $-3,380$ & 0,966 \\
\hline & & B. brizantha & 120,497 & 1512,167 & 80,959 & $-8,649$ & 0,971 \\
\hline & & P. maximum & 188,772 & 1835,583 & 85,829 & $-21,293$ & 0,969 \\
\hline & \multirow{3}{*}{ Testemunha $\mathrm{C}^{1}$} & B. decumbens & 21,233 & 1744,840 & 79,357 & $-3,822$ & 0,965 \\
\hline & & B. brizantha & 137,451 & 1777,040 & 80,476 & $-10,926$ & 0,974 \\
\hline & & P. maximum & 25,912 & 2267,099 & 61,423 & $-2,916$ & 0,955 \\
\hline
\end{tabular}

(1) Testemunha $\mathrm{C}$ = plantas forrageiras solteiras, ou seja, sem a presença da cultura do milho e das plantas daninhas.

Observando-se os resultados apresentados na figura 10, pode-se notar que a interferência dos tratamentos com as três espécies de plantas daninhas mais a cultura do milho foi semelhante sobre a capacidade de acúmulo de área foliar $\left(\mathrm{cm}^{2}\right)$ da cultura forrageira $B$. decumbens, sendo que, no período compreendido entre o sexagésimo dia ao centésimo dia, o resultado do efeito competitivo se pronunciou no tratamento onde havia a cultura do milho e a planta daninha $D$. horizontalis. No tratamento testemunha $C$ ( $B$. 
decumbens sem a presença das plantas daninhas e da cultura do milho) a B. decumbens acumulou aproximadamente o dobro da quantidade de área foliar $\left(\mathrm{cm}^{2}\right)$ comparativamente aos resultados dos demais tratamentos, indicando a menor competitividade dessa espécie forrageira neste sistema de produção.

Os resultados de acúmulo de área foliar $\left(\mathrm{cm}^{2}\right)$ do perfilho da planta forrageira $B$. brizantha (figura 11), indicam que os efeitos competitivos da cultura do milho e plantas daninhas foram pouco acentuados, quando comparado com a testemunha C (B. brizantha crescendo sem a presença de milho e plantas daninhas). Este fato demonstra que a espécie $B$. brizantha possui boas características competitivas e pode ser considerada uma cultura forrageira adequada para o sistema de integração lavoura-pecuária.

Na figura 12, os resultados de acúmulo de área foliar $\left(\mathrm{cm}^{2}\right)$ da planta forrageira P. maximum, demonstram acentuado efeito competitivo pela somatória das presenças das plantas daninhas e da cultura do milho, especialmente a partir dos 30 dias até aproximadamente o centésimo dia, indicando que ocorreu forte competição interespecífica neste período.

Entretanto, os resultados de acúmulo de área foliar $\left(\mathrm{cm}^{2}\right)$ nas avaliações finais foram semelhantes em todos os tratamentos. Sendo assim, verifica-se boa capacidade competitiva dessa espécie forrageira no sistema, indicando que a utilização de $P$. maximum pode ser considerada viável para este sistema de produção. Estes resultados podem indicar que a presença do milho e das plantas daninhas promoveu um retardamento no ciclo de vida da planta forrageira, pois apesar da competição interespecífica acentuada no início do ciclo, o acúmulo final de área foliar foi semelhante.

O sistema de produção que integra lavoura-pecuária, segundo Cobucci (2001), pode trazer benefícios como a reciclagem de nutrientes, controle de erosão, melhoria das propriedades físicas, químicas e biológicas do solo, dentre outras, e ainda propicia alimentação para o gado após a colheita da cultura. No entanto, é importante considerar que esta integração não traga prejuízos significativos para o crescimento da cultura principal, ou seja, a cultura do milho. A experimentação aqui descrita demonstra claramente que a supressão da infestação de plantas daninhas e o retardamento do ciclo 


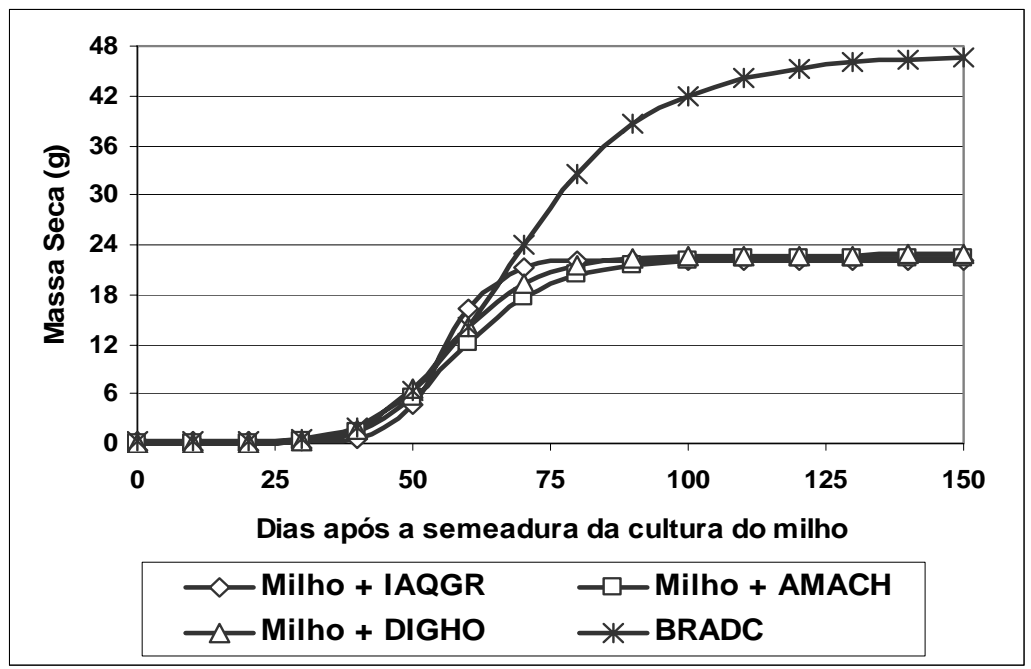

Figura 7 - Acúmulo de massa seca (g) por perfilho da planta forrageira B. decumbens quando na presença da cultura do milho e de diferentes plantas daninhas e BRADC - sem a presença da cultura do milho e das plantas daninhas (testemunha C)

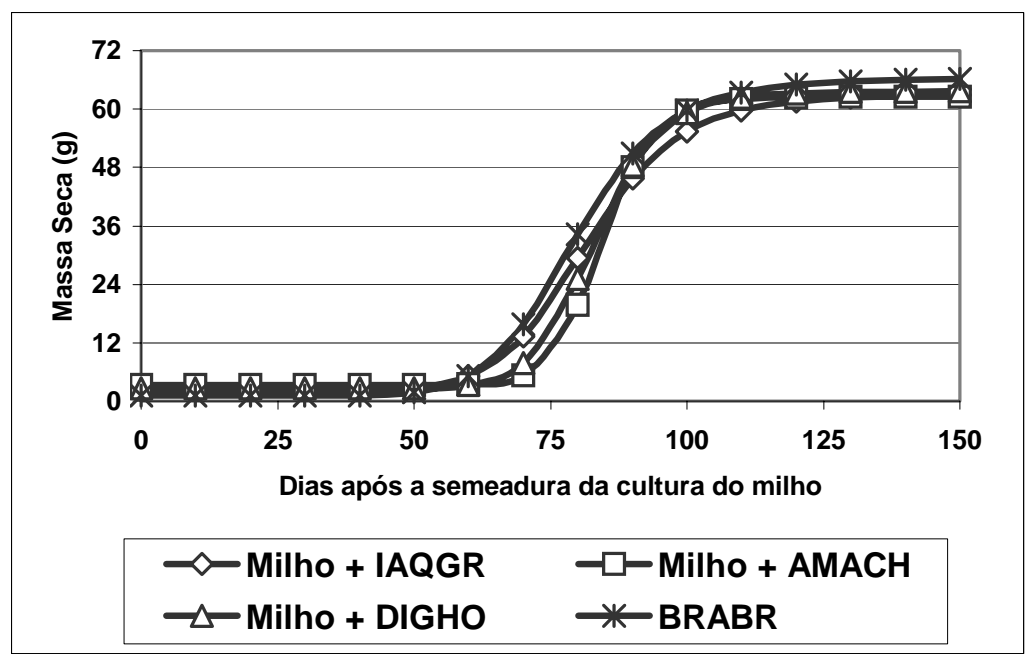

Figura 8 - Acúmulo de massa seca (g) por perfilho da planta forrageira B. brizantha quando na presença da cultura do milho e de diferentes plantas daninhas e BRABR - sem a presença da cultura do milho e das plantas daninhas (testemunha C) 


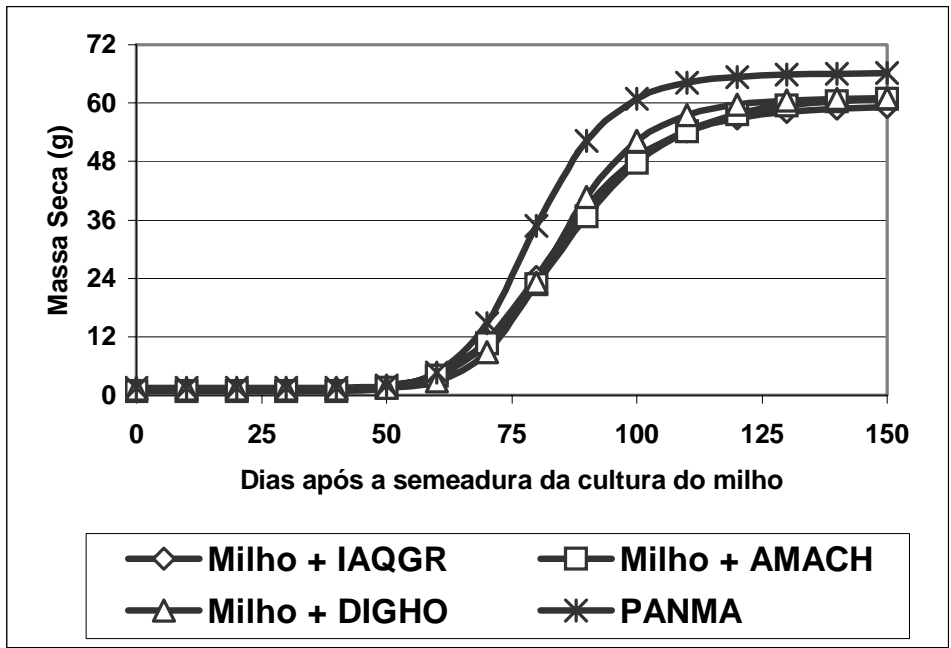

Figura 9 - Acúmulo de massa seca (g) por perfilho da planta forrageira P. maximum quando na presença da cultura do milho e de diferentes plantas daninhas e PANMA - sem a presença da cultura do milho e das plantas daninhas (testemunha C) 
fenológico das plantas forrageiras (figuras 10, 11 e 12) permitem que a cultura do milho (cultura principal) tenha condições de crescimento adequadas durante as fases críticas de crescimento e desenvolvimento das culturas.

Bom ajuste também foi observado para os resultados de acúmulo de massa seca de uma planta de milho, conforme pode ser observado na tabela 11 . Os valores de $a$ são todos positivos, também evidenciando o bom ajuste das curvas.

Analisando-se os resultados de acúmulo de massa seca (g) por planta da cultura do milho na figura 13, nota-se que, nos três tratamentos onde havia culturas forrageiras e a planta daninha I. grandifolia, houve redução do acúmulo de massa seca da planta de milho, sendo esse efeito mais acentuado no tratamento onde se utilizou a cultura forrageira $B$. decumbens, indicando menor competitividade dessa espécie forrageira. Nos resultados dos tratamentos onde foram utilizadas as culturas forrageiras $B$. brizantha e $P$. maximum o efeito competitivo foi menos evidenciado, indicando ser essas espécies competidoras mais eficientes. Entretanto, é notória a diferença entre os resultados dos tratamentos testemunhas quando comparados entre si e quando comparados com os demais tratamentos.

Os resultados de acúmulo de massa seca (g) por planta da cultura do milho apresentados na figura 14, foram semelhantes aos verificados na figura 13, indicando que as interferências causadas pelas espécies de plantas daninhas I. grandifolia e A. hybridus, neste caso, podem ter sido também semelhantes. No entanto, na comparação dos resultados dos tratamentos testemunhas (cultura do milho crescendo na presença da planta daninha A. hybridus - AMACH - e cultura do milho crescendo no limpo testemunha B), pode-se verificar o efeito da competição causado pela planta daninha $A$. hybridus sobre a redução de acúmulo de massa seca (g) por planta da cultura do milho.

Nos resultados da figura 15, observa-se que os três tratamentos em consorciação, reduziram a produção de massa seca (g) da planta da cultura do milho, quando comparados com o resultado do tratamento testemunha A (milho solteiro e capinado), indicando um efeito de competição. Entretanto a redução de acúmulo de massa seca da 
planta de milho foi ainda mais reduzida no tratamento onde a cultura do milho cresceu na presença exclusiva da planta daninha $D$. horizontalis. De maneira geral, observa-se que nos resultados dos três tratamentos houve redução semelhante no acúmulo de massa seca pela planta da cultura do milho.

Tabela 11. Parâmetros do modelo logístico para a variável acúmulo de massa seca (g) por planta da cultura de milho quando na presença de diferentes culturas forrageiras e plantas daninhas, com a presença somente das plantas daninhas e milho solteiro (testemunhas)

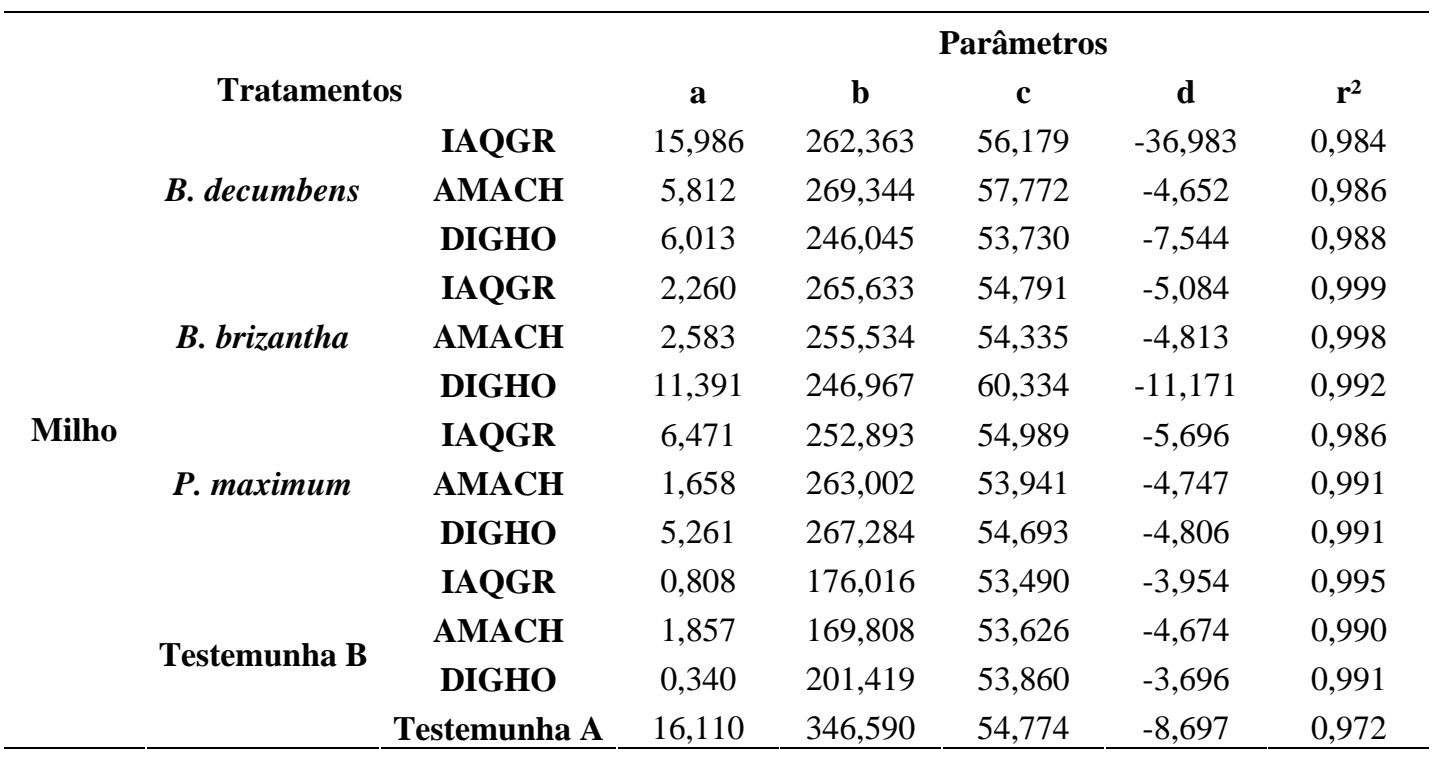

Testemunha $\mathrm{A}$ = milho solteiro sem interferência das plantas daninhas (capinado).

Testemunha $\mathrm{B}=$ milho solteiro com interferências da infestação natural das plantas daninhas.

Analisando-se os resultados de acúmulo de massa seca (g) da planta da cultura do milho crescendo na presença de $B$. decumbens e plantas daninhas (figura 16), pode-se notar que ocorreram reduções semelhantes de acúmulo de massa seca (g) da planta da cultura do milho em todos os tratamentos onde se utilizou as espécies daninhas, 


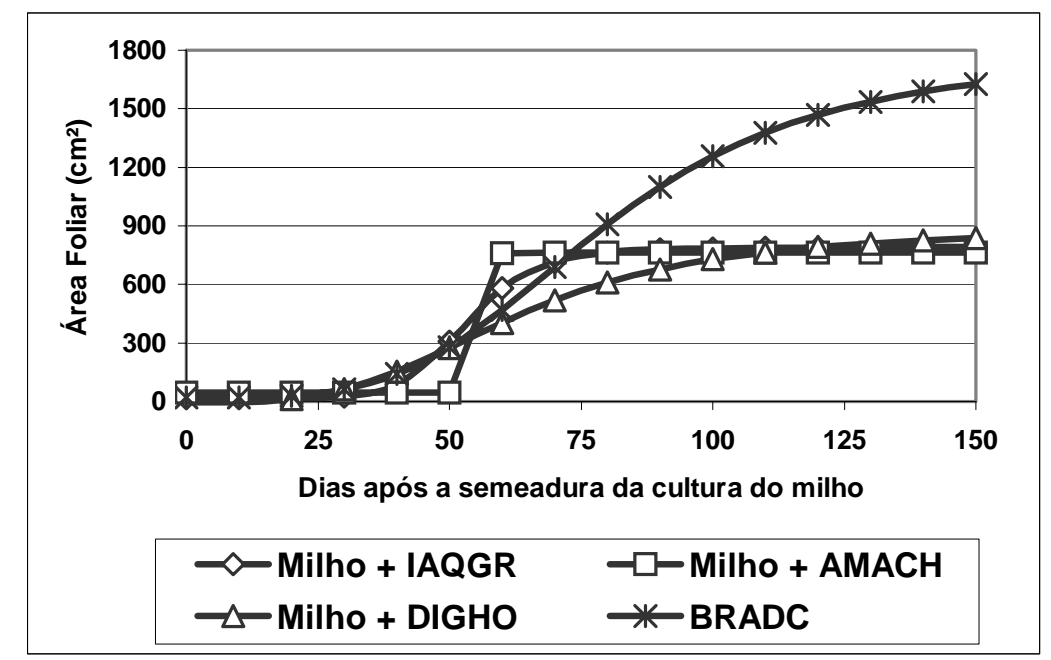

Figura 10 - Acúmulo de área foliar $\left(\mathrm{cm}^{2}\right)$ por perfilho da planta forrageira B. decumbens quando na presença da cultura do milho e de diferentes plantas daninhas e BRADC - sem a presença da cultura do milho e das plantas daninhas (testemunha C)

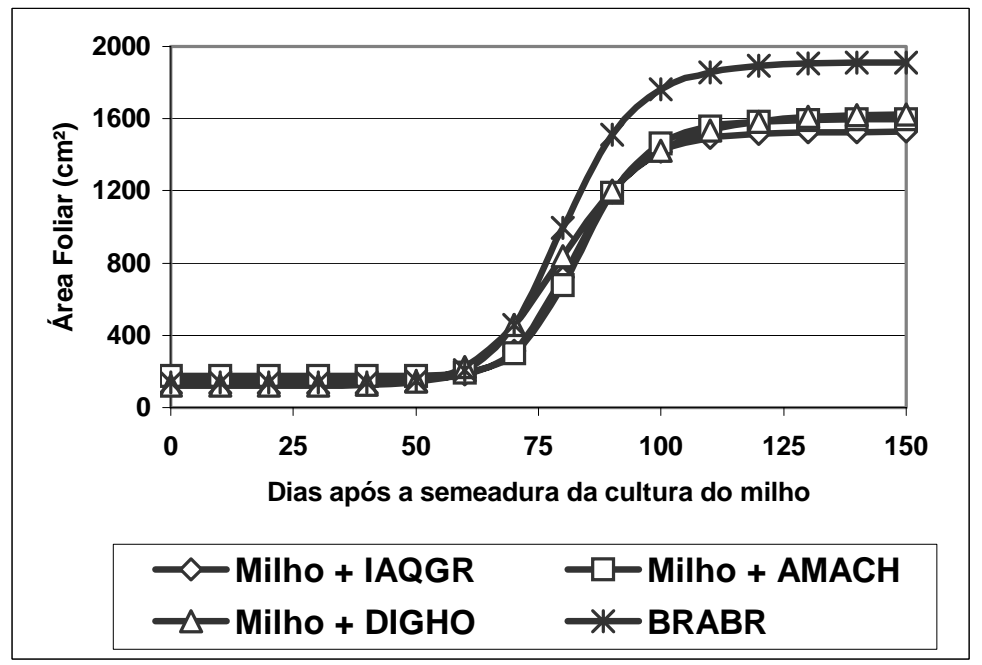

Figura 11 - Acúmulo de área foliar $\left(\mathrm{cm}^{2}\right)$ por perfilho da planta forrageira B. brizantha quando na presença da cultura do milho e de diferentes plantas daninhas e BRABR - sem a presença da cultura do milho e das plantas daninhas (testemunha C) 


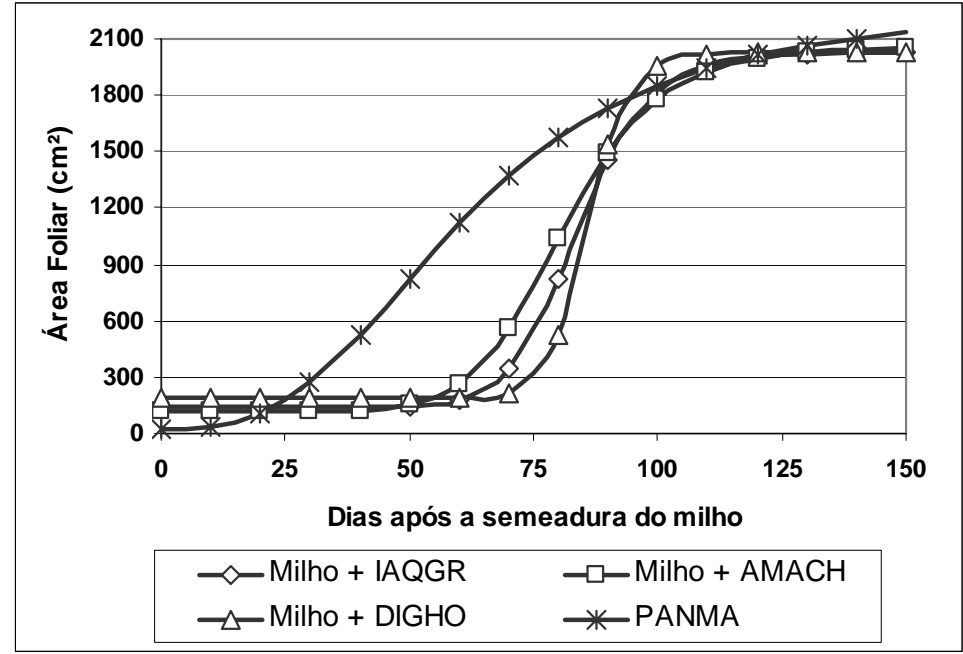

Figura 12 - Acúmulo de área foliar $\left(\mathrm{cm}^{2}\right)$ por perfilho da planta forrageira P. maximum quando na presença da cultura do milho e de diferentes plantas daninhas e PANMA - sem a presença da cultura do milho e das plantas daninhas (testemunha C) 
indicando que ocorreram disputas pelos recursos essenciais de crescimento, notadamente a partir dos 40 dias, prolongando-se este período até aproximadamente aos 100 dias.

Os resultados da figura 17, de acúmulo de massa seca (g) da planta da cultura do milho crescendo na presença de $B$. brizantha, indicam que esta espécie de cultura forrageira consorciada com a cultura de milho, tem boa capacidade de supressão sobre a infestação das três espécies de plantas daninhas testadas, embora possa se verificar no resultado da testemunha A (milho solteiro e capinado) a produção de massa seca (g) pela planta da cultura do milho foi mais elevada do que nos outros tratamentos.

Em relação ao acúmulo de massa seca (g) da planta da cultura do milho crescendo na presença de $P$. maximum (figura 18), os resultados dos tratamentos indicam a boa competitividade desta espécie forrageira na supressão da infestação das três espécies de plantas daninhas estudadas, demonstrando interações competitivas semelhantes para as três plantas daninhas. Assim sendo, pode-se considerar que $P$. maximum, pode fazer parte do sistema de consorciação que integre agricultura-pecuária.

Analisando-se os resultados da figura 19, notam-se os efeitos das interferências negativas causadas pelas três espécies de plantas daninhas testadas, na redução do acúmulo de massa seca (g) da planta da cultura do milho, sendo notório o resultado das interações competitivas exercidas pelas três espécies de plantas daninhas sobre a redução do acúmulo de massa seca (g) da planta da cultura do milho. Comparativamente com o resultado do tratamento padrão (milho solteiro e capinado), os resultados dos demais tratamentos mostram redução pela metade da produção de massa seca (g) da planta da cultura do milho.

Os parâmetros do modelo logístico do parâmetro área foliar por planta das plantas da cultura de milho, representados na tabela 12 indicam que ocorreu bom ajuste dos dados originais das curvas de crescimento da planta da cultura do milho, uma vez que todos os valores de $\mathrm{r}^{2}$ foram superiores a 0,9 . Os valores de $b$ indicam bom desenvolvimento da área foliar pelas plantas da cultura do milho, chegando a valores 


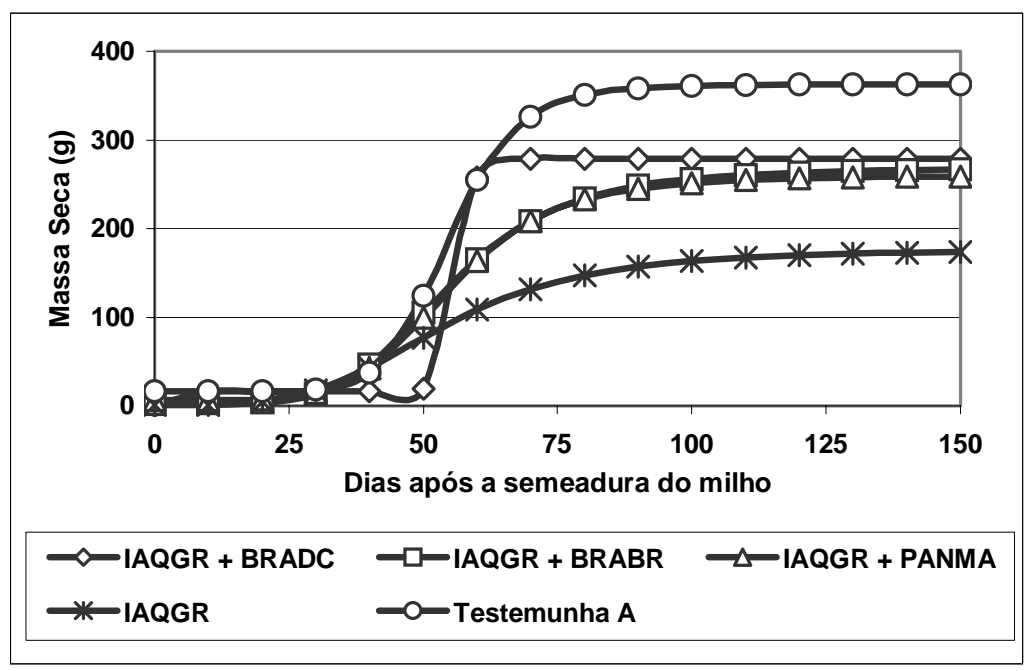

Figura 13 - Acúmulo de massa seca (g) por planta da cultura do milho quando na presença da planta daninha I. grandifolia e de diferentes culturas forrageiras e IAQGR - com a presença somente da planta daninha e testemunha A do milho solteiro e capinado

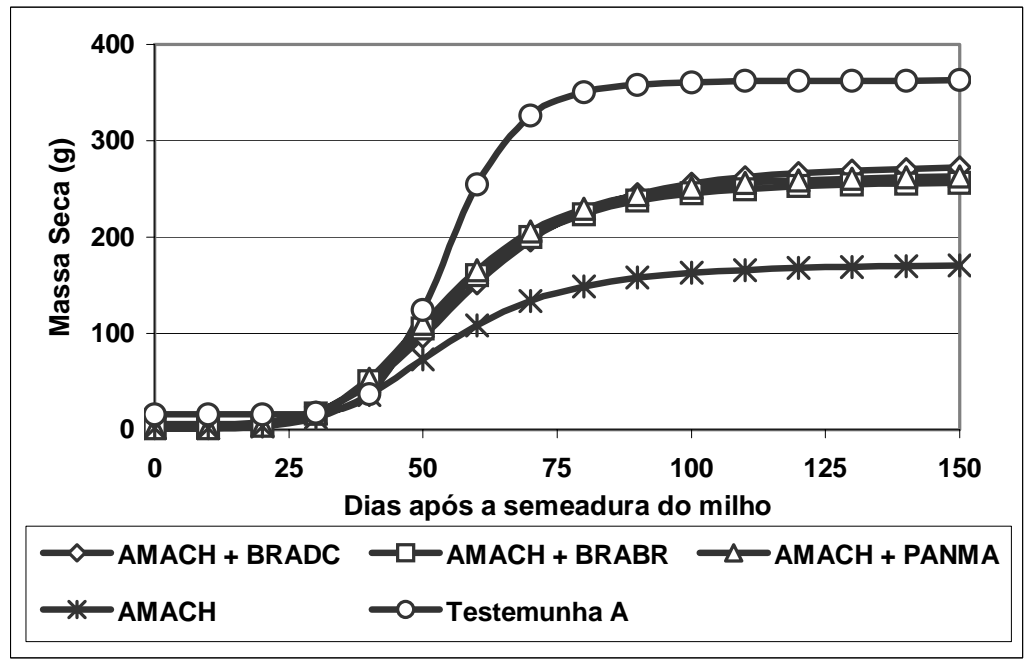

Figura 14 - Acúmulo de massa seca (g) por planta da cultura do milho quando na presença da planta daninha $A$. hybridus e de diferentes culturas forrageiras e AMACH - com a presença somente da planta daninha e testemunha A do milho solteiro e capinado 


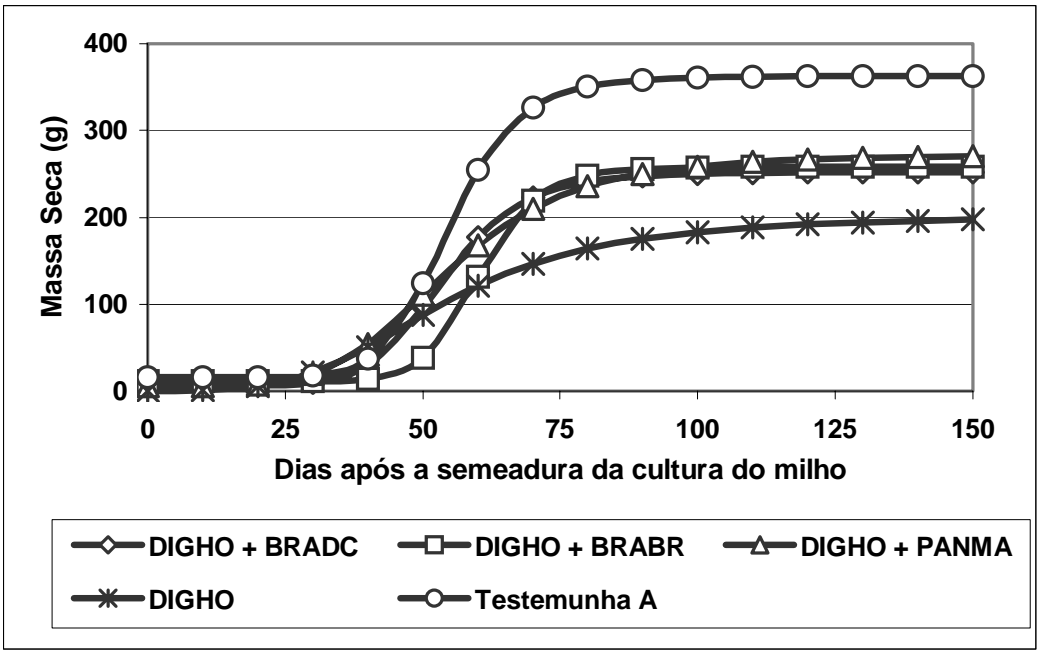

Figura 15 - Acúmulo de massa seca (g) por planta da cultura do milho quando na presença da planta daninha $D$. horizontalis e de diferentes culturas forrageiras e DIGHO- com a presença somente da planta daninha e testemunha A do milho solteiro e capinado 
Na figura 20, os resultados de acúmulo de área foliar $\left(\mathrm{cm}^{2}\right)$ da planta da cultura do milho, indicam efeitos semelhantes para as três culturas forrageiras e a cultura do milho na supressão da planta daninha I. grandifolia. Nota-se também que o maior período competitivo foi do vigésimo quinto dia ao septuagésimo quinto dia, aproximadamente. Entretanto, comparativamente, os resultados dos tratamentos testemunhas (testemunha A e milho crescendo na presença de I. grandifolia- IAQGR) tiveram efeitos diferenciados no acúmulo de área foliar $\left(\mathrm{cm}^{2}\right)$ da planta da cultura do milho entre eles, bem como em relação aos resultados dos demais tratamentos. Ao nível de campo, estes resultados evidenciam a supressão da infestação desta espécie de planta daninha ocasionado pelo efeito somatório das interferências das culturas do milho e forrageiras sobre essa espécie de planta daninha.

Os resultados da figura 21, de acúmulo de área foliar $\left(\mathrm{cm}^{2}\right)$ da planta da cultura do milho, o efeito somatório da competição das três espécies forrageiras testadas consorciadas com a cultura do milho, tiveram efeito semelhante na supressão da planta daninha A. hybridus, propiciando menor redução no acúmulo de área foliar $\left(\mathrm{cm}^{2}\right)$ da planta da cultura do milho, comparativamente com a testemunha (cultura do milho crescendo na presença de $A$. hybridus).

Observando-se os resultados da figura 22, de acúmulo de área foliar $\left(\mathrm{cm}^{2}\right)$ pela cultura do milho quando na presença da planta daninha $D$. horizontalis e de diferentes culturas forrageiras, nota-se que a espécie $D$. horizontalis é a espécie de planta daninha mais competitiva entre as três plantas daninhas testadas. No entanto, no período compreendido entre o vigésimo quinto dia até o octogésimo dia, observa-se acentuada redução do efeito da interferência dessa planta daninha pelo sistema de consorciação entre a cultura do milho e as culturas forrageiras. 


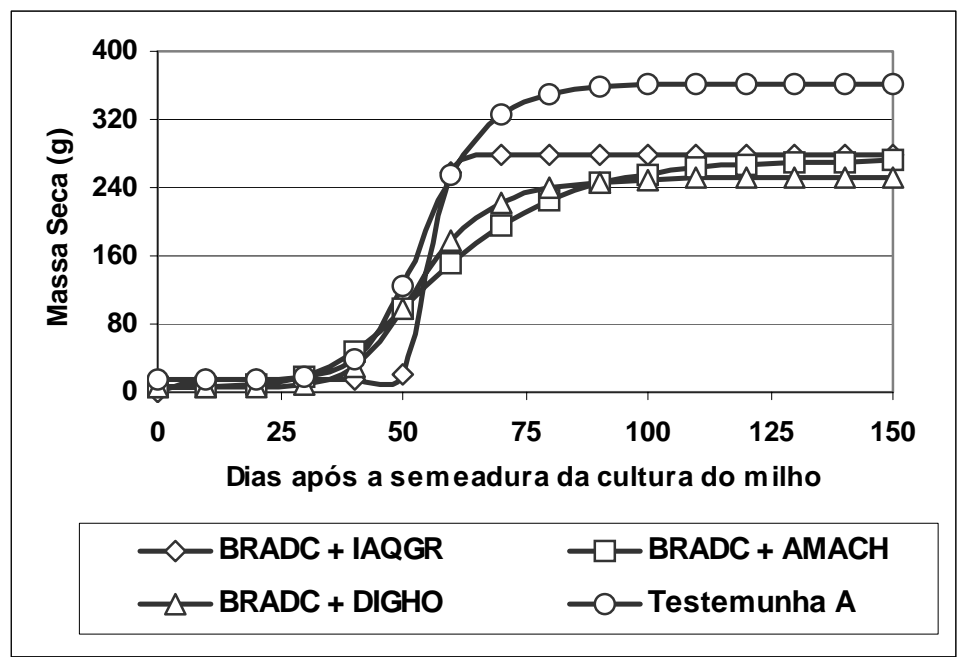

Figura 16 - Acúmulo de massa seca (g) por planta da cultura do milho quando na presença da planta forrageira $B$. decumbens e de diferentes plantas daninhas e sem a presença das culturas forrageiras e das plantas daninhas (testemunha A)

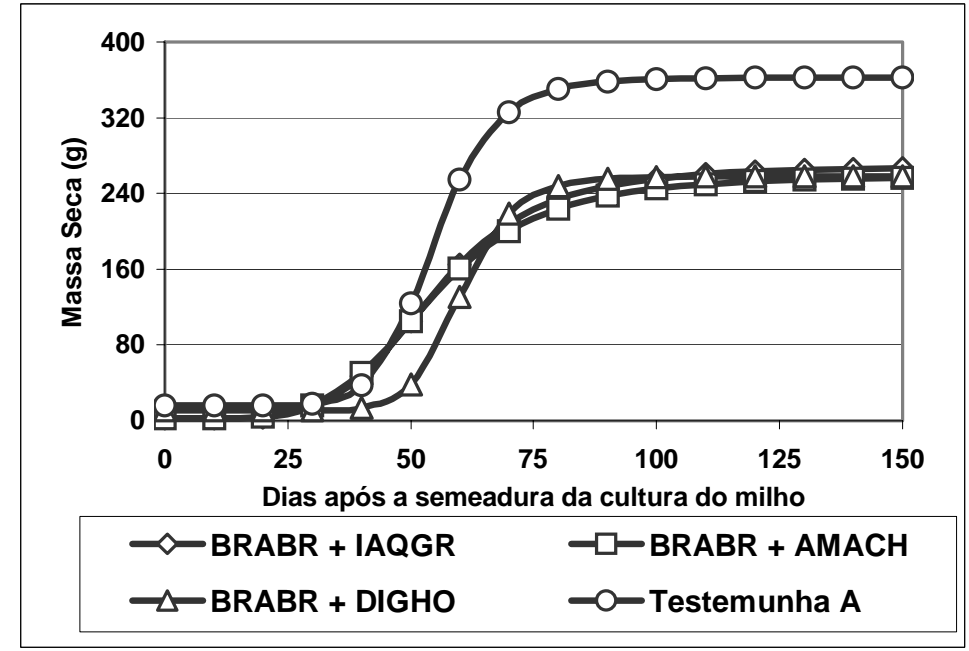

Figura 17 - Acúmulo de massa seca (g) por planta da cultura do milho quando na presença da planta forrageira $B$. brizantha e de diferentes plantas daninhas e sem a presença das culturas forrageiras e das plantas daninhas (testemunha A) 


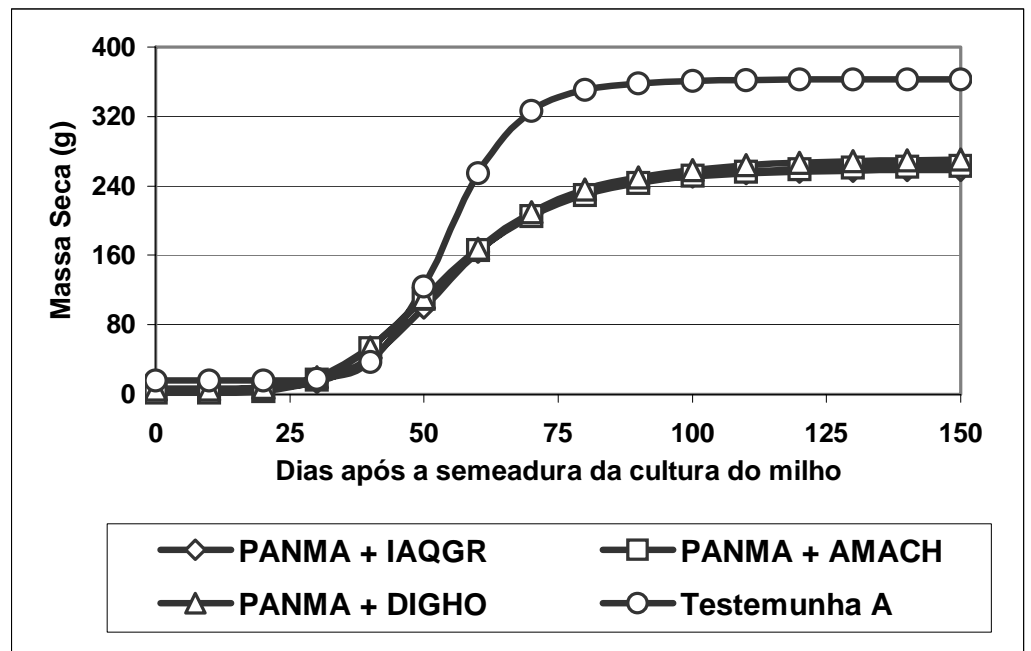

Figura 18 - Acúmulo de massa seca (g) por planta da cultura do milho quando na presença da planta forrageira $P$. maximum e de diferentes plantas daninhas e sem a presença das culturas forrageiras e das plantas daninhas (testemunha A)

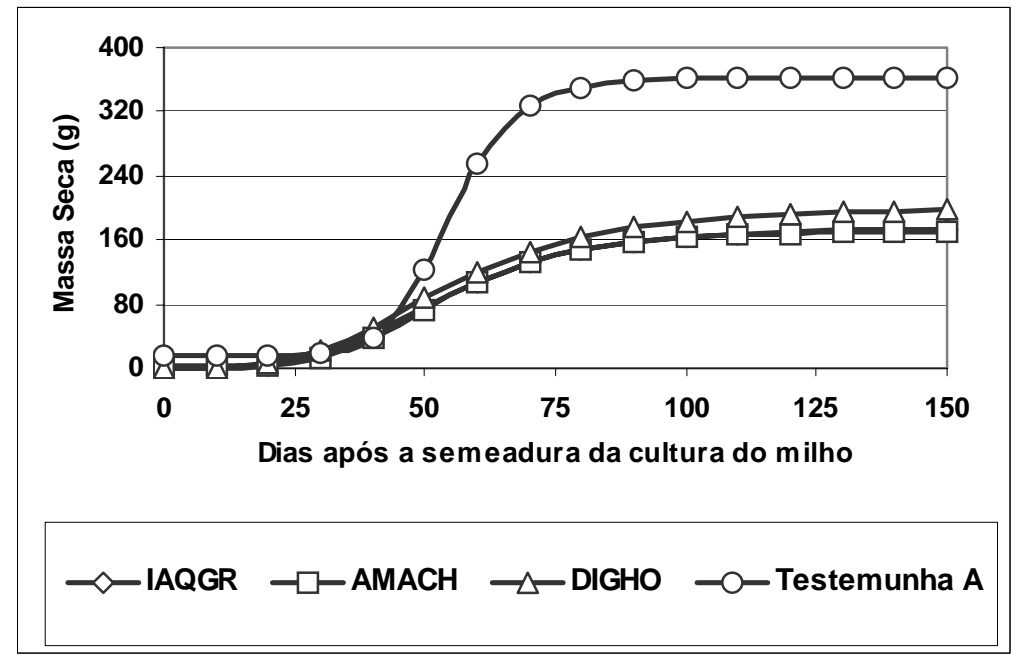

Figura 19 - Acúmulo de massa seca (g) por planta da cultura do milho solteiro (sem as culturas forrageiras), porém na presença das diferentes plantas daninhas e testemunha A onde cultura do milho foi cultivada sem competição (capinada) 
Tabela 12. Parâmetros do modelo logístico para a variável acúmulo área foliar $\left(\mathrm{cm}^{2}\right)$ por planta das plantas da cultura de milho quando na presença de diferentes culturas forrageiras e plantas daninhas, com a presença somente das plantas daninhas e milho solteiro (testemunhas)

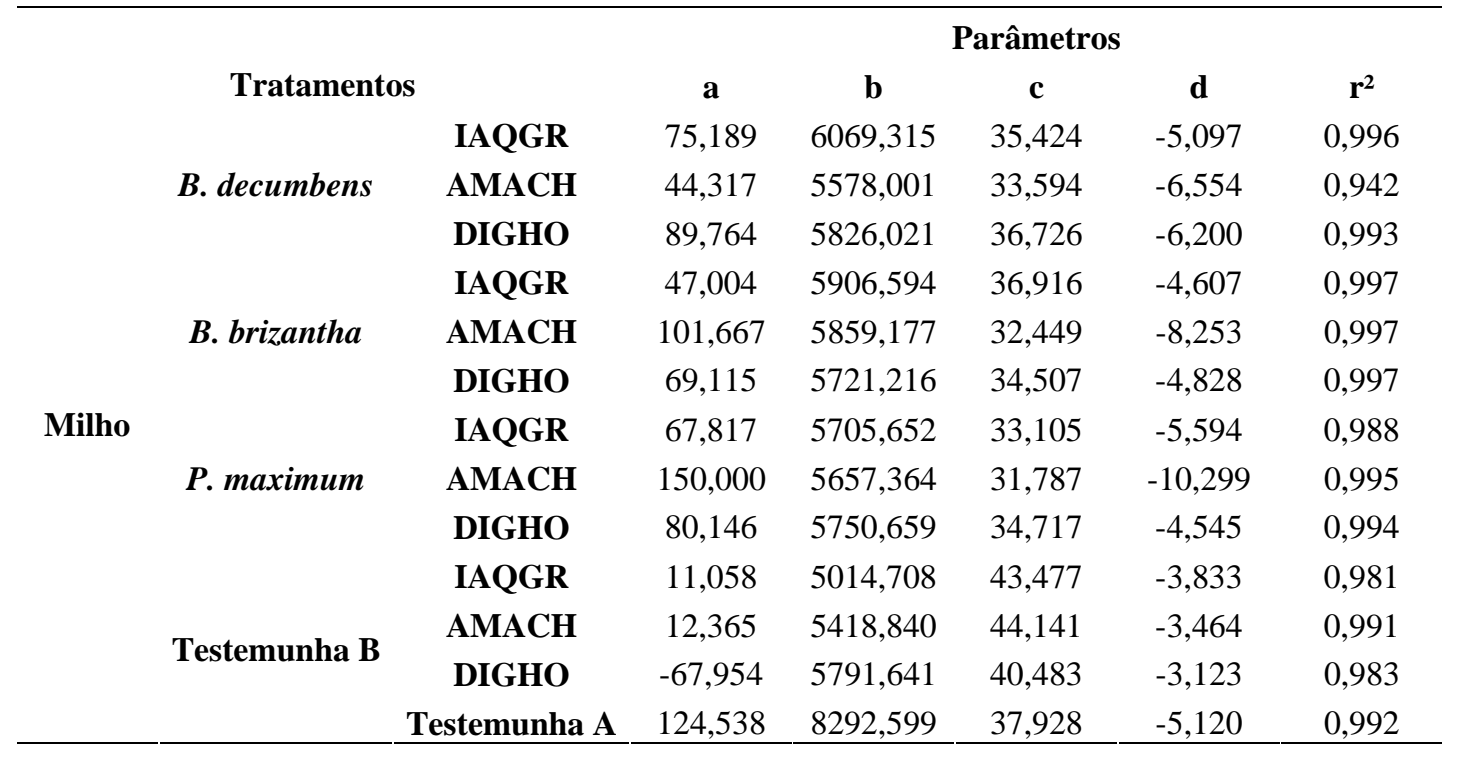

Testemunha $\mathrm{A}=$ milho solteiro sem interferência das plantas daninhas (capinada).

Testemunha $\mathrm{B}=$ milho solteiro com interferência da infestação natural das plantas daninhas.

Os resultados das figuras 23, 24 e 25, de acúmulo de área foliar $\left(\mathrm{cm}^{2}\right)$ pela planta da cultura do milho quando consorciado com as culturas forrageiras $B$. decumbens, $B$. brizantha e $P$. maximum, respectivamente, e as três plantas daninhas, indicam reduções semelhantes no acúmulo de área foliar $\left(\mathrm{cm}^{2}\right)$ por planta da cultura do milho. No entanto, quando se compara os resultados apresentados nas figuras 23, 24 e 25 com os resultados apresentados na figura 26, nota-se a viabilidade do sistema de produção agrícola integrando lavoura-pecuária, uma vez que num mesmo espaço de tempo e de lugar, podem-se obter colheitas de duas culturas quase que simultaneamente, ou seja, colheita da cultura de milho e colheita das culturas forrageiras. 
De acordo com Wallace (1991), uma importante característica da cultura do milho refere-se à capacidade do dossel da planta de absorver a maior parte da radiação fotossinteticamente ativa (RFA), sendo que menos de 10\% da RFA incidente chegue a atingir as camadas inferiores do dossel abaixo de 1,0m. Este fato permite que o consórcio da cultura do milho com gramíneas forrageiras seja um sistema de produção adequado, pois durante o crescimento e desenvolvimento da cultura do milho a maioria da radiação solar é disponibilizada para a cultura de grãos, porém pequena quantidade é disponibilizada para as culturas intercalares forrageiras e plantas daninhas. No final do ciclo da cultura do milho, quando esta não necessita de grande quantidade de RFA, sendo então disponibilizada para a cultura forrageira, a qual ocupa o nicho ecológico destinado para as plantas daninhas.

Na figura 26 pode ser observada a competitividade inter-específica da cultura do milho com as plantas daninhas I. grandifolia, A. hybridus e D. horizontalis (figura 26). A competitividade das três espécies de plantas daninhas foi semelhante, pois a área foliar acumulada $\left(\mathrm{cm}^{-2}\right)$ por planta destas espécies foi semelhante nas subparcelas com consórcio. Comparando-se os resultados das testemunhas A e B da tabela 3, observa-se que estes efeitos competitivos refletiram na produtividade da cultura do milho. 


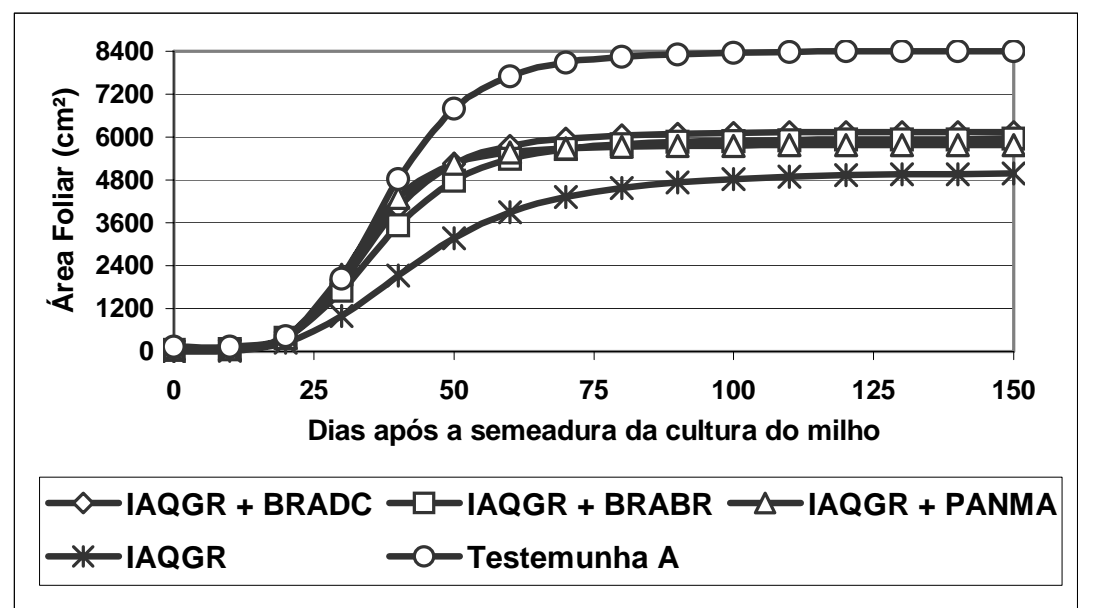

Figura 20 - Acúmulo de área foliar $\left(\mathrm{cm}^{2}\right)$ por planta da cultura do milho quando na presença da planta daninha I. grandifolia e de diferentes culturas forrageiras e IAQGR - sem a presença das culturas forrageiras e testemunha A do milho solteiro

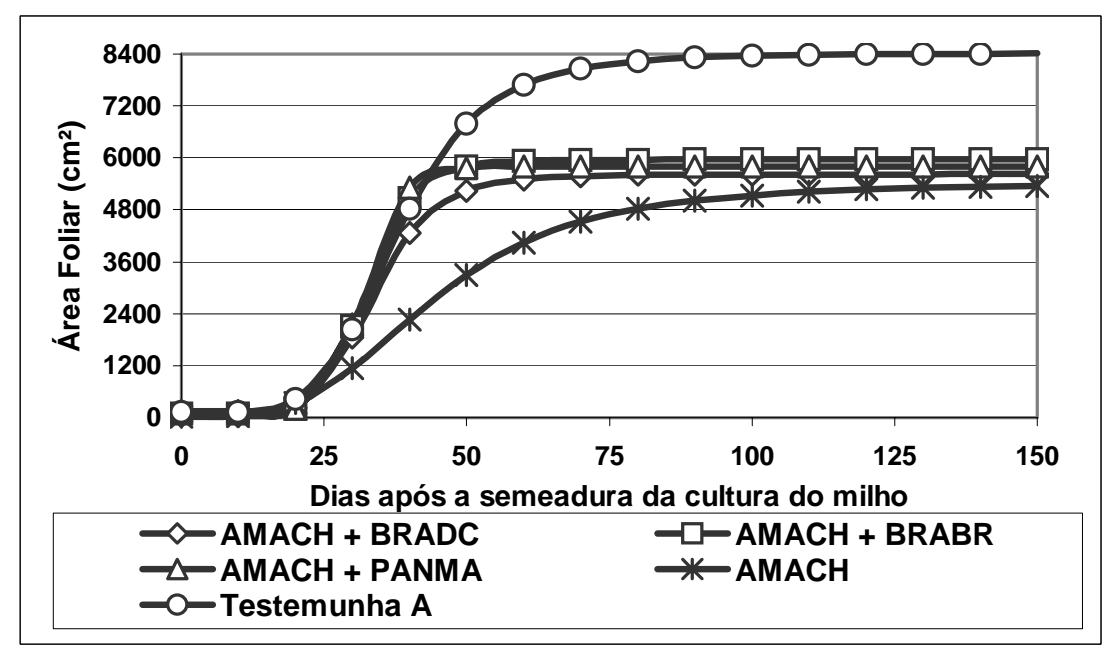

Figura 21 - Acúmulo de área foliar $\left(\mathrm{cm}^{2}\right)$ por planta da cultura do milho quando na presença da planta daninha $A$. hybridus e de diferentes culturas forrageiras e AMACH - sem a presença das culturas forrageiras e testemunha A do milho solteiro 


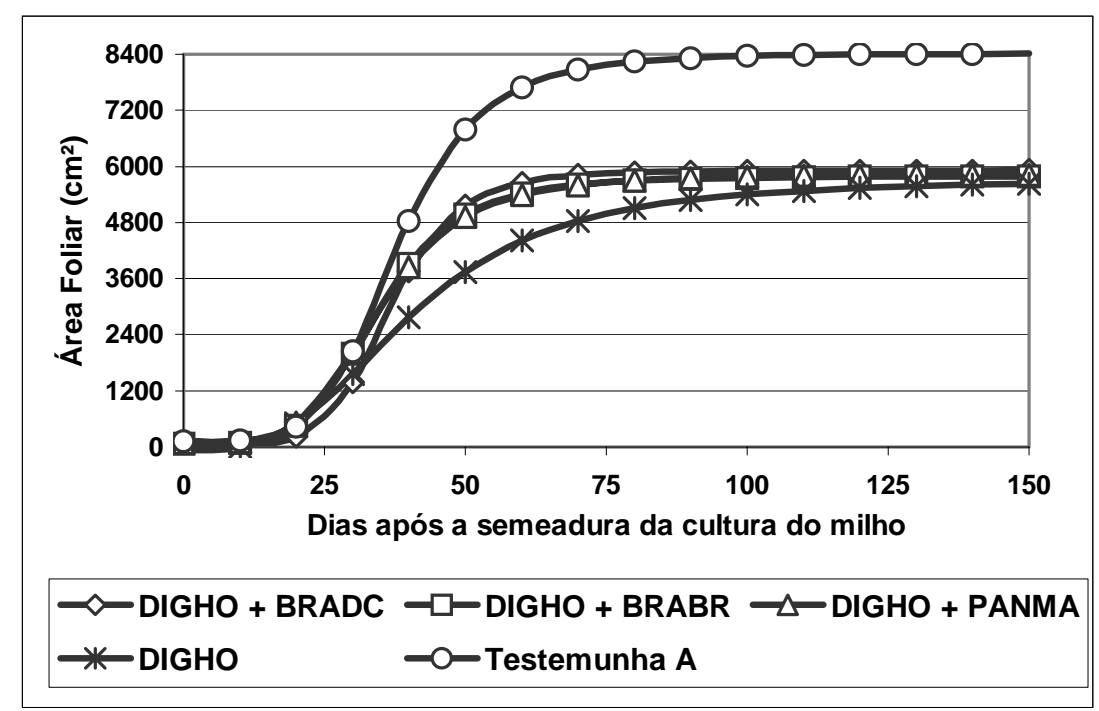

Figura 22 - Acúmulo de área foliar $\left(\mathrm{cm}^{2}\right)$ por planta da cultura do milho quando na presença da planta daninha $D$. horizontalis e de diferentes culturas forrageiras e DIGHO - sem a presença das culturas forrageiras e testemunha A do milho solteiro

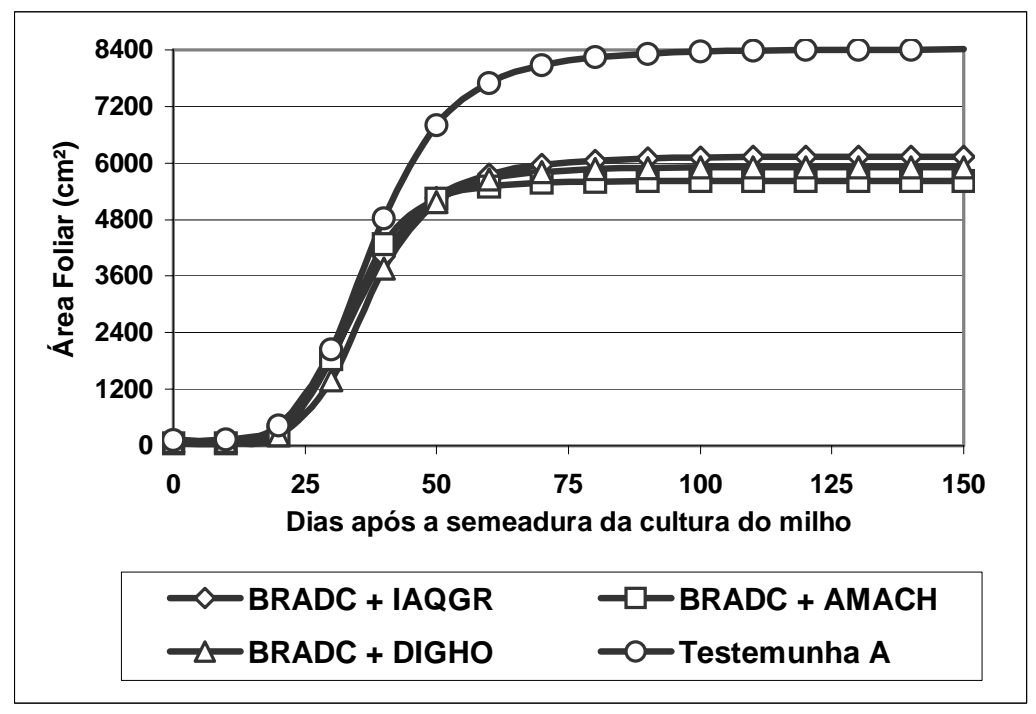

Figura 23 - Acúmulo de área foliar $\left(\mathrm{cm}^{2}\right)$ por planta da cultura do milho quando na presença da planta forrageira $B$. decumbens e de diferentes plantas daninhas e sem a presença da cultura forrageira (testemunha A) 


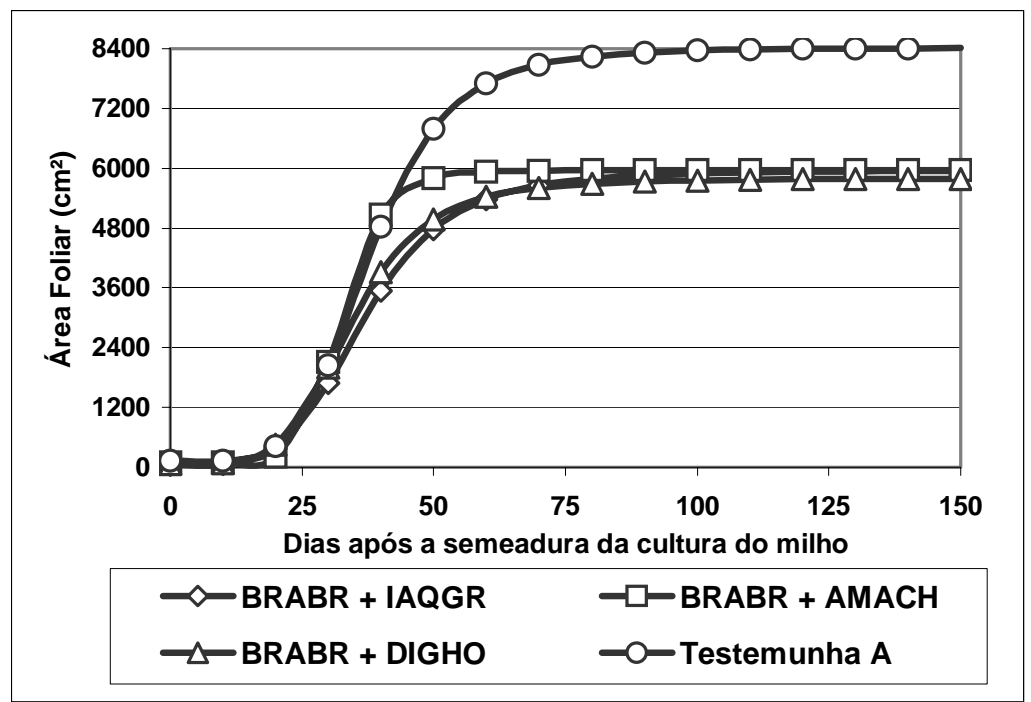

Figura 24 - Acúmulo de área foliar $\left(\mathrm{cm}^{2}\right)$ por planta da cultura do milho quando na presença da planta forrageira B. brizantha e de diferentes plantas daninhas e sem a presença da cultura forrageira (testemunha A)

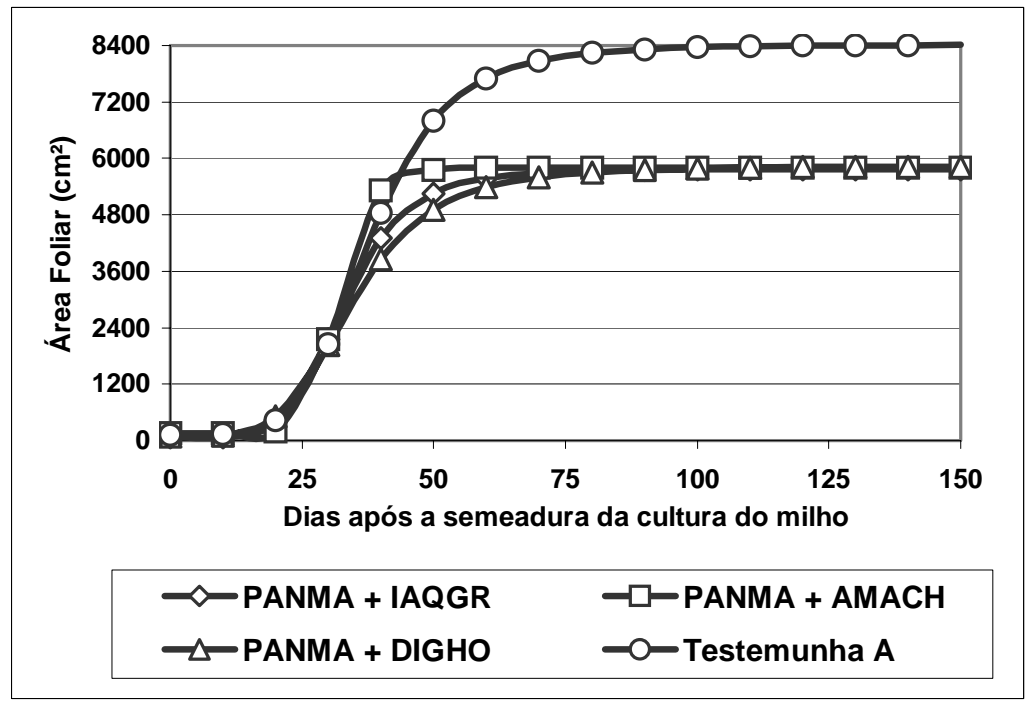

Figura 25 - Acúmulo de área foliar $\left(\mathrm{cm}^{2}\right)$ por planta da cultura do milho quando na presença da planta forrageira $P$. maximum e de diferentes plantas daninhas e sem a presença da cultura forrageira (testemunha A) 


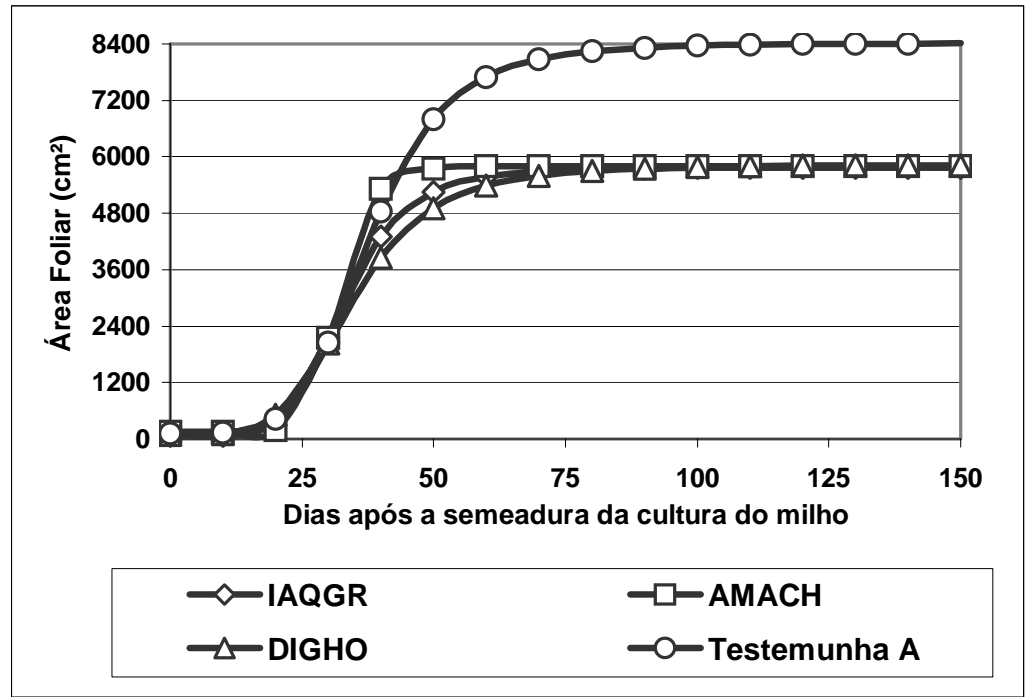

Figura 26 - Acúmulo de área foliar $\left(\mathrm{cm}^{2}\right)$ por planta da cultura do milho solteiro (sem as culturas forrageiras), porém na presença das plantas daninhas, e testemunha A, onde a cultura do milho foi cultivada sem competição (capinada) 


\subsection{Experimento em casa-de-vegetação}

Nas tabelas 13 e 14 estão apresentados os valores médios do número de plantas daninhas emergidas na primeira e segunda avaliação, realizadas respectivamente aos 30 e 60 dias após a instalação do experimento na casa-de-vegetação.

Na primeira avaliação, (tabela 13), verifica-se um aumento do banco de sementes da planta daninha I. grandifolia, nas parcelas com a forrageira B. decumbens, quando comparado com a testemunha. No entanto, as culturas forrageiras $B$. brizantha e $P$. maximum reduziram de forma significativa o banco de sementes desta planta daninha. $\mathrm{O}$ banco de sementes de $A$. hybridus foi significativamente menor em todos os tratamentos com culturas forrageiras, quando comparado com a testemunha, porém a maior intensidade de redução do banco de sementes aconteceu com a cultura forrageira $B$. brizantha (tabela 13). Os resultados de banco de sementes da planta daninha $D$. horizontalis foram de redução significativa do banco de sementes pelas três culturas forrageiras estudadas, porém as maiores reduções foram com as culturas forrageiras $B$. decumbens e B. brizantha.

Os resultados obtidos confirmam os mencionados por Buhler et al. (1997), os quais citam que a utilização de diferentes espécies vegetais num mesmo sistema de produção diversifica a pressão de seleção, alterando os padrões de distúrbios e reduzindo o tamanho do banco de sementes. Esta condição propicia diferentes modelos de competição e alelopatia, reduzindo, inclusive, a pressão de seleção para plantas daninhas específicas.

Na tabela 14, pode-se observar, em geral, menores valores de emergência de plantas daninhas, independentemente do tratamento considerado. Não se notou diferenças estatísticas no controle das plantas daninhas I. grandifolia, A. hybridus e $D$. horizontalis em solo cultivado anteriormente tanto com as culturas forrageiras quanto em solo não capinado em nenhum dos tratamentos utilizados.

Desta maneira, também neste caso, pode-se inferir que, em relação à $B$. decumbens, B. Brizantha e $P$. maximum, não houve diferenças significativas entre as 
médias dos tratamentos quando comparados entre si e nem quando comparados com o tratamento padrão.

Tabela 13. Número de plantas daninhas emergidas (plantas.bandeja ${ }^{-1}$ ) em solo cultivado com culturas forrageiras consorciadas com a cultura de milho, aos 30 dias após a instalação do experimento em casa-de-vegetação. Piracicaba, ESALQ/USP, junho e julho de 2004

\section{Culturas forrageiras}

B. decumbens

B. brizantha

P. maximum

Testemunha $\mathbf{D}^{(3)}$
Número de plantas daninhas emergidas (plantas.bandeja ${ }^{-1}$ )

$\begin{array}{ccc}\text { I. grandifolia } & \text { A. hybridus } & \text { D. horizontalis } \\ 15,9^{(2)} \mathrm{aA} & 7,9 \mathrm{bB} & 2,7 \mathrm{cC} \\ 1,3 \mathrm{cA} & 2,3 \mathrm{cA} & 3,1 \mathrm{cA} \\ 4,6 \mathrm{bBC} & 6,9 \mathrm{bAB} & 9,5 \mathrm{bA} \\ 17,2 \mathrm{aB} & 13,5 \mathrm{aB} & 28,9 \mathrm{aA}\end{array}$

C.V.\% 17,88

${ }^{1}$ Vegetação espontânea representada pela planta daninha capim-colchão (Digitaria horizontalis); ${ }^{2}$ Médias acompanhadas por mesma letra na linha (maiúscula) e na coluna (minúscula) não diferem estatisticamente entre si pelo teste de Tukey ao nível de 5\% de probabilidade; ${ }^{3}$ Testemunha $\mathrm{D}=$ onde as plantas daninhas foram mantidas sem as presenças das culturas do milho e forrageiras.

Os resultados observados nas tabelas 13 e 14, no entanto, corroboram com os resultados verificados por Ball e Miller (1990) e com os verificados por Schreiber (1992) que mencionam que em sistemas de consorciação e rotação de culturas foi encontrada menor quantidade de sementes de plantas daninhas no solo, quando comparado com monocultivo. 
Tabela 14. Número de plantas daninhas emergidas (plantas/bandeja) em solo cultivado com culturas forrageiras consorciadas com a cultura de milho, aos 60 dias após a instalação do experimento em casa-de-vegetação. Piracicaba, ESALQ/USP, junho e julho de 2004

\begin{tabular}{lccr}
\hline Culturas forrageiras & \multicolumn{3}{c}{ Número de plantas daninhas emergidas (plantas.band } \\
& I. grandifolia & A. hybridus & D. horizonta \\
B. decumbens & $1,3^{(2)} \mathrm{aB}$ & $3,5 \mathrm{aA}$ & $1,0 \mathrm{aB}$ \\
B. brizantha & $1,0 \mathrm{aA}$ & $1,3 \mathrm{bA}$ & $1,4 \mathrm{aA}$ \\
$\boldsymbol{P}$. maximum & $1,2 \mathrm{aB}$ & $2,8 \mathrm{aA}$ & $1,1 \mathrm{aB}$ \\
Testemunha $\mathbf{D}^{(3)}$ & $1,9 \mathrm{aB}$ & $3,9 \mathrm{aA}$ & $1,7 \mathrm{aB}$
\end{tabular}

C.V.\% 18,17

${ }^{1}$ Vegetação espontânea representada pela planta daninha capim-colchão (D.horizontalis); ${ }^{2}$ Médias seguidas pela mesma letra na linha (maiúscula) e na coluna (minúscula) não diferem estatisticamente entre si pelo teste de Tukey ao nível de 5\% de probabilidade;

${ }^{3}$ Testemunha $\mathrm{D}=$ onde as plantas daninhas foram mantidas sem as presenças das culturas do milho e forrageiras.

\subsection{Considerações gerais sobre a pesquisa}

O consórcio de duas espécies, preconizado no sistema de produção integrando lavoura-pecuária, coloca novamente em debate conceitos de aproveitar a presença de espécies associadas para intensificar o uso da terra e o sistema de produção, sem afetar a produtividade da cultura principal. Embora essa idéia possa parecer simples num primeiro momento, na verdade ela é extremamente complexa, pois depende do domínio de conhecimentos da competição inter-específica, em diferentes estádios fisiológicos das culturas e densidades de espécies consorciadas, das interações de doenças, pragas e plantas infestantes com estas espécies, das estratégias de colheita, dentre outras. Entretanto, atualmente, na atividade rural, o conceito de lavoura totalmente limpa está mudando, e tanto a pesquisa, o ensino e a extensão consideram sistemas consorciados, 
em que a presença de plantas daninhas da família das gramíneas e/ou de forrageiras com baixo poder competitivo inicial com as culturas, que não são hospedeiras de doenças e pragas, promovem benefícios, como controle de erosão, reciclagem de nutrientes, proteção e melhoria das propriedades físicas, químicas e biológicas do solo, inibição do crescimento de fungos patogênicos no solo e que, ainda, podem servir como alimento para o gado após a colheita da cultura granífera.

Assim, as práticas agrícolas preconizadas no sistema de integração lavourapecuária, minimizam a competição precoce da forrageira, evitando redução do rendimento das culturas anuais e permitem, após a colheita destas, uma substancial produção de forragem de qualidade e/ou produção de palhada para o sistema de plantio direto.

Desta forma, pode-se considerar que a coexistência de sistemas bem estruturados de produção de grãos e pecuária, será um fator que contribuirá para que esse sistema de produção integrando lavoura- pecuária seja adotado de forma harmoniosa, além de se constituir num novo paradigma da sustentabilidade. 


\section{CONCLUSÕES}

a) O sistema de produção da cultura do milho em consórcio com as culturas forrageiras B. decumbens, Brachiaria brizantha e Panicum maximum, reduz, de maneira significativa, a infestação das plantas daninhas no sistema, quando comparado com as culturas de milho solteiro sem qualquer intervenção de manejo de plantas daninhas.

b) A cultura forrageira Brachiaria brizantha em consórcio com a cultura de milho, de maneira geral, foi a mais eficiente na redução da infestação das plantas daninhas Ipomoea grandifolia, Amaranthus hybridus e Digitaria horizontalis, quando comparada com as culturas forrageiras Brachiaria decumbens e Panicum maximum.

c) A cultura forrageira Panicum maximum em consórcio com a cultura de milho, foi a espécie que mais produziu matéria verde, podendo-se inferir que foi a planta menos prejudicada pela somatória das interferências negativas da cultura do milho e das plantas daninhas estudadas.

d) $\mathrm{O}$ maior rendimento do milho em ton.ha ${ }^{-1}$ foi obtido no tratamento onde se utilizou a cultura forrageira Panicum maximum, seguida pela Brachiaria brizantha e Brachiaria decumbens, independente da infestação da planta daninha.

e) As três culturas forrageiras testadas em consórcio com a cultura do milho, foram adequadas para o sistema de integração lavoura-pecuária, por: i) permitiu bom rendimento da cultura do milho; ii) propiciou alta produção de massa verde das 
culturas forrageiras e, iii) reduziu a infestação e recrutamento do banco de sementes das plantas daninhas testadas.

f) A planta daninha que mais interferiu no rendimento do milho foi Ipomoea grandifolia, seguida de Amaranthus hybridus e Digitaria horizontalis.

g) As três plantas daninhas estudadas interferiram negativamente na produção de matéria verde das três culturas forrageiras testadas de forma semelhante, quando em comparação com a testemunha, onde as culturas forrageiras foram cultivadas sem a presença de plantas daninhas e da cultura do milho.

h) O efeito direto da utilização de culturas forrageiras, consorciadas com a cultura do milho, na redução do recrutamento do banco de sementes, e conseqüente alteração na dinâmica populacional de plantas daninhas, permite inferir que a técnica de integração lavoura-pecuária com as espécies de culturas estudadas, pode fazer parte do manejo integrado de plantas daninhas, além de contribuir com outros benefícios inerentes a utilização desta prática agrícola.

i) As curvas de crescimento das plantas daninhas indicam que o efeito supressivo das três espécies de plantas forrageiras em consórcio com a cultura de milho, foram semelhantes para as três espécies de plantas daninhas utilizadas na experimentação.

j) A infestação das plantas daninhas interferiu negativamente nas curvas de crescimento dos perfilhos das plantas forrageiras em consorciação com a cultura do milho.

k) Apesar do efeito negativo nas curvas de crescimento das plantas de milho causado pelas plantas daninhas e plantas forrageiras, esta redução de crescimento não inviabiliza o sistema de produção lavoura-pecuária, pois a produtividade tanto das culturas forrageiras quanto da cultura do milho foram adequadas para um sistema de produção econômico nas condições edafo-climáticas brasileiras. 


\section{REFERÊNCIAS BIBLIOGRÁFICAS}

ALCÂNTARA, P.B.; BUFARAH, G. Plantas forrageiras: gramíneas e leguminosas. São Paulo: Nobel, 1999. 162p.

ALMEIDA, F.S. Alelopatia e as plantas. Londrina: IAPAR, 1988, 60p. (IAPAR, Circular Técnica, 53).

ALVIM, M.J.; BOTREL, M. de A.; S.; SALVATI, J.A. Métodos de estabelecimento de Brachiaria decumbens em associação à cultura do milho. Revista da Sociedade Brasileira de Zootecnia, v.18, n.5, p.417-425, 1989.

ALVIM, M.J.; BOTREL, M. de A.; VERNEQUE, R. da S.; SALVATI, J.A. Aplicação de nitrogênio em acessos de Brachiaria. 1. Efeito sobre a produção de matéria seca. Pasturas Tropicales, v.12, n.2, p.2-6, 1990.

AMBROSANO, E.J; WUTKE, E.B.; BRAGA, N.R.; MIRANDA, M.A.C. de. Leguminosas: alternativas para produção ecológica de grãos em diferentes regiões agroecológicas do Estado de São Paulo. In: AMBROSANO, E.J. Agricultura Ecológica. Guaíba: Agropecuária, 1999. 398p.

AMBROSANO, E.J. Leguminosas adubo verde: instrumento de manejo ecológico de fertilidade do solo. Revista Agroecologia Hoje, v.3, n.8. p.24. 2001. 
ANDRADE, R.V. de. Importância e uso de banco de germoplasma para o melhoramento genético vegetal - milho. In: UDRY, C.V.; DUARTE, W. Uma história brasileira do milho - o valor dos recursos genéticos. Brasília: Paralelo 15, 2000. 136p.

AZCÓN, R.; RUBRO, R.; BAREA, J.M. Selective interactions between different species of mycorrhizal fungi and Rhizobium meliloti strains and theirs effects on growth, N2 fixation and nutrition of Medicago sativa L. New Phytology, n.117. p.399-404, 1991.

BALL, D.A.; MILLER, S.D. Weed seed population response to tillage, and herbicide use in three irrigated cropping sequence. Weed Science, v.38, p.511-517, 1990.

BARRALIS, G.; CHADOEUF, R. Potential de semencier du terres arables. Weed Research, v.27, p.417-424, 1987.

BASTOS, E. Guia para o cultivo do milho. São Paulo: Editora Ícone (Coleção Brasil Agrícola) 1987. 190p.

BAUMANN, D.T.; BASTIAANS, L.; KROPFF, M.J. Effects of intercropping on growth and reproductive capacity of late-emerging Senecio Vulgaris, with special reference to competition for light. Annals of Botany, v.87, p.209-217, 2001.

BEGNA, S.H. Morphology and yield response to weed pressure by corn hybrids differing in canopy architeture. European Journal of Agronomy, v.14, n.4, p.293302, 2001.

BENINCASA, M.M.P. Análise de crescimento de plantas (Noções Básicas). Jaboticabal: UNESP/FUNEP, 1988. 42p. 
BODDEY, R.M.: RAO, I.M.; THOMAS, R.J. Nutrient cycling and environmental impact of Brachiaria pastures. In: MILES, J.W.; MAASS, B.L.; VALLE, C.B. do (Ed.). Brachiaria: biology, agronomy and improvement. Cali: CIAT; Brasília: EMBRAPA - CNPGC, 1996. p.72-86.

BROCH, D. L.; PITOL, C.; BORGES, E. P. Integração Agricultura-Pecuária: plantio direto da soja sobre pastagem na integração agropecuária. Maracaju - MS,: FUNDAÇÃO MS para Pesquisa e Difusão de Tecnologias Agropecuárias, 1997. 24p. (FUNDAÇÃO MS, Informativo Técnico, 01/97).

BUHLER, D.D. Influence of tillage systems on weed populations dynamics and management in corn and soybean in the central USA. Crop Science, v.35, p.12471258, 1995.

BUHLER, D.D.; HARTZLER, R.G.; FORCELLA, F. Implications of weed seedbank dynamics to weed management. Weed Science, v.45, p.329-336, 1997.

BRUCE, R.R.; HENDRIX, P.F.; LANGDALE, G.W. Role of cover crops in recovery and maintenance of soil productivity. In: HARGROLE, W.L., Ed. Cover crops for clean water. Ankeny: Soil and Water Conservation Society, 1991. p.109-114.

BULISANI, E. A.; BRAGA, N. R.; ROSTON, A. J. Utilização de leguminosas como cobertura de solo em sistemas de adubação verde ou rotação de culturas. In: Encontro Paulista de Plantio Direto, p.63-70, 1987. 
CÁCERES, N.T.; ALCARDE, J.C. Adubação verde com leguminosas em rotação com cana-de-açúcar (Saccharum spp.). REVISTA STAB, v.13, n.5, p.16-20. Maio/Jun. 1995.

CAETANO, R.S. Dinâmica do banco de sementes de plantas daninhas na cultura dos citros (Citrus sinensis C.) submetida a diferentes sistemas de manejo. Tese (Doutorado)-Piracicaba, 2000. 105p. Escola Superior de Agricultura "Luiz de Queiroz”, Universidade de São Paulo.

CALEGARI, A.; ALCÂNTARA, P.B.; MIYASAKA, S.; AMADO, T.J.C. Aspectos gerais da adubação verde. 2.ed. In: COSTA, M.B.B. da. Adubação verde no sul do Brasil. Rio de Janeiro: AS-PTA - 1993. p.1-58.

CAVALCANTI, G.S. Cultura de milho. Campinas: Instituto Campineiro de Ensino Agrícola. 1987. 38p.

CARDINA, J.; SPARROW, D.A. Comparison of methods to predict weed seedling populations from the soil seed bank. Weed Science, v.44, p.46-51, 1996.

CARVALHO, M.M.; NAKAGAWA, J. Sementes: ciência, tecnologia, produção. Campinas: Fundação Cargill, 1983. 429p.

CARVALHO, Y.M.C. de. Agroecologia e regulação: contribuição metodológica para o fortalecimento de um processo social. In: AMBROSANO, E.J. Agricultura Ecológica. Guaíba: Agropecuária, 1999. 398p.

CAVERS, P.B.; BENOIT, D.L. Seed banks in arable land. In: LECK, M.A.; PARKER, V.T.; SIMPSON, R.L. Ecology of soil seed banks. London: Academic Press, 1989. p. 309-328. 
CHADOEUF-HANNEL, R. La dormance chez les semences des mauvaises herbs. Agronomie, v.5, p.761-772, 1985.

CHOU, C. H. Phytotoxic substances in twelve subtropical grasses. I. Additional evidences of phytotoxicity in the aqueous fractions of grass extracts. Botanical Bulletin of Academia Sinica, v.18 p.131-141, 1977.

CHOU, C. H.; CHANG, S.J.; CHENG, C.M.; WANG, Y.C.; HSU, F.H.; DEN, W.H. The selective allelophatic interaction of pasture-forest intercropping in Taiwan. II. Interaction between kikuyu grass and three hardwood plants. Plant and Soil, v.116, p.207-215, 1989.

CHRISTOFFOLETI, P. J. Controle de Brachiaria decumbens Stapf. e de Cyperus rotundus (L). em área de cana-de-açúcar ( Saccharum spp ) através da técnica de rotação com amendoim (Arachis hypogaea L.) integrada ao uso de herbicidas. Piracicaba, Dissertação (Mestrado)-Escola Superior de Agricultura "Luiz de Queiroz”, 1988. 117p. Universidade de São Paulo.

CHRISTOFFOLETI, P.J.; PASSINI, T. Manejo integrado de plantas daninhas na cultura do feijão. In: FANCELLI, A.L.; DOURADO NETO, D. Feijão irrigado: Estratégias básicas de manejo. Piracicaba: ESALQ, Departamento de Produção Vegetal, Ed. Publique, 1999. p.80-97.

CHRISTOFFOLETI, P. J.; MENDONÇA, C.G. de. Controle de plantas daninhas na cultura de milho: enfoque atual. In: FANCELLI, A.L.; DOURADO NETO, D. Milho: tecnologia e produtividade. Piracicaba: ESALQ/USP/LPV, 2001. 259p. 
CHASTAIN, T.G.; GRABE, D.F. Spring establishment of orchad grass weed crops with cereal companion crops. Crop Science, v.29, p.466-471, 1989.

CLEMENTS, D.R.; BENOIT, D.L.; MURPHY, S.D. et al. Tillage effects on weed seed return and seed bank composition. Weed Science, v.44, p.314-322, 1996.

COBLE, H. D. Crop rotation monoculture - weed control. Crops and Soil Magazine. American Society Agronomy, v.32, n.5, p.1-32, 1980.

COBUCCI, T. Manejo integrado de plantas daninhas em sistema de plantio direto. In: ZAMBOLIM, L. Manejo integrado fitossanidade: cultivo protegido, pivô central e plantio direto. Viçosa: 2001. 722p.

COBUCCI, T. Sistema Santa Fé: integração agricultura pecuária. In: DOURADO NETO, D.; FANCELLI, A.L. Feijão irrigado - tecnologia e produtividade. Piracicaba: Departamento de Produção Vegetal, ESALQ, USP, 2003. 165p.

CÔME, D. Germination In: MAZLIAK, P. Croisance et developpement. Physiologie Vegetale II. Paris: Hermann, 1982. p.129-225.

COLOZZI FILHO, A.; BALOTA, E.L.; CHAVES, J.C.; ANDRADE, D.S. Alterações na biomassa microbiana do solo e em alguns de seus componentes, em função da adubação verde do cafeeiro. In: SIMPÓSIO DE PESQUISA DOS CAFÉS DO BRASIL, 1. Resumos expandidos. Poços de Caldas: MG. 2000. p.1393-1395. 
COLOZZI FILHO, A.; ANDRADE, D.S. de; BALOTA, E.L. O manejo dos agrossistemas e a microbiota do solo. Revista Agroecologia Hoje, v.2, n.8, p.2223. Abril/Maio 2001.

CORRÊA, L.A.; HAAG, H.P. Níveis críticos de fósforo para o estabelecimento de gramíneas forrageiras em latossolo vermelho-amarelo, álico. I: ensaio em casa de vegetação. Scientia Agrícola, v.50, n.1, p.99-108, 1993 a.

CORRÊA, L.A.; HAAG, H.P. Níveis críticos de fósforo para o estabelecimento de gramíneas forrageiras em latossolo vermelho-amarelo, álico. II: experimento de campo. Scientia Agrícola, v.50, n.1, p.99-108, 1993 b.

DEHAAN, R. L.; WYSE, D. L.; EHLKE, N. J. et al. Simulation of spring-seeded smother plants for weed control in corn. Weed Science. v.42, p.35-43, 1994.

DERPSCH, R.; CALEGARI, A. Guia de plantas para adubação verde de inverno. Londrina: IAPAR, 1985. 96p. (Documentos IAPAR, 9).

DERPSCH, R.; SIDIRAS, N.; HEINZMANN, F.X. Manejo do solo com coberturas verdes de inverno. Pesquisa Agropecuária Brasileira, v. 20, p.761-73, jul. 1985.

DERPSCH, R.; ROTH, C.H.; SIDIRAS, N.; KOPKE, U. Controle da erosão no Paraná, Brasil: Sistema de cobertura do solo, plantio direto e preparo conservacionista do solo. Londrina: PR, GTZ, 1991. 274p. 
DESSAINT, F.; CHADOEUF, R.; BARRALIS, G. Etude de la dynamique communauté adventice: III. Influence a long terme dês techniques culturales sur la composition spécifique du stock semencier. Weed Research, v.30, p.319-30, 1990.

DIAS FILHO, M.B. Growth and biomass allocation of the $\mathrm{C}_{4}$ grasses Brachiaria brizantha and Brachiaria humidicola under shade. Pesquisa Agropecuária Brasileira, v.35, n.12, p.2335-2341, 2000.

DIAS FILHO, M.B. Photosynthetic light response of $\mathrm{C}_{4}$ grasses Brachiaria brizantha and Brachiaria humidicola under shade. Scientia Agricola, v.59, n.1, p.65-68, 2002.

DUARTE, J.M.; PÉREZ, H.E.; PEZO, D.A.; ARZE, J.; ROMERO, F.; ARGEL, P.J. Producción de maiz (Zea mays L.) soya (Glycine max) y caupí (Vigna unguiculata (L.) Walp) sembreados en associción con gramíneas en el trópico húmedo. Pasturas Tropicales, v.17, n.2, p.12-19, 1995.

DURIGAN, J.C. Controle químico de plantas daninhas na citricultura. Jaboticabal: FUNEP/FCAV-UNESP, 1988. 18p.

EBELHAR, S.A.; FRYE, W.W.; BLEVINS, R.L. Nitrogen from legume cover crops for no-tillage corn. Agronomy Journal, v.76, p.51-55, Jan./Fev. 1984.

ECHTENKAMP, G.W.; MOOMAW, R.S. No-till corn production in a living mulch system. Weed Technology. v.3, p.262-266, 1989.

ELKINS, D., FREDERKING, D., MARASHI, R. et al. Living mulch for no-tillage corn and soybeans. Journal of Soil and Water Conservation. v.38, p.431-433, 1983. 
EMPRESA BRASILEIRA DE PESQUISA AGROPECUÁRIA. Centro Nacional de Pesquisa de Solos. Sistema brasileiro de classificação de solos. Brasília, 1999. 412p.

ENACHE, A. J.; ILNICKI, R. D. Weed control by subterranean clover used as living mulch. Weed Technology, v.4, p.534-538, 1990.

FANCELLI, A.L. Plantas alimentícias: guia para aula, estudos e discussão. Piracicaba: ESALQ, Departamento de Agricultura, 1986. 131p.

FANCELLI, A.L. Tecnologia da produção do milho para alta produtividade. Piracicaba: ESALQ, Departamento de Agricultura, 1994. 223p.

FANCELLI, A.L.; DOURADO NETO, D. Milho: Fisiologia da produção. In: SEMINARIO SOBRE FISIOLOGIA DA PRODUÇÃO E MANEJO DE ÁGUA E DE NUTRIENTES NA CULTURA DO MILHO DE ALTA PRODUTIVIDADE. Piracicaba: ESAL/USP. POTAFÓS, 1996. p.1-30.

FANCELli, A.L.; DOURADO NETO, D. Produção de Milho. Guaíba: Agropecuária, 2000. 360p.

FANCELLI, A.L.; DOURADO NETO, D. Milho: tecnologia e produtividade. Piracicaba: ESALQ/USP/LPV, 2001. 259p. 
FERNANDEZ-QUINTANILLA, C. Studying the population dynamics of weeds. Weed Research, v.25, n.6, p. 443-447, 1988.

FERNÁNDEZ-QUINTANILLA, C.; SAAVEDRA, M.S.; GARCIA TORRES, L. Ecologia de las malas hierbas. In: GARCIA TORRES, L. FERNÁNDEZQUINTANILLA, C. Fundamentos sobre malas hierbas y herbicidas. Madrid: Mundi-Prensa, 1991. cap.2, p.49-69.

FERREIRA, A.M. Efeitos de adubos verdes nos componentes de produção de diferentes cultivares de milho. Lavras, 1996. 70p. Dissertação (Mestrado) Universidade Federal de Lavras.

FERREIRA, A.A.; SILVA, J.F. da; FERREIRA, F.A.; FERREIRA, L.R.; SILVA, J.F. da. Controle de plantas daninhas. Brasília, DF: ABEAS, Viçosa, MG: UFV, 2001. 203p.

FLECK N.G. Princípios do controle de plantas daninhas. Porto Alegre: UFRGS, 1992. 70p.

FLECK N.G.; RIZZARDI, M. A.; AGOSTINETTO, D. et al. Interferência de picãopreto e guanxuma com a soja: efeitos da densidade de planta e época relativa de emergência. Ciência Rural, v.34, n.1, p.41-48, 2004.A

FRANÇA, V.; MOREIRA, T. Agricultor ecológico: técnicas alternativas de produção. São Paulo: Nobel. 1988. 75p. 
FRANCO, A.A.; SOUTO, S. M. Contribuição da fixação biológica de N2 na adubação verde. Adubação Verde no Brasil. Campinas: Fundação Cargill, 1984. p.199-215.

FRYE, W.W.; VRACO, J.J.; BLEVINS, R.L.; SMITH, M.S.; CORAK, S.J. Role of annual legume cover crops in efficient use of water and nitrogen. In: HARGROVE, W.L., (Ed.). Cropping strategies for use of water and nitrogen. Madison: ASACSSA-SSSA, 1988. p.154. (ASA-CSSA-SSSA. Special Publication, 51).

FREITAS, J. A. D.; COELHO, M. A.; FERREYRA, H. F. F. Efeitos de corretivos químicos e materiais orgânicos no movimento da água e estrutura do solo salinosódico. Revista Brasileira de Ciência do Solo, n.8, p.261-264, 1984.

HALE, M.G.; ORCUTT, D.M. The physiology of plant under stress. New York: John Willey, 1987. 206p.

HARTWIG, N. L. Influence of crownvetch living mulch on dandelion invasion in corn. Proceeding Northeast. Weed Science, v.43, p.25-28, 1989.

HOLT, J. Plant response to light: a potential tool for weed management. Weed Science, v.43, p.474-482, 1995.

IGUE, K. Dinâmica da matéria orgânica e seus efeitos na propriedade do solo. Adubação verde no Brasil. Campinas: Fundação Cargill, 1984. p.232-267. 
JEFFERIES, R.A. Cultivars responses to water stress in potato: effects of shoot and roots. New Phytologist, v.123, p.491-498, 1993.

KEATING, B.; CARBERRY, P.S. Resource capture and use in intercropping: solar radiation. Fields Crops Research, v.34, p.273-301, 1993.

KLUTHCOUSKI, J.; AIDAR, H. Implantação, condução e resultados obtidos com o sistema Santa Fé. In: KLUTHCOUSKI, J.; STONE, L.F.; AIDAR, H. (Ed.). Integração Lavoura-Pecuária. Santo Antonio de Goiás: Embrapa Arroz e Feijão, 2003. p.407-441.

KISSMANN, K.G. Plantas infestantes e nocivas. São Paulo: BASF Brasileira 1992, v.2. 797p.

KISSMANN, K.G. Plantas infestantes e nocivas. São Paulo: BASF Brasileira 1997, v.1. 825p.

KOHL, D. H.; SHEARER, G. B.; COMMONER, B. Fertilizer nitrogen contribution to nitrate in surface water, in a corn belt watershed. Science, v.174, p.1331-1334, 1971.

LOBATO, E.; KORNELIUS, E.; SANZONOWICZ, C. Adubação fosfatada em pastagens. In: SIMPÓSIO SOBRE ADUBAÇÃO E CALAGEM DE PASTAGENS, 1., Nova Odessa, 1985. Calagem e adubação de pastagens. Piracicaba, SP: POTAFOS, 1986. p.145-174. 
LORENS, G.F.; BENNETT, J.M.; LOGGALE, L.B. Differences in drought resistance between two corn hybrids. I.Water relation and root length density. Agronomy Journal, v.79, p.802-807, 1987.

LORENZI, H. Plantas daninhas no Brasil: terrestres, aquáticas, parasitas, tóxicas e medicinais. Nova Odessa, SP. O Autor, 1982. 425p.

MACEDO, M.C.M.; ZIMMER, A.H. Implantação de pastagens de Brachiaria brizantha cv. Marandu em plantio simultâneo com milho em sucessão à soja em Mato Grosso do Sul. In: REUNIÃO ANUAL DA SBZ, 27., Anais. Campinas-SP: SBZ, 1990. p.290.

MACHADO, L.A.Z. Manejo de pastagens em sistema integrado lavoura/pecuária. Direto no Cerrado, v.6, n.21, p.10, 2001.

MANNERING, J.V.; MEYER, L.D. The effects of various rates of surface mulch on infiltration and erosion. Soil Science American Procceeding, v.27, p.84-86, 1963.

MARTINEZ, H.E.P. Niveis críticos de Fósfofo em Brachiaria decumbens (Stapf) Prain, Brachiaria humidicola (Rendle) Schweickerdt, Digitaria decumbens Stente, Hipharrhenia rufa (Ness) Stapf, Melinis minutiflora Pal de Beauv, Panicum maximum Jacq e Pennisetum purpureum Schum. Piracicaba, 1980. 90p. Dissertação (Mestrado) - Escola Superior de Agricultura “Luiz de Queiroz”, Universidade de São Paulo. 
MASCARENHAS, H.A.A.; HIROCE, R.; BRAGA, N.R.; MIRANDA, M.A.C. de; BULISANI, E.A.; POMER, C.V.; SAWAZAKI, E.; GALLO, E.; PEREIRA, J.C.V.N.A Efeito do nitrogênio residual de soja na produção de milho. 2. ed. Campinas: Instituto Agronômico, 1986. 24p. (IAC. Boletim Técnico, 58).

MATTOS, H.B.; COLAZZA, M.T. Micronutrientes em pastagens. In: SIMPÓSIO SOBRE CALAGEM E ADUBAÇÃO DE PASTAGENS, 1., Nova Odessa, 1985. Anais Piracicaba: Associação Brasileira para Pesquisa da Potassa e do Fosfato, 1986. p.233-256.

McWILLIAM, J.R. The national and international importance of drought and salinity effects on agricultural production. Australian Journal of Plant Physiology, v.35, p.1-13, 1986.

MORRIS R.A.; GARRIT, D.P. Resource capture and utilization in intercropping water. Fields Crop Research, v.34, p.303-317, 1993.

MEDEIROS, G.B.; CALEGARI, A.; GAUDÊNCIO, C. The effects of residues produced by lupin (L. Albus) and oat (Avena sativa Schieb) growing in pure stand and in mixed cropping on corn yields. In: INTERNATIONAL LUPIN CONFERENCE 6., Pucon, 1990. Resumos. Pucon: 1990.

MELLO, F. A. F.; BRASIL SOBRINHO, M. O. C. Efeitos da incorporação de resíduos de mucuna preta, Crotalaria juncea L. e feijão baiano. In: Influência sobre a produção de arroz. Revista de Agricultura. v.35, n.1, p.33-40, 1960. 
MITCHELL, W.H.; TEEL, M.R. Winter annual cover crops for no-tillage corn production. Agronomy Journal, v.69, p.569-73, July/Aug. 1977.

MIYASAKA, S. Histórico do estudo de adubação verde, leguminosas viáveis e suas características. Campinas: Fundação Cargill, 1984. p.64-123.

MOHLER, C. L. Effects of tillage and mulch on weed biomass and sweet corn yield. Weed Technology, v.5, p.545-552, 1991.

MUZILLI, O. Influência do sistema de plantio direto, comparado ao convencional, sobre a camada arável do solo. Revista Brasileira de Ciência do Solo, v.7, p.95-102, 1983.

MUZILLI, O.; OLIVEIRA, E.L. de; CALEGARI, A. Adubação do milho. Campinas: Fundação Cargill, 1989. 29p.

NICHOLSON, A., G.; WIEN, H.C. Screening of turf grasses and clovers for use as living mulches in sweet corn and cabbage. Journal of American Society of Horticultural Science, v.108, p.1071-1076, 1983.

NUNES, S.G.; BOOCK, A.: PENTEADO, M.I.O.; GOMES, D.T. Brachiaria brizantha cv. Marandu. Campo Grande: EMBRAPA, CNPGC, 1985. 31p. (EMBRAPA. CNPGC. Documentos, 21) 
OLIVEIRA, E. Efeito da Crotalaria juncea L. na eficiência agronômica, econômica e energética de culturas em sucessão sob plantio direto. Piracicaba, 1996. 95p. Dissertação (Mestrado)-Escola Superior de Agricultura “Luiz de Queiroz”, Universidade de São Paulo.

PIAMONTE, R. P. Seminário sobre novas tendências de manejo do solo: húmus e microorganismos. Instituto de Cooperativismo e Associativismo. São Paulo: CATI/SAA, 1996,. 63p.

PITELLI, R.A. Interferência de plantas daninhas em culturas. Informe Agropecuário, v.120, n.11, p.16-27, 1985.

POWER, J.F.; FOLLETT, R.F.; CARLSON, G.E. Legumes in conservation tillage systems: a research perspective. Journal of Soil and Water Conservation, v.38, n.3, p.217-218, 1983.

PREMAZZI, L.M. Saturação por bases como critério para recomendação de calagem em cinco forrageiras tropicais. Piracicaba. 1991. 215p. Dissertação (Mestrado) - Escola Superior de Agricultura “Luiz de Queiroz”, Universidade de São Paulo.

PRIMAVESI, A.M. Solo: manejo nos trópicos. Revista Guia Rural Abril. Ed. Abril Cultural, v.11, n.06, p.24-37, 1986.

RADOSEVICH, S. Physiological aspects of competition. 2 ed. Weed Ecology: implications for weed management. 2 ed. New York: Wiley, 1996. p.217-301. 
RAJCAN, I.; SWANTON, C. Understanding maize-weed competition: resource competition, light quality and the whole plant. Field Crop Research, v.71, p.139150, 2001.

REICOSKY, D.C. Crop residue management: soil, crop, climate interactions. In: HATFIELD, J.L.; STEWART, B.A. (Ed.). Crops residue management. Boca Raton: Lewis Publ., 1994. p.191-214. (Advances in Soil Science).

RICE, E.L. Allelophathy. 2.ed. New York: Academic Press, 1984. 422p.

RICE, K.J. Impacts of seed banks on grassland community structure and population dynamics. In: LECK, M.A.; PARKER, V.T.; SIMPSON, R.L. (Ed.). Ecology of soil seed banks. London: Academic Press, 1989. p.69-86.

ROBERTS, H.A. Seed banks in the soil. Advances in Applied Biology, v.6, p.1-55, 1981.

RODRIGUES, L.R. de A.; RODRIGUES, T. de J.D.; REIS, R.A. Alelopatia em plantas forrageiras. Jaboticabal: UNESP/FUNEP, 1992. 18p. (Boletim).

RODRIGUES, L.R. de A.; ALMEIDA, A.R.P. de; RODRÍGUEZ, T. de J.D. Alelopatia em plantas forrageiras e pastagens. In: SIMPÓSIO SOBRE ECOSSISTEMAS DE PASTAGENS, 2., Jaboticabal, SP, 1993. Anais. Jaboticabal, SP: FUNEP, 1993, p.100-129.

ROHRIG, M.; STULTZEL, H. A model for light competition between vegetable crops and weed. European Journal of Agronomy, v.14, p.13-29, 2001.

SALISBURY, F.B.; ROSS, C.W. Plant Physiology. Belmont: Wadsworth, 1991. 459p. 
SANCHEZ, O.J.F.; SALINAS, J.G. Comportamiento de ocho accesiones de Panicum maximum (Jacq.) en un oxisol de Carimagua, Colombia fertilizado con fosforo y calcio. Acta Agronomica, v.37, n.2, p.36-46, 1987.

SARRANTONIO, M.; SCOTT, T.W. Tillage effects on availability of nitrogen to corn following a winter green manure crop. Soil Science Society of America Journal, v.52, p.1661-8, 1998.

SCHREIBER, M.M. Influence of tillage, crop rotation, and weed management on giant foxtail (Setaria faberi) population dynamics and corn yield. Weed Science, v.40, p.645-653,1992.

SEEFELDT, S. S.; JENSEN, S. E.; FUERST, E. P. Log-logistic analysis of herbicide dose-response relationship. Weed Technology, v. 9, p.218-227, 1995.

SEVERINO, F.J. Efeitos de diferentes adubos verdes na supressão de plantas daninhas e seletividade de herbicidas. Piracicaba, 2000. 120p. Dissertação de (Mestrado)Escola Superior de Agricultura “Luiz de Queiroz”, Universidade de São Paulo.

SHELTON, H.M.; HUMPHREYS, L.R. Pasture establishment in upland rice crops at Na Pheng, Central Laos. Tropical Grassland, v.6, n.3, p.223-228, 1972.

SILVA, W. Interferência de Brachiaria brizantha sobre Eucalyptus citriodora e E. grandis, cultivados em solos com diferentes teores de água. Viçosa, 1997. 89p. Tese (Doutorado) - Universidade Federal de Viçosa. 
SILVA, A.A.; JAKELAITIS, A.; FERREIRA, L.R. Manejo de plantas daninhas no Sistema Integrado Agricultura-Pecuária. In: ZAMBOLIM, L.; SILVA, A.A.; AGNES, E.L. Manejo Integrado Integração Lavoura-Pecuária. Viçosa, MG, 2004. p.117-170.

SIMPSON, R.L.; LECK, M.A.; PARKER, V.T. Seed banks: General concepts and methodological issues. In: LECK, M.A.; PARKER, V.T.; SIMPSON, R.L. (Ed). Ecology of soil seed banks. London: Academic Press, 1989. p.3-8.

SKORA NETO, F. Efeito da prevenção de produção de sementes pelas plantas daninhas e da aplicação de herbicida em jato dirigido na densidade de infestação na cultura do milho em anos sucessivos. Planta Daninha, v.19, n.1, p.1-10, 2001.

SOUZA NETO, J.M. Época de plantio e adubação de Brachiaria brizantha cv. Marandu e espaçamento do milho como cultura acompanhante, na formação de pastagens. Piracicaba, 1993. 58p. Dissertação (Mestrado) - Escola Superior de Agricultura “Luiz de Queiroz”, Universidade de São Paulo.

STANIZIO, R.M.; LEITE, G.G.; VILELA, L. Efeito alelopático de Brachiaria brizantha cv. Marandu sobre o crescimento de plantas de quatro leguminosas forrageiras. In: REUNIÃO ANUAL DA SOCIEDADE BRASILEIRA DE ZOOTECNIA, 28., João Pessoa, PB, 1991. Anais. João Pessoa: SBZ, 1991. p.95.

TEASDALE, J.R. Cover crops, smother plants, and weed management. London: Arbor Press, 1998. p.247-270.

TEMPLETON, A.R.; LEVIN, D.A. Evolutionary consequences of seed pools. American Naturalist, v.114, p.232-249, 1979. 
TOLENAAR, M.; NISSANKA, S.P.; AGUILERA, A.; et al. Effect of weed interference and soil nitrogen on four maize hybrids. Agronomy Journal, v.86, p.596-601, 1994.

TRIPLETT, G.B. Crop management practices for surface tillage systems. In: SPAGUE, M.A.; TRIPLETT, G.B. (Ed.). No tillage and surface tillage agriculture: the tillage revolution. New York: John Wiley, 1986. p.149-182.

VAL, W.M.C. Efeito de restos culturais sobre o controle de plantas daninhas. Londrina: EMBRAPA-CNPSo, 1997. p.91-92 (Resultados de Pesquisa da EMBRAPA Soja, 1996).

VICTORIA FILHO, R. Estratégia de manejo de plantas daninhas. In : ZAMBOLIM, L. (Ed.). Manejo integrado - doenças, pragas e plantas daninhas. Viçosa: MG. Departamento de Fitopatologia, 2000, p.349-362.

VILELA, L.; MACEDO, M.C.M.; MARTHA JUNIOR, G.B.; KLUTHCOUSKI, J. Benefícios da integração agricultura-pecuária. In: KLUTHCOUSKI, J.; STONE, L.F.; AIDAR, H. (Ed.). Integração lavoura-pecuária. Santo Antonio de Goiás: Embrapa Arroz e Feijão. 2003. p.143-169.

VOLL, E.; GAZZIERO, D.L.P. Resultados de levantamento de bancos de sementes e de flora daninha emergente, no manejo integrado de plantas daninhas em lavoura de soja, no Paraná, em 1995/96. EMBRAPA-CNPSo, Londrina: (Resultados de Pesquisa da EMBRAPA Soja, 1996). 1997. p.92-96. 
VOGTMAnN, H.; WAGNER, R. Agricultura ecológica - teoria \& prática. Porto Alegre: Mercado Aberto, 1987. 168p.

WALLACE, J.S.; BARCHELOR, C.H.; DABEESING, D.N.; et al. Comparision of the interception and water use of plants and first ratoon sugar cane intercropped with maize. Agricultural and Forest Meteorology, v.57, p.85-105, 1991.

WILKINSON, S.R.; DEVINE, O.J.; BELESKY, J.W. et al. No-tillage intercropped corn production in tall fescue sod as affected by sod control and nitrogen fertilization. Agronomy Journal. v.79, p.685-690, 1987.

WILLEY, R.W. Intercropping - Its importance and research needs. Part. 1. Competition and Yield advantages. Field Crops Abstracts, v.42, n.1, p.1-10. 1979.

WILSON, J.B. Shoot competition and root competition. Journal of Applied Ecology, v.25, n.2, p.279-296, 1988.

WITTAKER, R.H.; FEENY, P.P. Allelochemics: Chemical interaction between species. Science, v.171, p.757-770, 1971.

WUTKE, E.B. Adubação verde: manejo da fitomassa e espécies utilizadas no Estado de São Paulo. In: WUTKE, E. B.; BULISANI, E. A.; MASCARENHAS, H. A. I Curso sobre adubação verde no IAC. Campinas: IAC. 1993. p.17-30. (Documentos IAC 35).

WUTKE, E.B. Desempenho do feijoeiro em rotação com milho e adubos verdes. Piracicaba, 1998. 146p. Tese de (Doutorado)-Escola Superior de Agricultura "Luiz de Queiroz”, Universidade de São Paulo. 
ZAGONEL, J.; VENANCIO, W.S.; KUNZ, R. Efeitos de métodos e épocas de controle das plantas daninhas na cultura do milho. Planta Daninha, v.18, n.1, p.143-150, 2000 . 